\title{
Geochemistry and Petrology of Oligocene and Miocene Ash-Flow Tuffs of the Southeastern Great Basin, Nevada
}

U.S. GEOLOGICAL SURVEY PROFESSIONAL PAPER 1559




Instructions on ordering publications of the U.S. Geological Survey, along with prices of the last offerings, are given in the current-year issues of the monthly catalog "New Publications of the U.S. Geological Survey." Prices of available U.S. Geological Survey publications released prior to the current year are listed in the most recent annual "Price and Availability List." Publications that may be listed in various U.S. Geological Survey catalogs (see back inside cover) but not listed in the most recent annual "Price and Availability List" may no longer be available.

Reports released through the NTIS may be obtained by writing to the National Technical Information Service, U.S. Department of Commerce, Springfield, VA 22161; please include NTIS report number with inquiry.

Order U.S. Geological Survey publications by mail or over the counter from the offices listed below.

\section{BY MAIL}

\section{Books}

Professional Papers, Bulletins, Water-Supply Papers, Techniques of Water-Resources Investigations, Circulars, publications of general interest (such as leaflets, pamphlets, booklets), single copies of Earthquakes \& Volcanoes, Preliminary Determination of Epicenters, and some miscellaneous reports, including some of the foregoing series that have gone out of print at the Superintendent of Documents, are obtainable by mail from

\section{U.S. Geological Survey, Map Distribution Box 25286, MS 306, Federal Center Denver, CO 80225}

Subscriptions to periodicals (Earthquakes \& Volcanoes and Preliminary Determination of Epicenters) can be obtained ONLY from the

\section{Superintendent of Documents Government Printing Office Washington, DC 20402} Documents.)

(Check or money order must be payable to Superintendent of Maps

For maps, address mail orders to

\section{U. S. Geological Survey, Map Distribution Box 25286, Bldg. 810, Federal Center Denver, CO 80225}

Residents of Alaska may order maps from

\author{
U.S. Geological Survey, Earth Science Information Center \\ 101 Twelfth Ave., Box 12 \\ Fairbanks, AK 99701
}

\section{OVER THE COUNTER}

\section{Books and Maps}

Books and maps of the U.S. Geological Survey are available over the counter at the following U.S. Geological Survey offices, all of which are authorized agents of the Superintendent of Documents.

- ANCHORAGE, Alaska-Rm. 101, 4230 University Dr.

- LAKEWOOD, Colorado-Federal Center, Bldg. 810

- MENLO PARK, California-Bldg. 3, Rm. 3128, 345 Middlefield Rd.

- RESTON, Virginia-USGS National Center, Rm. 1C402, 12201 Sunrise Valley Dr.

- SALT LAKE CITY, Utah-Federal Bldg., Rm. 8105, 125 South State St.

- SPOKANE, Washington-U.S. Post Office Bldg., Rm. 135, West 904 Riverside Ave.

- WASHINGTON, D.C.-Main Interior Bldg., Rm. 2650, 18th and C Sts., NW.

\section{Maps Only}

Maps may be purchased over the counter at the following U.S. Geological Survey offices:

- FAIRBANKS, Alaska-New Federal Bldg, 101 Twelfth Ave.

- ROLLA, Missouri-1400 Independence Rd.

- STENNIS SPACE CENTER, Mississippi-Bldg. 3101 


\section{Geochemistry and Petrology of Oligocene and Miocene Ash-Flow Tuffs of the Southeastern Great Basin, Nevada}

By Edward A. du Bray

U.S. GEOLOGICAL SURVEY PROFESSIONAL PAPER 1559

Compositional characterization and evaluation of geochemical zonation in ash-flow tuffs of the



White River Narrows area 


\title{
U.S. DEPARTMENT OF THE INTERIOR BRUCE BABBITT, Secretary
}

\author{
U.S. GEOLOGICAL SURVEY
}

Gordon P. Eaton, Director

For sale by U.S. Geological Survey, Information Services

Box 25286, Federal Center

Denver, CO 80225 Any use of trade, product, or firm names in this publication is for descriptive purposes only and
does not imply endorsement by the U.S. Government

\section{Library of Congress Cataloging-in-Publication Data}

du Bray, E. A.

Geochemistry and petrology of Oligocene and Miocene ash-flow tuffs of the southeastern Great Basin, Nevada / by Edward A. du Bray.

p. cm.-(U.S. Geological Survey professional paper ; 1559)

Includes bibliographical references.

Supt. of Docs. no.: I 19.16: 1559

1. Volcanic ash, tuff, etc.-Nevada. 2. Geology, Stratigraphic-

Oligocene. 3. Geology, Stratigraphic-Miocene. 4. Geochemistry-

Nevada. 5. Geology-Nevada. I. Title. II. Series.

QE461.D8 1994

$552^{\prime} .23^{\prime} 097931-\mathrm{dc} 20$ 


\section{CONTENTS}



\section{FIGURES}

1. Index map showing location of White River Narrows area and of ash-flow tuff composition profiles.................... 2

2. Total alkali-silica variation diagram for ash-flow tuffs, White River Narrows area ............................................... 6

3-8. Photographs showing:

3. Outcrops of Lund Formation, Petroglyph Cliff Ignimbrite, Monotony Tuff, and Baldhills Member of the Isom Formation in cliffs north of White River Narrows.

4. Outcrops of continuous section from Baldhills up through Hole-in-the-Wall Members of the

Isom Formation between Lund and Leach Canyon Formations.

5. Upper part of section between Lund and Leach Canyon Formations

6. Tuff of Hancock Summit, upper cooling unit of the Shingle Pass Tuff, Hole-in-the-Wall Member of the Isom Formation, Leach Canyon Formation, Swett Tuff Member, Bauers Tuff Member, and Pahranagat

Formation

. Uppermost part of upper cooling unit of the Narrows Member of the Leach Canyon Formation, Swett Tuff

Member, Bauers Tuff Member, and base of Pahranagat Formation

Uppermost part of the upper cooling unit of the Narrows Member of the Leach Canyon Formation, Swett

Tuff Member, Bauers Tuff Member, Pahranagat Formation, and Harmony Hills Tuff

9. Variation diagrams showing abundances of selected major oxides and trace elements in ash-flow tuffs, White

River Narrows area

10. Trace element-tectonic setting discrimination variation diagrams showing average compositions of ash-flow tuffs, White River Narrows area

1. Ternary AFM diagram showing compositions of ash-flow tuffs, White River Narrows area

12. Variation diagram showing average rubidium and strontium abundances in ash-flow tuffs, White River Narrows area .

13. Ternary variation diagram showing average relative proportions of rubidium, barium, and strontium in ash-flow tuffs, White River Narrows area

14. Chondrite-normalized extended trace-element diagram showing average compositions of ash-flow tuffs, White River Narrows area....

15. Chondrite-normalized rare earth element diagram showing average compositions of ash-flow tuffs, White River Narrows area.

16. Diagrams showing stratigraphic compositional variation of ash-flow tuffs, White River Narrows area

17. Diagrams showing enrichment-depletion factors calculated from compositions of stratigraphically lowest and highest samples in composition profiles for ash-flow tuffs, White River Narrows area 
18. Histogram showing enrichment-depletion abundance behavior of oxides and elements in samples from composition profiles of the ash-flow tuffs, White River Narrows area

19. Histogram showing within-unit enrichment-depletion abundance behavior of oxides and elements in composition profile sample suites of ash-flow tuffs, White River Narrows area

20. Variation diagrams showing compositions of samples in the stratigraphic interval between the Baldhills and Hole-in-the Wall Members of the Isom Formation

\section{TABLES}

1. Age, approximate average thickness, and location of systematically, vertically sampled sections of ash-flow tuffs in the White River Narrows area

2. Summary of petrographic characteristics of ash-flow tuffs in the White River Narrows area.....

3. Chemical composition of samples from composition profiles of middle Tertiary ash-flow tuffs in the Seaman Range

4. Chemical compositions of middle Tertiary ash-flow tuffs in the White River Narrows area

5. Average major oxide, CIPW normative, and trace-element compositions of middle Tertiary ash-flow tuffs in the Seaman Range

6. Summary of enrichment and depletion relations for ash-flow tuff units exposed in the Seaman Range 


\title{
Geochemistry and Petrology of Oligocene and Miocene Ash-Flow Tuffs of the Southeastern Great Basin, Nevada
}

\author{
By Edward A. du Bray
}

ABSTRACT

A composite stratigraphic section in the White River Narrows area of southeastern Nevada contains 18 regionally distributed middle Tertiary dacite to rhyolite ash-flow tuffs erupted from several caldera sources within subductionrelated volcanic fields of the Great Basin in western North America. Geochemical data for these tuffs provide an excellent opportunity to study stratigraphic and petrologic relations of voluminous middle Tertiary ash-flow tuffs erupted from three major caldera complexes in the southeastern part of the Great Basin. Chemical data for each of these tuffs are distinctive and provide a significant addition to petrographic, stratigraphic, geochronologic, and paleomagnetic data used to identify and correlate these units. The compositional range defined by these ash-flow tuffs is relatively limited.

Vertical geochemical zonation in source magma reservoirs, as deduced from compositional data from systematically collected stratigraphic sections, is distinct from, though generally similar to, that described for some high-silica rhyolite systems, such as the Bishop Tuff. The sense of vertical enrichment and depletion for many oxides and elements is inconsistent among the various stratigraphic units; in addition, the magnitudes of enrichments and depletions are significantly smaller than those described for other high-silica rhyolite systems. Only the abundances of $\mathrm{SiO}_{2}$, rubidium, tantalum, and cesium systematically decrease upsection within each of the studied ash-flow tuffs, and only the abundances of $\mathrm{CaO}$, cobalt, iron, and strontium systematically increase upsection. Variability in the sense and magnitude of enrichments and depletions in the ash-flow tuffs in the White River Narrows area suggests that no single process is responsible for evolution of these magmas. Crystal fractionation involving variable mineral assemblages may be the principal process that controlled development of the geochemical zonation portrayed by these tuffs.

\section{INTRODUCTION}

Middle Tertiary volcanic rocks in the Great Basin are generally similar to those in large, well-studied middle
Tertiary volcanic fields, including the San Juan, Marysvale, and Mogollon-Datil, in western North America. Knowledge of middle Tertiary volcanic rocks in large parts of the Great Basin is relatively incomplete, however, and a number of major stratigraphic and petrogenetic questions remain unanswered.

The White River Narrows area, termed an "outflow alley" by Best and others (1993) because of remarkably complete preservation of Oligocene and Miocene ash-flow tuffs in the area, is in the overlap zone between three of the largest caldera complexes (Indian Peak, Central Nevada, and Caliente) in the southeastern Great Basin and therefore provides an excellent opportunity to study stratigraphic relations and petrologic evolution associated with voluminous middle Tertiary magmatism. Geochemical characteristics and interpretations presented here for tuffs of the White River Narrows area are probably applicable to distributions of these tuffs throughout the southeastern Great Basin. Furthermore, because the tuffs exposed in the White River Narrows area represent a major component of magma erupted from middle Tertiary sources in this area, their geochemistry exemplifies that of middle Tertiary magmatism throughout the southeastern Great Basin.

In the Seaman Range (fig. 1), about $180 \mathrm{~km}$ north of Las Vegas, the White River Narrows area (hereafter referred to as the Narrows area) is centrally located within the province affected by voluminous middle Tertiary ashflow eruption (Best, Christiansen, and others, 1989). Complete stratigraphic sections of all but the oldest and youngest of 18 middle Tertiary, outflow-facies ash-flow tuffs are present in the Narrows area (Hurtubise and du Bray, 1992). Age, approximate average thickness, and stratigraphic relations for ash-flow tuffs exposed in the Narrows area are summarized in table 1.

The majority of the igneous rocks exposed in the Great Basin are ash-flow tuffs (Best, Christiansen, and others, 1989) whose origins are related to arc magmatism associated with Cenozoic subduction along the western margin of North America (Christiansen and Lipman, 1972; Lipman and others, 1972; Lipman, 1980; Johnson, 1991; Ward, 1991). Studies by Mackin (1960), Cook (1965), and Williams (1967) provide the earliest stratigraphic and petrographic descriptions of these 


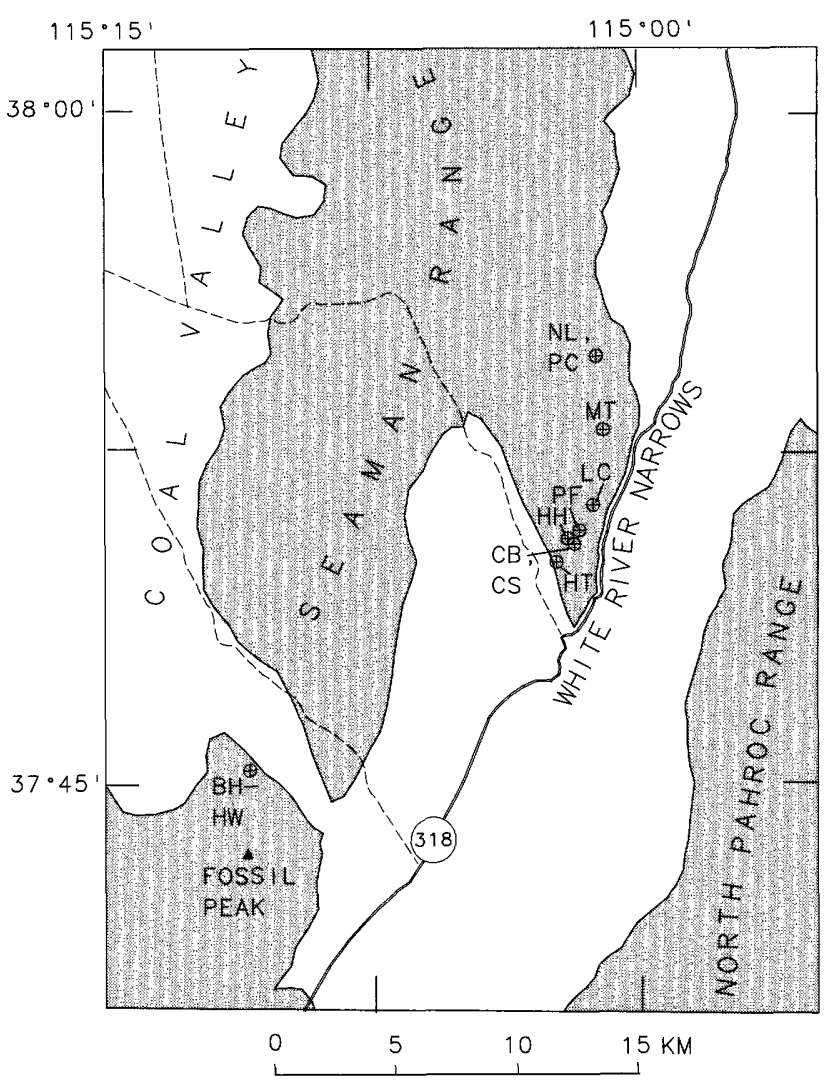

Figure 1. Index map showing location of the White River Narrows area and locations of ash-flow tuff composition profiles. Shaded areas show the distribution of the indicated mountain ranges. Unit designations: NL, PC, Lund Formation and Petroglyph Cliff Ignimbrite (southeast and northwest parts of profile, respectively); MT, Monotony Tuff; LC, lower and upper cooling units of the Leach Canyon Formation (southeast and northwest parts of profile, respectively); PF, Pahranagat Formation; $\mathrm{HH}$, Harmony Hills Tuff; CS, CB, Swett and Bauers Tuff Members of the Condor Canyon Formation (southeast and northwest parts of profile, respectively); HT, Hiko Tuff; BH-HW, Baldhills Member of the Isom Formation, lower and intermediate cooling units of the Shingle Pass Tuff, tuffs of the Golden Gate Range and Hancock Summit, upper cooling unit of the Shingle Pass Tuff, and the Hole-in-the-Wall Member of the Isom Formation (southeast through northwest parts of the profile, respectively).

rocks. During the 1960's, Ekren and others $(1971,1977)$ added considerably to the understanding of volcanic rocks in the southwestern and south-central parts of the Great Basin. Anderson and Rowley (1975) and Rowley and others (1979) described stratigraphic and lithologic features of Great Basin ash-flow tuffs that extend into southwestern Utah. Best, Christiansen, and others (1989) summarized knowledge concerning middle Tertiary volcanic rocks of the Great Basin. The most recent syntheses and presentations of new geochronologic, petrographic, paleomagnetic, and stratigraphic data for tuffs of southeastern Nevada are those of Best and others (1993), Rowley and others (in press), and Scott and others (in press).
Geologic mapping (du Bray and Hurtubise, 1994) demonstrates that the ash-flow tuff section in the Narrows area is remarkably complete. A composite section of the 18 units, compiled from numerous individual sections in the area (fig. 1), contains no obvious erosional intervals and very minor interbedded sedimentary deposits. The majority of the individual sections is in the White River Narrows (fig. 1), an area that has been recognized since Cook's (1965) work as containing the most complete section of middle Tertiary ashflow tuffs in the southeastern Great Basin.

The chemical compositions of tuffs in the Narrows area are distinctive. Compositional data, especially for trace elements, can be combined with petrographic (Mackin, 1960; Williams, 1960, 1967; Cook, 1965), stratigraphic (Best, Christiansen, and others, 1989; Rowley and others, in press; Scott and others, in press), paleomagnetic (Gromme and others, 1972; Scott and others, in press), and geochronologic (Armstrong, 1970; Deino and Best, 1988; Best, Christiansen, and others, 1989; Best and others, 1993; Rowley and others, in press; Scott and others, in press) data to identify and correlate ash-flow tuffs in the southeastern part of the Great Basin where stratigraphic problems are unresolved.

Vertical compositional zonation within each of the tuffs in the Narrows area differs from that documented for other high-silica rhyolite ash-flow tuffs. The observed zonations are discontinuous and variable with regard to whether particular elements are concentrated in their early- versus lateerupted parts; enrichment-depletion factors are smaller than those documented for high-silica rhyolite tuffs studied by Smith (1979) and Hildreth (1979). The nature and extent of these differences may indicate that magma reservoirs represented by tuffs of the Narrows area became compositionally zoned by fractionation of distinctive sets and proportions of minerals. The evolution of vertical compositional zonation must be carefully evaluated. Zonation probably does not derive from a unique, universally operative process but rather from various processes in different magma reservoirs.

The availability of a large, well-documented body of compositional data for the tuffs of the Narrows area enables its comparison with data for other volcanic rocks of the Great Basin (Gans and others, 1989; Best and Christiansen, 1991; Feeley and Grunder, 1991) and with data for other major middle Tertiary volcanic fields of southwestern North America. Time-space-composition comparisons of this type may help refine interpretations of the plate tectonic processes (Johnson, 1991; Ward, 1991) that produced the major, middle Tertiary volcanic fields of southwestern North America.

Acknowledgments.-This study is an outgrowth of a mineral resource assessment of the U.S. Bureau of Land Management Weepah Spring Wilderness Study Area. I am indebted to P.D. Rowley, D.A. Sawyer, W.A. Duffield, and M.G. Best whose incisive reviews helped improve the focus and enhance interpretive sections in early drafts of the manuscript. 
Table 1. Age, approximate average thickness, and Iocation of systematically, vertically sampled sections of ash-flow tuffs in the White River Narrows area, Nevada.

[Units are arranged in stratigraphic order; youngest units are at the top of table. Unit designations as used in figures are given in parentheses]

\begin{tabular}{|c|c|c|c|c|c|c|}
\hline \multirow[b]{2}{*}{ Unit } & \multirow{2}{*}{$\begin{array}{c}\text { Isotopic } \\
\text { age (Ma) }{ }^{1}\end{array}$} & \multirow{2}{*}{$\begin{array}{l}\text { Thickness } \\
\text { (meters) }\end{array}$} & \multicolumn{4}{|c|}{ Location of composition profile } \\
\hline & & & \multicolumn{2}{|c|}{ Base } & \multicolumn{2}{|c|}{ Top } \\
\hline Hiko Tuff (HT) & 18.6 & 15 & $37^{\circ} 49^{\prime} 51^{\prime \prime}$ & $115^{\circ} 02^{\prime} 14^{\prime \prime}$ & $37^{\circ} 49^{\prime} 54^{\prime \prime}$ & $115^{\circ} 02^{\prime} 15^{\prime \prime}$ \\
\hline Pahranagat Formation (PF) & 22.65 & 15 & $37^{\circ} 50^{\prime} 36^{\prime \prime}$ & $115^{\circ} 01^{\prime} 38^{\prime \prime}$ & $37^{\circ} 50^{\prime} 37^{\prime \prime}$ & $115^{\circ} 01^{\prime} 40^{\prime \prime}$ \\
\hline \multicolumn{7}{|l|}{ Condor Canyon Formation } \\
\hline Bauers Tuff Member (CB) & 22.78 & 25 & $37^{\circ} 50^{\prime} 18^{\prime \prime}$ & $115^{\circ} 01^{\prime} 48^{\prime \prime}$ & $37^{\circ} 50^{\prime} 23^{\prime \prime}$ & $115^{\circ} 01^{\prime} 49^{\prime \prime}$ \\
\hline Upper cooling unit (LCU) & & & $37^{\circ} 51^{\prime} 03^{\prime \prime}$ & $115^{\circ} 01^{\prime} 14^{\prime \prime}$ & $37^{\circ} 51^{\prime} 08^{\prime \prime}$ & $115^{\circ} 01^{\prime} 20^{\prime \prime}$ \\
\hline Lower cooling unit (LCL) & & & $37^{\circ} 51^{\prime} 02^{\prime \prime}$ & $115^{\circ} 01^{\prime} 13^{\prime \prime}$ & $37^{\circ} 51^{\prime} 03^{\prime \prime}$ & $115^{\circ} 01^{\prime} 14^{\prime \prime}$ \\
\hline Hole-in-the Wall Member of the Isom Formation (HW) & & 15 & $37^{\circ} 45^{\prime} 15^{\prime \prime}$ & $115^{\circ} 10^{\prime} 56^{\prime \prime}$ & $37^{\circ} 45^{\prime} 16^{\prime \prime}$ & $115^{\circ} 10^{\prime} 58^{\prime \prime}$ \\
\hline Shingle Pass Tuff, upper cooling unit (SPU) & 26.0 & 70 & $37^{\circ} 45^{\prime} 13^{\prime \prime}$ & $115^{\circ} 10^{\prime} 51^{\prime \prime}$ & $37^{\circ} 45^{\prime} 15^{\prime \prime}$ & $115^{\circ} 10^{\prime} 56^{\prime \prime}$ \\
\hline Tuff of Hancock Summit (HS) & $?$ & 45 & $37^{\circ} 45^{\prime} 12^{\prime \prime}$ & $115^{\circ} 10^{\prime} 48^{\prime \prime}$ & $37^{\circ} 45^{\prime} 13^{\prime \prime}$ & $115^{\circ} 10^{\prime} 51^{\prime \prime}$ \\
\hline Baldhills Tuff Member of Isom Formation (BH) & 27.0 & 2 & $37^{\circ} 45^{\prime} 08^{\prime \prime}$ & $115^{\circ} 10^{\prime} 37^{\prime \prime}$ & $37^{\circ} 45^{\prime} 08^{\prime \prime}$ & $115^{\circ} 10^{\prime} 37^{\prime \prime}$ \\
\hline Monotony Tuff (MT) & 27.31 & 60 & $37^{\circ} 5250^{\prime \prime}$ & $115^{\circ} 00^{\prime} 58^{\prime \prime}$ & $37^{\circ} 5254^{\prime \prime}$ & $115^{\circ} 01^{\prime} 11^{\prime \prime}$ \\
\hline Petroglyph Cliff Ignimbrite (PC) & $27.6 \pm$ & 10 & $37^{\circ} 5428^{\prime \prime}$ & $115^{\circ} 01^{\prime} 05^{\prime \prime}$ & $37^{\circ} 5428^{\prime \prime}$ & $115^{\circ} 01^{\prime} 08^{\prime \prime}$ \\
\hline \multicolumn{7}{|l|}{ Needles Range Group } \\
\hline Lund Formation (NL) & 27.9 & 40 & $37^{\circ} 5429^{\prime \prime}$ & $115^{\circ} 01^{\prime} 02^{\prime \prime}$ & $37^{\circ} 5428^{\prime \prime}$ & $115^{\circ} 01^{\prime} 05^{\prime \prime}$ \\
\hline Wah Wah Springs Formation (NW) & $\sim 30$ & 20 & -- & -- & -- & -- \\
\hline
\end{tabular}

${ }^{1}$ See text for sources of ages.

\section{STRATIGRAPHY OF ASH-FLOW TUFFS IN THE NARROWS AREA}

Middle Tertiary ash-flow eruptions resulted in numerous calderas in the Great Basin; locations, products, and ages of these calderas are summarized by Best, Christiansen, and others (1989, fig. 7, table 2). These tuffs were derived from sources in one of three caldera complexes: the Indian Peak caldera complex -Wah Wah Springs and Lund Formations and the Baldhills and Hole-in-the-Wall Members of the Isom Formation; the Central Nevada caldera complex-Monotony and Shingle Pass Tuffs, tuff of the Golden Gate Range, tuff of Hancock Summit, and Pahranagat Formation; and the Caliente caldera complex-Leach Canyon and Condor Canyon Formations and Harmony Hills and Hiko Tuffs. The oldest and youngest tuffs of the Narrows area are the $\sim 30-\mathrm{Ma}$ Wah Wah Springs Formation (Best and others, 1993) and the 18.6-Ma Hiko Tuff (Taylor and others, 1989) (table 1). Stratigraphic relations and important features of the tuffs of the Narrows area, from oldest to youngest, are described following; petrographic attributes are summarized in table 2 .

The oldest ash-flow tuffs in the Narrows area are part of the Oligocene Needles Range Group (Best and Grant, 1987), named for exposures in the Needles Range of western Utah and deposited on an undulating surface of Paleozoic carbonate rocks. The Cottonwood Wash Tuff, Wah Wah Springs Formation, and Lund Formation of the Needles Range Group have a total volume of at least $6,600 \mathrm{~km}^{3}$ and were successively erupted from the nested Indian Peak caldera complex (Best and Grant, 1987; Best, Christiansen, and Blank, 1989). Small and major amounts, respectively, of the $~ 30-M a$ Wah Wah Springs (Best and others, 1993) and the 27.9-Ma Lund Formations (Best and Grant, 1987) are present in the Narrows area; both tuffs are dacite (fig. 2). The Wah Wah Springs, the only tuff in the Great Basin that contains more hornblende than biotite (Best and others, 1993), forms limited outcrops along the east flank of the Seaman Range; the tuff probably wedges out in the subsurface west of these outcrops. The Lund Formation forms massive outcrops throughout the Seaman Range (fig. 3) and is particularly well exposed north of White River Narrows (du Bray and Hurtubise, 1994).

The Petroglyph Cliff Ignimbrite (fig. 3) of Cook (1965) is a lithic-rich dacite ash-flow tuff (fig. 2). The uppermost part of this tuff contains distinctive subangular, black glass lapilli $(20 \mathrm{~cm})$. The unit, whose source caldera is unknown, is about $15 \mathrm{~m}$ thick. The Petroglyph Cliff Ignimbrite is not exposed at Cook's (1965) type section, though it is well exposed a few kilometers to the north (du Bray and Hurtubise, 1994); the Baldhills Member of the Isom Formation, similar in appearance to the Petroglyph Cliff Ignimbrite, is 







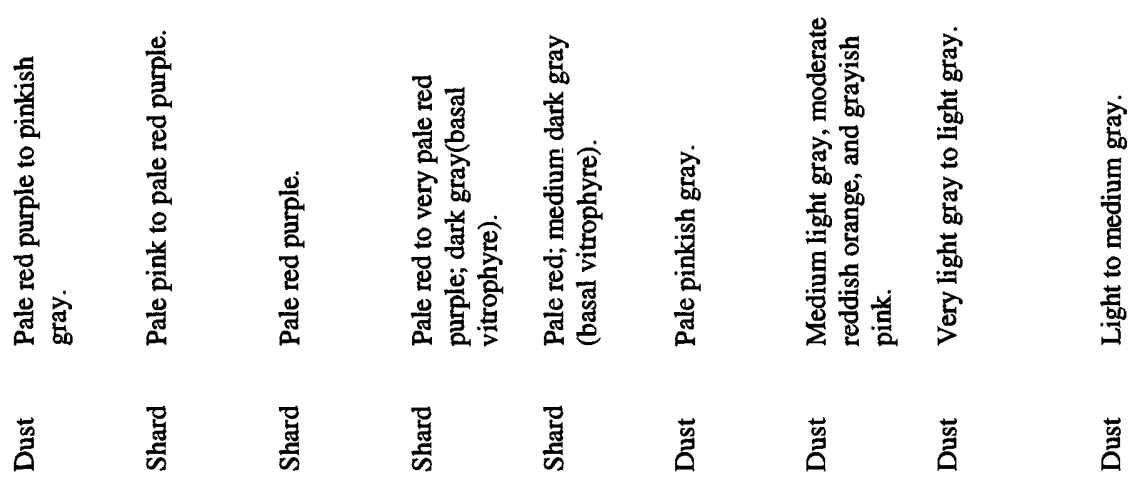

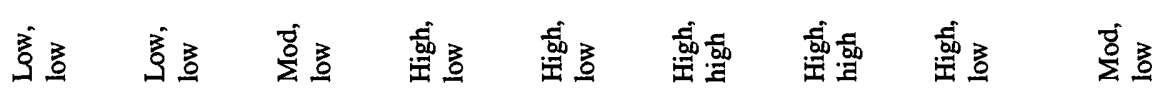

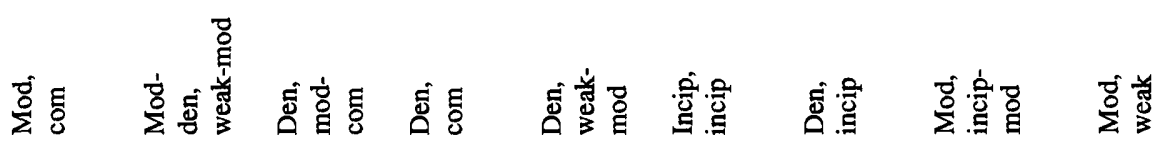



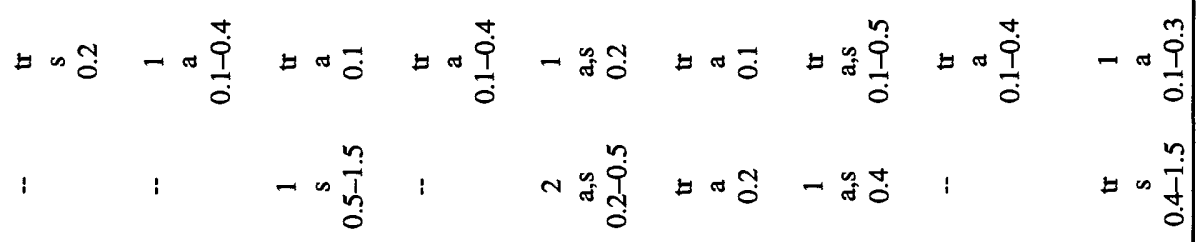

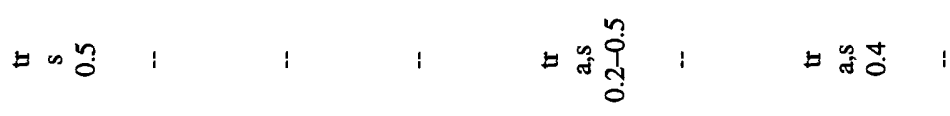

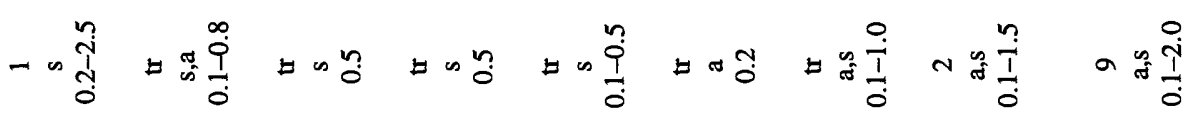

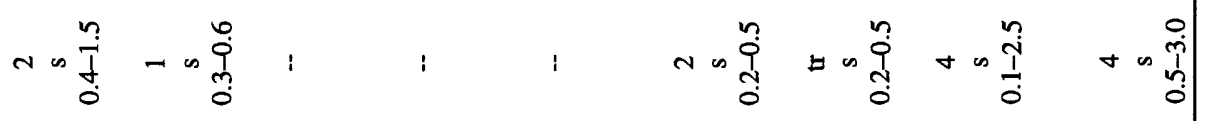

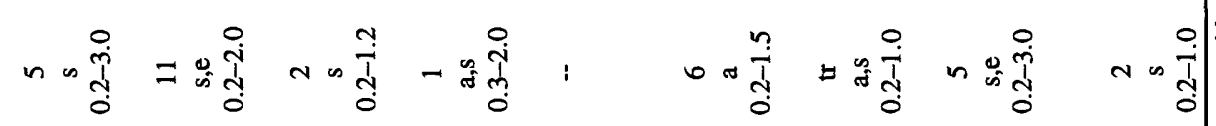

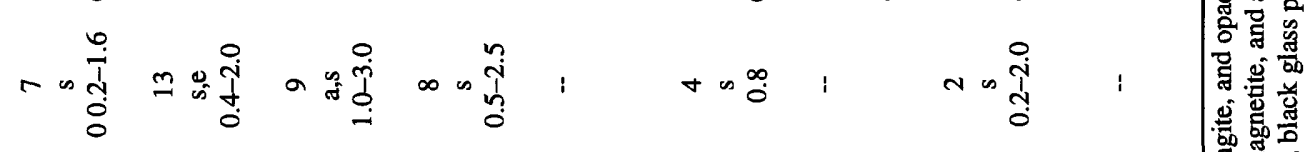



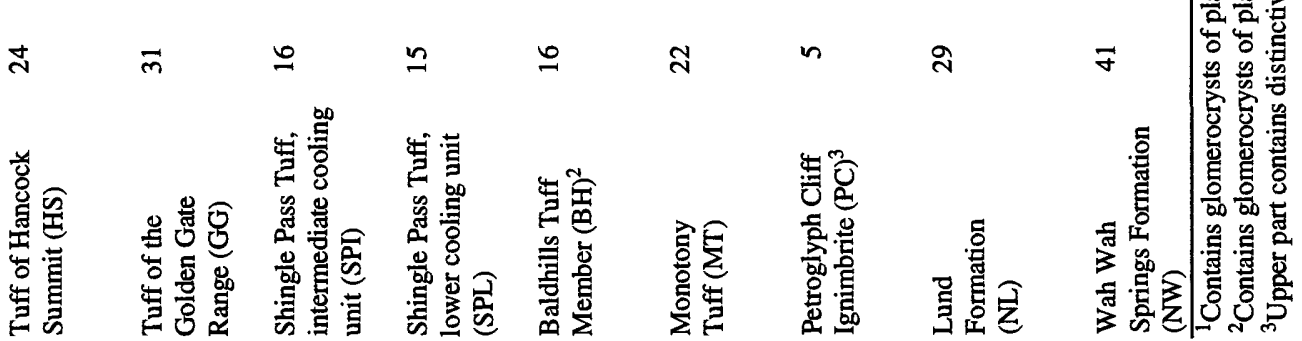





Figure 2. Total alkali-silica variation diagram for ash-flow tuffs in the White River Narrows area. International Union of Geological Sciences classification grid (Le Bas and others, 1986) is also shown. Unit designations identify symbols used in all subsequent figures: NW, Wah Wah Springs Formation; NL, Lund Formation; PC, Petroglyph Cliff Ignimbrite; MT, Monotony Tuff; BH, Baldhills Member of the Isom Formation; SPL and SPI, lower and intermediate cooling units, respectively, of the Shingle Pass Tuff; GG, tuff of the Golden Gate Range; HS, tuff of Hancock Summit; SPU, upper cooling unit of the Shingle Pass Tuff; HW. Hole-in-the-Wall Member of the Isom Formation; LCL and LCU, lower and upper cooling units of the Leach Canyon Formation, respectively; CS and CB, Swett Tuff and Bauers Tuff Members of the Condor Canyon Formation, respectively; PF, Pahranagat Formation; HH, Harmony Hills Tuff; HT, Hiko Tuff. A, Averages (from table 5) of compositions for ash-flow tuffs in the Narrows area, Nevada. $B$, Composition ranges (from tables 3 and 4) for ash-flow tuffs exposed in the Narrows area. instead exposed at the designated type section. The phenocrysts, composition, and dense welding of the Petroglyph Cliff Ignimbrite are similar to those of Isom-compositionaltype tuffs of Best, Christiansen, and others (1989). Although the age of the Petroglyph Cliff has not been determined, its eruption is bracketed between 27.9 and $27.31 \mathrm{Ma}$, the ages of the underlying Lund Formation and overlying Monotony Tuff, respectively.

The Monotony Tuff is a pumiceous, dacite to rhyolite ash-flow tuff (fig. 2, tables 2, 3) that forms recessive-weathering outcrops (fig. 3 ). In the Narrows area, the Monotony Tuff is exposed in a north-trending belt several kilometers wide that extends from about $5 \mathrm{~km}$ south of White River Narrows to about $10 \mathrm{~km}$ south of Black Cliff. Best, Christiansen, and others (1989) reported an ${ }^{40} \mathrm{Ar} /{ }^{39} \mathrm{Ar}$ age of $27.3 \mathrm{Ma}$ for the Monotony. In most places, the Monotony probably is composed of a single, thick ash-flow cooling unit. Ekren and others (1971) suggested that the Monotony was derived from a source in the southern Pancake Range, whereas Best, Christiansen, and others (1989) and Best and others (1993) suggested a source within the Central Nevada caldera complex.

Rocks above the Needles Range Group and the Monotony Tuff and below the Leach Canyon Formation were termed the Pahrock sequence by Cook (1965). In the Narrows area, seven lithologically similar ash-flow tuffs crop out in this interval (figs. 4-6). These units, informally described as units 1-7, from oldest to youngest, of the rhyolite tuffs of the Seaman Range (Hurtubise and du Bray, 1992) are correlated with more widely distributed ash-flow tuffs. Deposition and preservation of all tuffs in this interval, initially identified on the basis of compositional data presented herein, are rare; a complete section is present about $1.5 \mathrm{~km}$ north of Fossil Peak (figs. 1, 4, 5). The section exposed in the Narrows area is anomalously thin and includes only a few of the ash-flow tuffs known to be in this interval.

In the northern cliffs of White River Narrows the Monotony Tuff is overlain by the Baldhills Member of the Isom Formation. This erosion-resistant tuff is a trachydacitic, 1-2-m-thick black vitrophyre (fig. 2) erupted $27.0 \mathrm{Ma}$ from a probable source in the Indian Peak caldera complex (Best and others, 1993). The Baldhills, another Isom-compositional type tuff (Best, Christiansen, and others, 1989), may also be correlative with the 27.4-Ma tuff of Hamilton Spring (Taylor and others, 1989). Stratigraphically above the Bald Hills are six rhyolite ash-flow tuffs (fig. 2) that form both massive bouldery outcrops and subordinate recessive intervals. Petrographic and compositional data suggest that the first two of these tuffs are the lower and intermediate cooling units of the Shingle Pass Tuff, which Sargent and Houser (1970) suggest was erupted from the Quinn Canyon caldera; Best and others (1993) reported ages of $26.7 \mathrm{Ma}$ and 26.4-26.5 Ma, respectively, for these tuffs. M.G. Best (oral commun., 1989) suggested that the next three tuffs in this ascending stratigraphic sequence are correlative with the tuff of the Golden Gate Range, with the tuff of Hancock Summit 


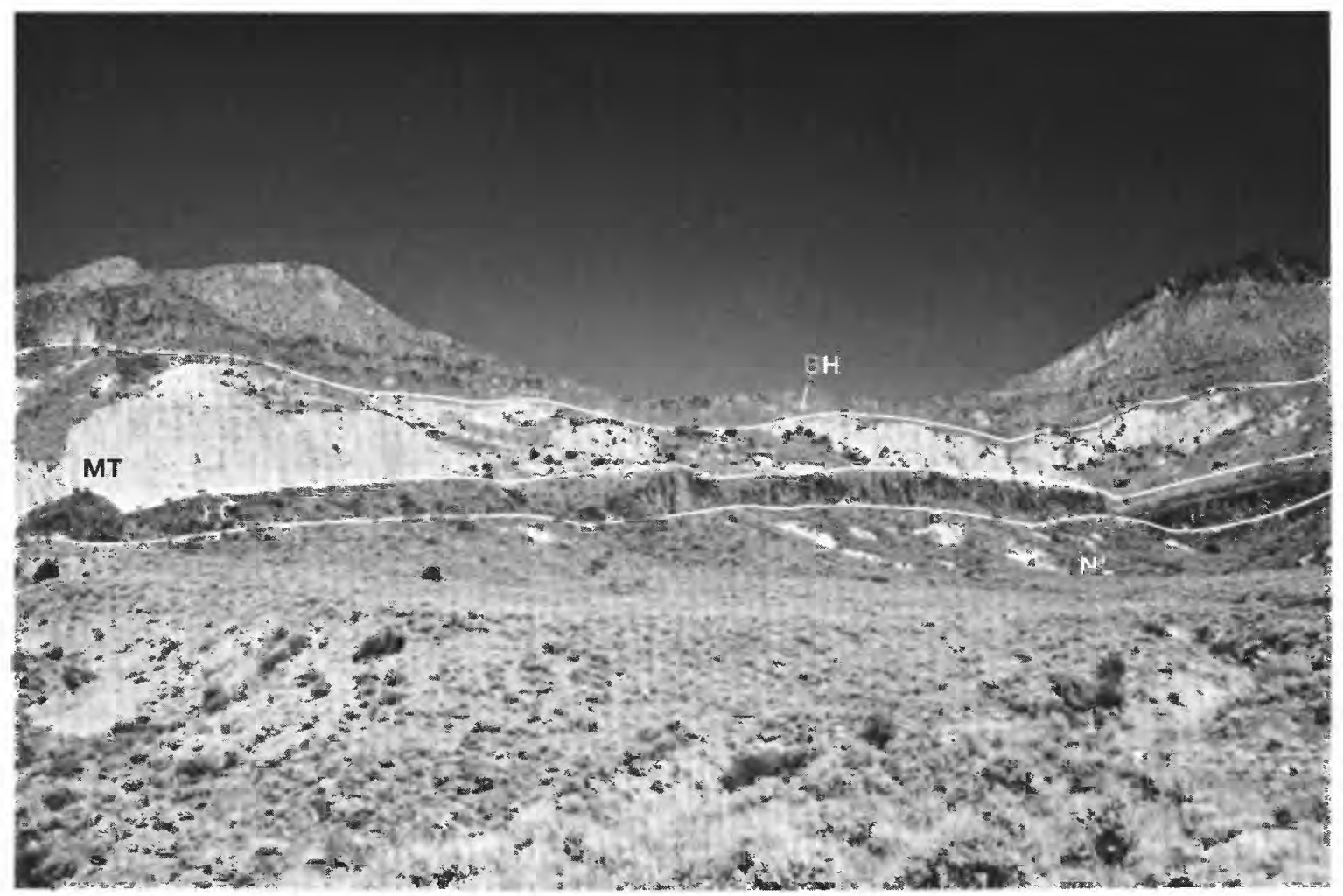

Figure 3. Outcrops of the Lund Formation (NL), Petroglyph Cliff Ignimbrite (PC), Monotony Tuff (MT), and the Baldhills Member (BH) of the Isom Formation in cliffs north of White River Narrows. View to the west.

(Best, Christiansen, and others, 1989), whose inferred source is an unnamed caldera $85 \mathrm{~km}$ west-northwest of Caliente, Nev., and with the 26.0-Ma upper cooling unit of the Shingle Pass Tuff (Best and others, 1993), respectively. The youngest of the tuffs beneath the Leach Canyon Formation is another Isom-compositional-type tuff (Best, Christiansen, and others, 1989) and is probably correlative with the Hole-in-theWall Member of the Isom Formation (Best and others, 1993).

The type locality of the 23.8-Ma Leach Canyon Formation (Best and others, 1993), the next youngest tuff in the Narrows area, is at Leach Canyon in Utah (Cook, 1965; Anderson and Rowley, 1975). Cook (1965) reported a thickness of at least $137 \mathrm{~m}$ at White River Narrows (figs. 6-8). Williams (1967) suggested the Caliente caldera complex as a source for the Leach Canyon, whereas Best, Christiansen, and others (1989) suggested an unnamed caldera northeast of the complex. The Leach Canyon Formation is widespread in the southeast part of the Narrows area, where it forms prominent cliffs, many of which are columnar jointed. Williams (1967) defined two members of the Leach Canyon, the Narrows Tuff Member and the overlying Table Butte Tuff Member. Only the Narrows Member is present in the White River Narrows area, and it is composed of upper, hornblende-bearing and lower, hornblende-free rhyolite (fig. 2) ash-flow tuff cooling units. Chemical compositions of the two ash-flow units, described following, are distinct.
The Condor Canyon Formation, which overlies the Leach Canyon Formation, was named by Cook (1965); it consists of the lower 9-m-thick Swett Tuff Member and the upper 32-m-thick Bauers Tuff Member (figs. 6-8). Both tuffs are composed of rhyolite ash-flow tuff (fig. 2) and were probably erupted from the Caliente caldera complex (Williams, 1967; Rowley and Siders, 1988). Armstrong (1970) reported K-Ar ages of 23.9 Ma and 22.1 Ma for the Swett and Bauers, respectively. Best, Christiansen, and others (1989) reported an ${ }^{40} \mathrm{Ar} /{ }^{39} \mathrm{Ar}$ age of $22.78 \mathrm{Ma}$ for the Bauers Tuff Member.

The basal part of the Swett Tuff Member is a palebrown and medium-gray vitrophyre as thick as $1.5 \mathrm{~m}$ overlain by a thin interval of densely welded pale-red tuff $(0.5 \mathrm{~m})$ that grades upward into an almost aphyric, poorly welded, pale-red tuff $(2 \mathrm{~m})$ that in turn is overlain by about $2 \mathrm{~m}$ of poorly welded pinkish-gray tuff (fig. 7). The Bauers Tuff Member includes a variably devitrified black vitrophyre several meters thick. Above its base is about $20 \mathrm{~m}$ of densely welded pale-red tuff (fig. 7). The uppermost part of the Bauers is characterized by densely welded tuff that weathers to form resistant slabs.

In the Narrows area (fig. 8), the Pahranagat Formation of Scott and others (in press) is exposed discontinuously above the Bauers Tuff Member (Condor Canyon Formation); the rhyolite tuff (fig. 2) is less than $15 \mathrm{~m}$ thick. 


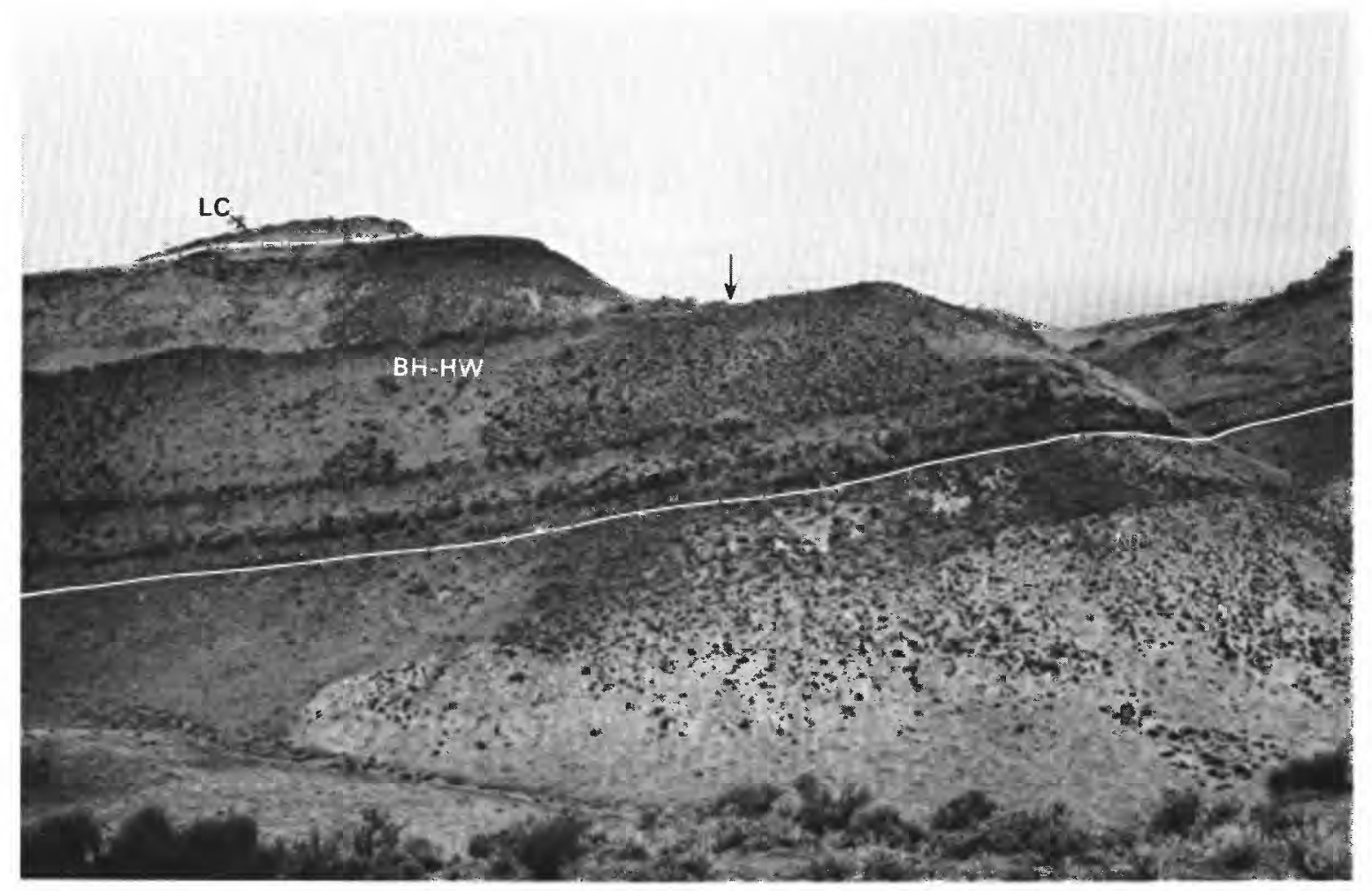

Figure 4. Outcrops of the continuous section from Baldhills up through the Hole-in-the-Wall Members (BH-HW) of the Isom Formation between the Lund Formation (NL) and the Leach Canyon Formation (LC). View to the west. This section, $1.5 \mathrm{~km}$ north of Fossil Peak, is the only complete section in this stratigraphic interval known in the White River Narrows area. Arrow indicates the position, on the leading edge of a backsloping dip slope, from which photograph shown in figure 5 was taken. The Baldhills Member of the Isom Formation and the lower and intermediate cooling units of the Shingle Pass Tuff are exposed between the top of the Lund and the base of the backsloping dip slope.

Williams (1967) reported that the thickness of the Pahranagat Formation, whose type section is in the Pahranagat Valley in southeastern Nevada, ranges from 0 to $35 \mathrm{~m}$ and averages $15 \mathrm{~m}$. As a consequence of weak welding and induration, the rhyolite tuff weathers to recessive outcrops. Ekren and others (1977) suggested the Kawich or Cactus Ranges as likely source areas for the tuff, whereas Best, Christiansen, and others (1989) suggested a source in the Central Nevada caldera complex that they refer to as the Kawich caldera. Deino and Best (1988) reported an ${ }^{40} \mathrm{Ar} /{ }^{39} \mathrm{Ar}$ age of 22.65 $\mathrm{Ma}$ for the tuff and suggested that it is correlative with all or part of the ash-flow tuffs known elsewhere as the tuff of White Blotch Spring (Ekren and others, 1971) and the granite-weathering tuff (Snyder and others, 1972).

The Harmony Hills Tuff, which overlies the Pahranagat Formation, is composed of dacite (fig. 2); its type locality is in the Harmony Mountains of Utah (Mackin, 1960). Cook (1965) recorded a thickness of $46 \mathrm{~m}$ in the White River Narrows (fig. 8). Blank (1959) suggested that the tuff was erupted from the Bull Valley center in southwestern Utah, whereas Best, Christiansen, and others (1989) suggested a source in the Caliente cauldron complex. Ages determined for the Harmony Hills Tuff are highly variable, but the ages of enclosing units constrain eruption of the tuff to between
22.5 and 22.0 Ma (Rowley and others, 1989); Best and others (1993) suggested an age of $22.2 \pm \mathrm{Ma}$. Outcrops of the Harmony Hills Tuff in the Narrows area are limited; thin and discontinuous exposures weather to form recessive outcrops.

The youngest ash-flow tuff exposed in the Narrows area is the Hiko Tuff. The Hiko type locality is on the east side of the Hiko Range in southern Nevada (Dolgoff, 1963). In the Narrows area, only the basal $15 \mathrm{~m}$ of the Hiko Tuff is exposed. The rhyolite tuff (fig. 2) weathers to prominent low cliffs covered by a distinctive moderate-reddish-brown patina. Ekren and others (1977) suggested that the Hiko Tuff was erupted from the Caliente caldera complex, and Rowley and Siders (1988) confirmed this interpretation. Taylor and others (1989) reported an ${ }^{40} \mathrm{Ar} /{ }^{39} \mathrm{Ar}$ age of $18.6 \mathrm{Ma}$ for the Hiko Tuff.

\section{SAMPLING AND ANALYTICAL METHODS}

Numerous samples of each ash-flow tuff unit were collected and analyzed in order to establish compositional ranges. This procedure is especially important for ash-flow tuffs, many of which are derived from zoned magma reservoirs (Hildreth, 1979, 1981). Establishing the full range of compositional zonation within each of the tuff units of the 


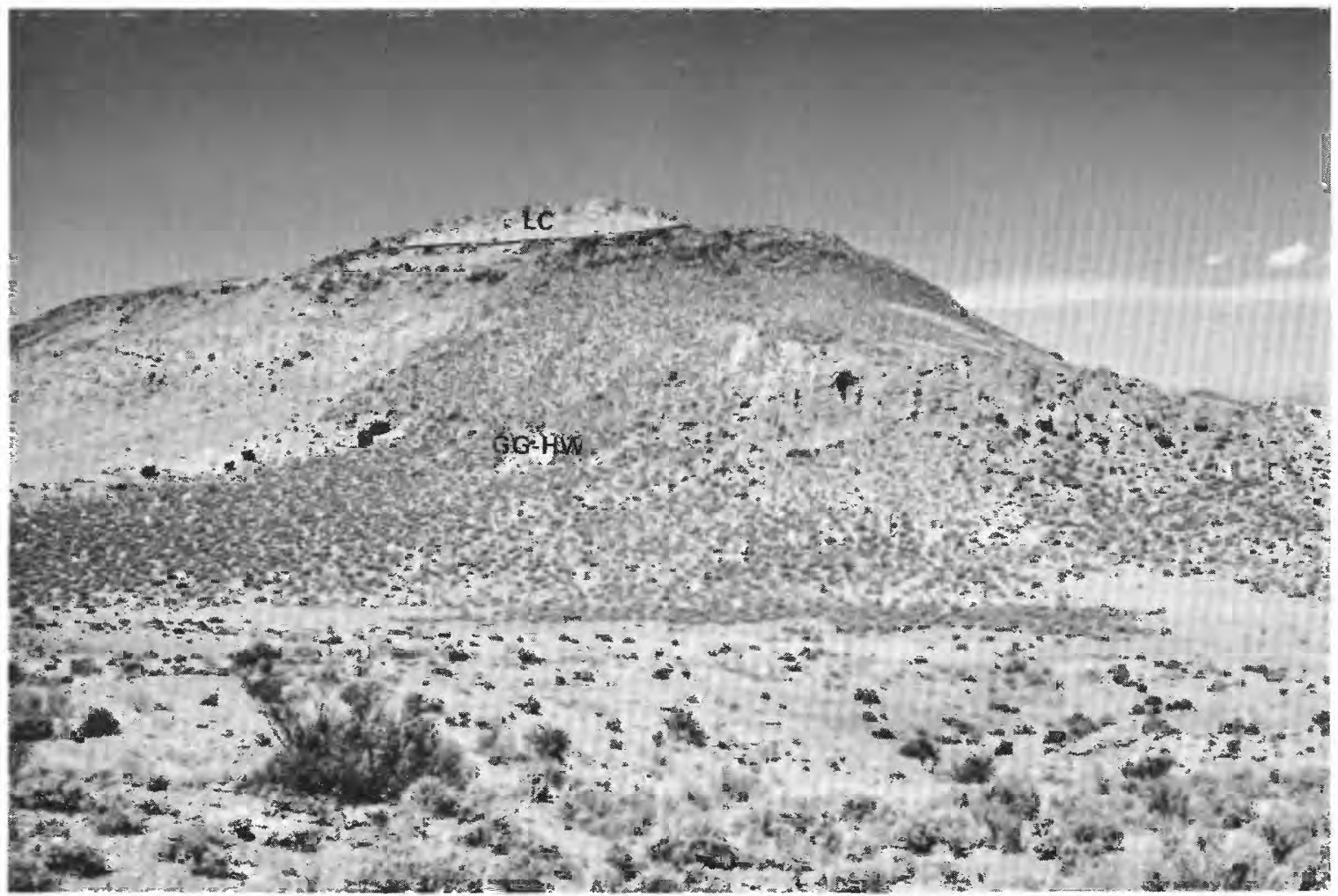

Figure 5. Upper part of the section between the Lund Formation and the Leach Canyon Formation (LC); this part of the section includes the tuff of the Golden Gate Range, the tuff of Hancock Summit, the upper cooling unit of the Shingle Pass Tuff, and the Hole-in-the-Wall Member of the Isom Formation (GG-HW). View to the west from point shown in figure 4.

southeastern Great Basin is essential if composition is to be employed as a tool for stratigraphic correlation. Compositional data for samples collected without regard to vertical position are unlikely to depict a full composition range because the stratigraphically lowest and highest parts of a unit may be overlooked in random sampling. Complete, unfaulted sections (table 1), hereafter referred to as compositional profiles, of 14 of the 18 ash-flow tuff stratigraphic units were identified; exposed sections of the other four units, the Baldhills and Hole-in-the-Wall Members of the Isom Formation, the tuff of Hancock Summit, and the Wah Wah Springs Formation, were too thin or incompletely exposed for meaningful vertical sampling.

Whole-rock samples were collected at 216 sites. Of these samples, only nine have anomalous (unrepresentative of the sampled ash-flow tuff unit) compositions. These nine samples are excluded from further consideration; their compositions may reflect alteration or weathering, incorporation of unrecognized xenolithic material, flow sorting during ashflow emplacement, or glass shard elutriation, or they may represent previously unrecognized local units. Samples were coarse crushed at the outcrop and all obvious xenolithic material removed. Of the 216 samples, 44 were collected in order to document vertical compositional zonation within the tuffs of the Narrows area. Two to five samples, depending on unit thickness, were collected at approximately evenly spaced sites between the base and top of each profile. Abundances for an extensive set (described following) of trace elements and for the major oxides were obtained for all of these samples. The remaining 163 samples, collected throughout the Seaman Range and without reference to height in section, provide representative areal coverage; compositional data for these samples allow comparison of large-geographic-area compositional variation with the small-area variation identified in the compositional profile of each of the Narrows area tuffs. Abundances of a restricted set (described following) of trace elements were determined for all 163 of these samples, and abundances for the extensive set of trace elements and for the major oxides were determined for a representative subset of these samples.

Recent compositional studies of ash-flow tuffs (Fridrich and Mahood, 1987; Boden, 1989) have relied on analysis of cognate pumice inclusions because these are considered to represent quenched magma. Because most of the middle Tertiary tuffs of the southeastern Great Basin are indurated and moderately to densely welded (pumices are flattened to the extent that they are inseparable from enclosing tuff matrix), it was not possible to collect pumice fragments for this compositional study. Lipman (1965) demonstrated that the compositions of middle Tertiary ash-flow tuff vitrophyre (including pumice) are, in some cases, considerably modified during postmagmatic processes, including devitrification; 


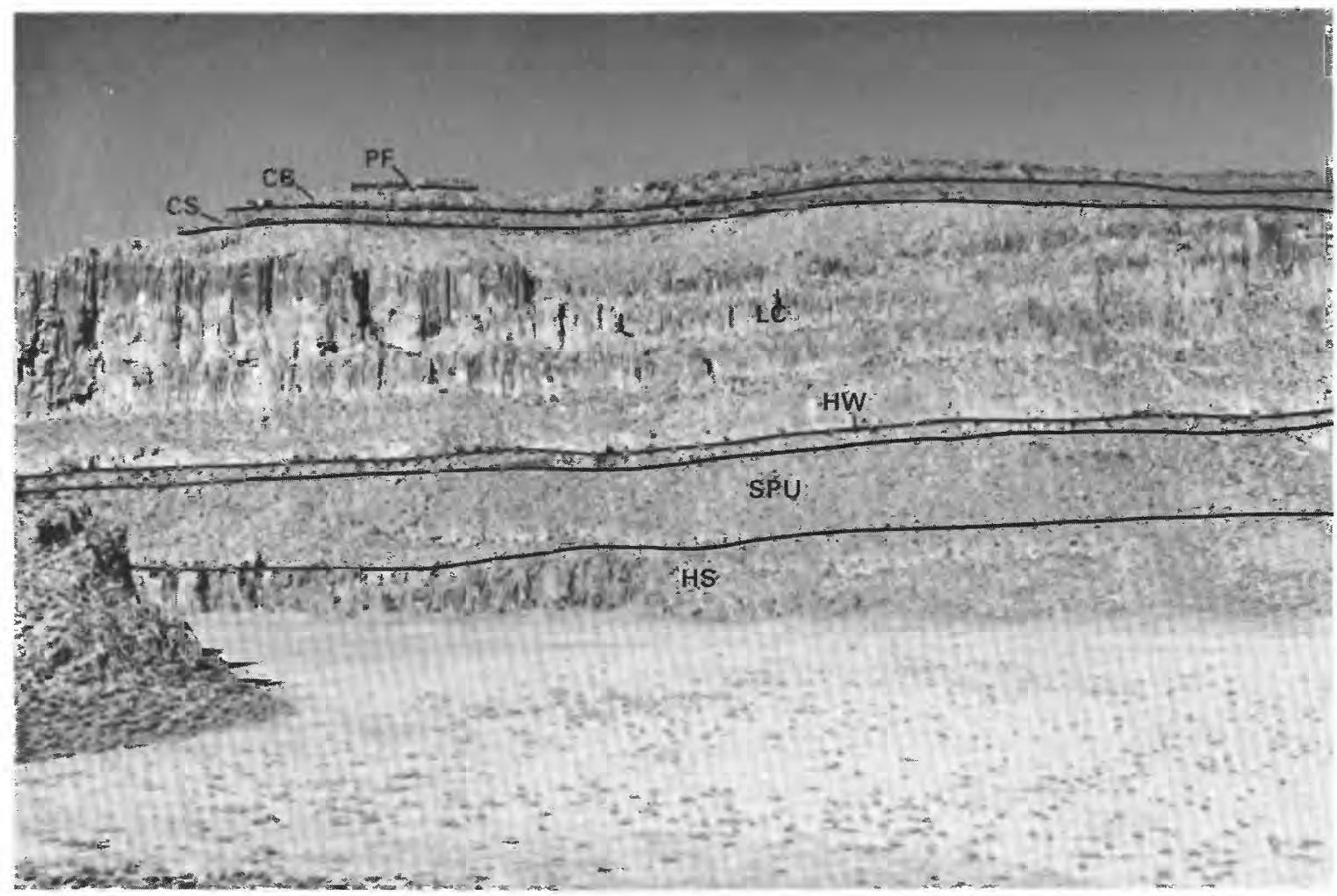

Figure 6. Tuff of Hancock Summit (HS), upper cooling unit of the Shingle Pass Tuff (SPU), Hole-in-the-Wall Member of the Isom Formation (HW), Leach Canyon Formation (LC), Swett Tuff Member of the Condor Canyon Formation (CS), Bauers Tuff Member of the Condor Canyon Formation (CB), and Pahranagat Formation (PF). View to the west. Section is on the west side of the northern White River Narrows. Note multiple flow units within the compound cooling unit of the Leach Canyon Formation; prominent slope-forming interval about one-fourth of the Leach Canyon Formation thickness up from its base marks the break between the lower and upper cooling units of the Narrows Member.

devitrified pumice blocks such as those contained in the tuffs of the Narrows area may be of questionable utility in compositional studies.

Potential modifications, resulting from glass shard elutriation and flow sorting during ash-flow emplacement, of whole-rock compositions determined for tuffs of the Narrows area from magma compositions have not been established; however, the coherence of the Narrows area compositional data and their moderately systematic variation among profile samples suggest that data presented here are generally representative of magma compositions and zonation within each source reservoir. In addition, the effects of sectoral compositional variation, as indicated by compositional overlap between samples from the profiles and those collected throughout the Seaman Range, suggest that sectoral compositional variation is minor. In order to verify that whole-rock ash-flow tuff samples are representative of magma compositions, a comparative study of pumice samples separated from one of the least welded and indurated tuffs of the Narrows area, such as the Pahranagat Formation, could be conducted. To further evaluate the potential effects of sectoral compositional variation, samples of the Narrows area tuffs from throughout their southeastern Great Basin distributions could be analyzed.

All chemical abundances were determined in analytical laboratories of the U.S. Geological Survey in Denver, Colorado. Major oxide abundances were determined by X-ray fluorescence techniques (Taggart and others, 1987) (analysts, J.E. Taggart, A.J. Bartel, D.F. Siems, E.C. Robb, and K. Stewart). $\mathrm{FeO}$ to $\mathrm{FeO}^{*}$ (total iron as $\mathrm{FeO}$ ) ratios were adjusted to 0.85 , and major oxide abundances were recalculated to 100 percent volatile free. Energy-dispersive X-ray fluorescence spectroscopy, using ${ }^{109} \mathrm{Cd}$ and ${ }^{241} \mathrm{Am}$ radioisotope excitation sources (Elsass and du Bray, 1982), was used to determine abundances of a restricted set $(\mathrm{Rb}, \mathrm{Sr}, \mathrm{Y}, \mathrm{Zr}$, $\mathrm{Nb}$, and $\mathrm{Ba}$ ) of trace elements (analyst, E.A. du Bray); the precision and accuracy of these data are discussed by Sawyer and Sargent (1989) and Yager and Quick (1992). The abundances of an extensive set of trace elements (Co, Ni, Cr, Cs, Hf, Sb, Ta, Th, U, Zn, Sc, La, Ce, Nd, Sm, Eu, Gd, Tb, Tm, $\mathrm{Yb}$, and $\mathrm{Lu}$ ) were determined by instrumental neutron activation analysis (Baedecker and McKown, 1987) (analysts, R.J. Knight, J.R. Budahn, and R.B. Vaughn). Analytical precision is graphically portrayed in figure 16 . 


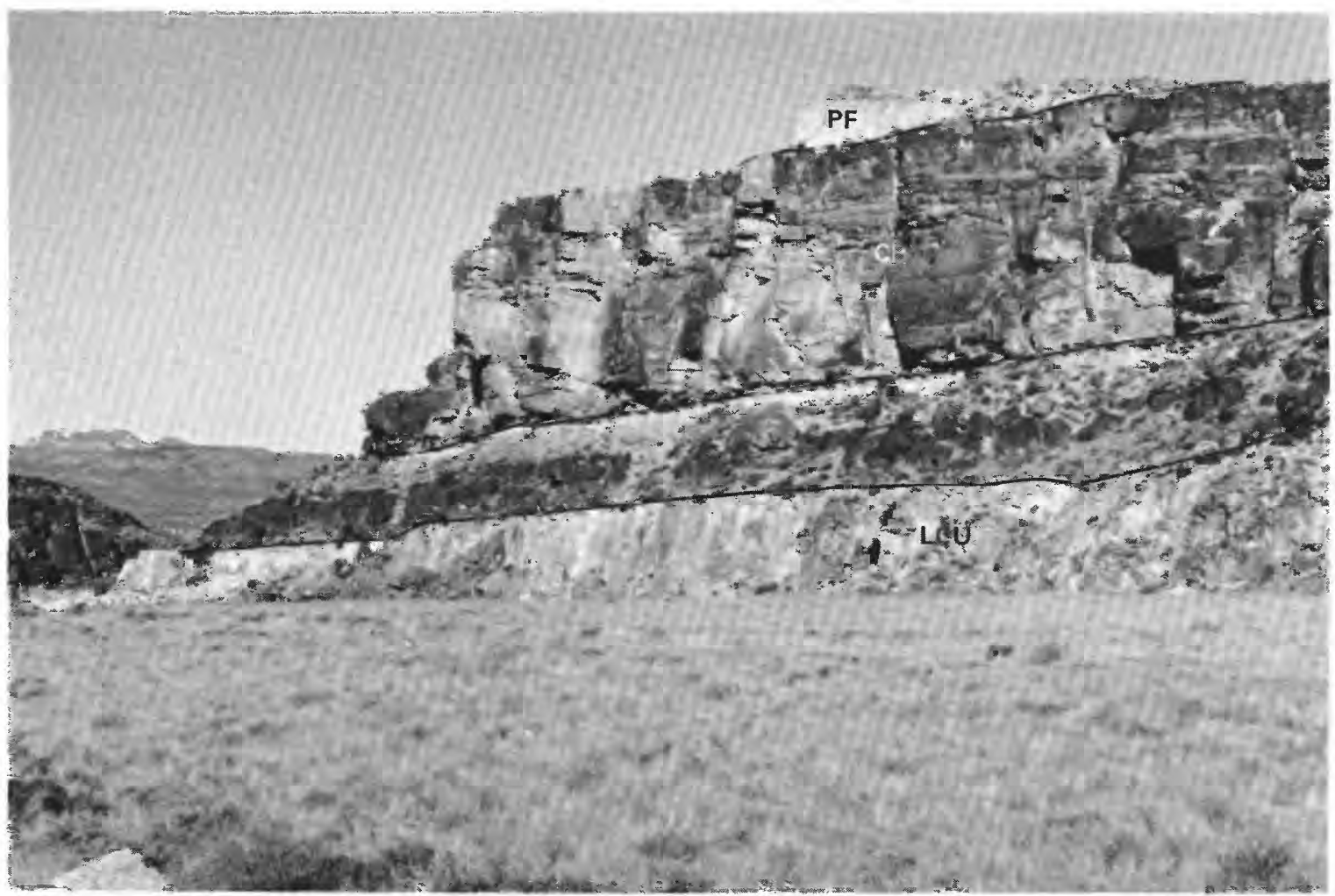

Figure 7. Uppermost part of the upper cooling unit of the Narrows Member (LCU) of the Leach Canyon Formation, the Swett Tuff Member of the Condor Canyon Formation (CS), the Bauers Tuff Member of the Condor Canyon Formation (CB), and the base of Pahranagat Formation (PF). View to the northeast. Section is on the east side of northern White River Narrows.

\section{GEOCHEMISTRY}

\section{COMPOSITIONAL CHARACTERISTICS}

The International Union of Geological Sciences classification of volcanic rocks (Le Bas and others, 1986) was applied to the compositions of the tuffs of the Narrows area (tables 3-5). On the basis of the total alkalis versus silica criterion of Irvine and Baragar (1971), all but one of the ashflow tuff units is subalkaline; all are members of the highpotassium calc-alkaline series defined by Ewart (1982). The Baldhills Member of the Isom Formation is transitionally alkaline and is trachydacite, whereas the other tuffs are rhyolite and dacite. Ash-flow tuffs exposed in the Narrows area are metaluminous to weakly peraluminous, and about half of them are corundum normative (table 5); these features may reflect minor, posteruptive alkali loss relative to alumina and are probably not primary magmatic characteristics.

As is typical for most calc-alkaline rocks, abundances of $\mathrm{Al}_{2} \mathrm{O}_{3}$, total iron, $\mathrm{MgO}, \mathrm{CaO}, \mathrm{P}_{2} \mathrm{O}_{5}, \mathrm{TiO}_{2}$, and $\mathrm{Sr}$ decrease continuously with increasing $\mathrm{SiO}_{2}$ in tuffs of the Narrows area, whereas abundances of $\mathrm{Na}_{2} \mathrm{O}, \mathrm{MnO}$, and $\mathrm{Zr}$ show no clear relationship with $\mathrm{SiO}_{2}$, and abundances of $\mathrm{K}_{2} \mathrm{O}$ and $\mathrm{Rb}$ increase with increasing $\mathrm{SiO}_{2}$ (fig. 9). Most of these variation patterns are linear or almost so. Compositional variation patterns portrayed by tuffs of the Narrows area are similar to those identified for calc-alkaline rocks of the East-Central
Nevada volcanic field (Gans and others, 1989; Feeley and Grunder, 1991) and Indian Peak caldera complex (Best, Christiansen, and Blank, 1989; Best and Christiansen, 1991).

Best, Christiansen, and others (1989) defined two compositional types of ash-flow tuff, the Monotony and Isom, in the Great Basin. In the Narrows area the Monotony type is represented by the Wah Wah Springs and Lund Formations and by the Monotony Tuff itself, whereas the Isom type is represented by the Petroglyph Cliff Ignimbrite and by the Baldhills and Hole-in-the-Wall Tuff Members of the Isom Formation. Monotony-type tuffs of the Narrows area are crystal-rich, voluminous, relatively featureless dacite, whereas Isom-type tuffs are crystal-poor plagioclasepyroxene phyric trachydacite tuff characterized by elevated abundances of $\mathrm{TiO}_{2}, \mathrm{~K}_{2} \mathrm{O}, \mathrm{Zr}$, and the middle to heavy rare earth elements relative to rocks of similar silica contents.

As suggested by Best, Christiansen, and others (1989), continued study of Great Basin tuffs could lead to the identification of additional compositional types. Classification of tuffs in the Narrows area using definitions of the Monotony and Isom types leaves fully two-thirds of these tuffs unclassified. These tuffs, most of those erupted from the Caliente and Central Nevada caldera complexes, would seem to belong to a third, and perhaps most common, compositional type. These tuffs are composed of rhyolite, are individually distinctive (based on phenocryst proportions, 
Table 3. Chemical composition of samples from composition profiles of middle Tertiary ash-flow tuffs in the Seaman Range, Nevada.

[Formations are arranged in stratigraphic order, from oldest to youngest. Within each formation, samples are also sequentially arranged from base to top. $\mathrm{FeO} / \mathrm{FeO} *$ (total iron as $\mathrm{FeO}$ ) is adjusted to 0.85 . Major oxide analyses are normalized to 100 percent, volatile free. Total ${ }_{\mathrm{i}}$, original analytical (pre-normalization) total, with total iron as $\mathrm{Fe}_{2} \mathrm{O}_{3}$. LOI, loss on ignition; bdl, below detection limit]

\begin{tabular}{|c|c|c|c|c|c|c|c|c|c|c|c|c|}
\hline \multirow[b]{2}{*}{ Sample No. } & \multicolumn{4}{|c|}{ Lund Formation } & \multicolumn{4}{|c|}{ Petroglyph Cliff Ignimbrite } & \multicolumn{4}{|c|}{ Monotony Tuff } \\
\hline & 201454 & 201455 & 201456 & 201457 & 201458 & 201459 & 201460 & 201719 & 201720 & 201721 & 201722 & 201723 \\
\hline \multicolumn{13}{|c|}{ Major oxide compositions (weight percent) } \\
\hline$\overline{\mathrm{SiO}_{2}}$ & 69.26 & 69.18 & 64.46 & 68.30 & 69.07 & 65.32 & 63.72 & 69.84 & 69.83 & 70.63 & 71.57 & 71.35 \\
\hline $\mathrm{Al}_{2} \mathrm{O}_{3}$ & 15.84 & 15.57 & 16.43 & 14.76 & 15.50 & 15.87 & 16.55 & 15.63 & 15.34 & 15.28 & 15.29 & 15.25 \\
\hline $\mathrm{Fe}_{2} \mathrm{O}_{3}$ & 0.49 & 0.57 & 0.83 & 0.67 & 0.62 & 0.77 & 0.81 & 0.49 & 0.49 & 0.45 & 0.36 & 0.40 \\
\hline $\mathrm{FeO}$ & 2.49 & 2.91 & 4.24 & 3.43 & 3.18 & 3.95 & 4.11 & 2.50 & 2.52 & 2.31 & 1.82 & 2.05 \\
\hline $\mathrm{MgO}$ & 0.86 & 0.97 & 2.00 & 1.09 & 0.86 & 1.47 & 1.94 & 1.49 & 1.35 & 1.18 & 0.90 & 1.15 \\
\hline $\mathrm{CaO}$ & 3.50 & 3.26 & 4.96 & 4.13 & 2.43 & 4.61 & 5.51 & 3.50 & 3.66 & 3.31 & 3.13 & 2.89 \\
\hline $\mathrm{Na}_{2} \mathrm{O}$ & 2.60 & 2.54 & 2.78 & 2.51 & 3.08 & 3.19 & 3.01 & 2.46 & 2.53 & 2.50 & 2.50 & 2.35 \\
\hline $\mathrm{K}_{2} \mathrm{O}$ & 4.24 & 4.30 & 3.31 & 4.26 & 4.21 & 3.58 & 3.06 & 3.61 & 3.78 & 3.88 & 4.06 & 4.14 \\
\hline $\mathrm{TiO}_{2}$ & 0.52 & 0.52 & 0.70 & 0.55 & 0.81 & 0.87 & 0.91 & 0.36 & 0.39 & 0.33 & 0.26 & 0.29 \\
\hline $\mathrm{P}_{2} \mathrm{O}_{5}$ & 0.17 & 0.15 & 0.21 & 0.23 & 0.20 & 0.27 & 0.30 & 0.10 & 0.08 & 0.07 & 0.08 & 0.07 \\
\hline $\mathrm{MnO}$ & 0.03 & 0.03 & 0.07 & 0.06 & 0.03 & 0.09 & 0.07 & 0.04 & 0.03 & 0.04 & 0.03 & 0.05 \\
\hline Total $_{i}$ & 99.93 & 99.19 & 99.48 & 99.51 & 99.50 & 99.92 & 99.66 & 99.60 & 99.52 & 99.41 & 99.50 & 99.65 \\
\hline LOI & 3.07 & 3.19 & 3.47 & 2.95 & 3.02 & 1.82 & 2.54 & 5.26 & 3.44 & 3.60 & 3.17 & 3.75 \\
\hline \multicolumn{13}{|c|}{ Trace element compositions (parts per million) } \\
\hline $\mathrm{Rb}$ & 176 & 167 & 143 & 132 & 126 & 112 & 77 & 130 & 122 & 124 & 128 & 134 \\
\hline $\mathrm{Sr}$ & 458 & 452 & 606 & 484 & 371 & 472 & 528 & 419 & 405 & 352 & 365 & 347 \\
\hline $\mathbf{Y}$ & 17 & 21 & 18 & 17 & 38 & 27 & 35 & 15 & 17 & 20 & 21 & 25 \\
\hline $\mathrm{Zr}$ & 213 & 211 & 221 & 196 & 327 & 287 & 292 & 131 & 139 & 136 & 126 & 140 \\
\hline $\mathrm{Nb}$ & 17 & 16 & 14 & 12 & 18 & 16 & 17 & 12 & 11 & 7 & 6 & 13 \\
\hline $\mathrm{Ba}$ & 914 & 934 & 777 & 912 & 1,007 & 930 & 888 & 1,182 & 1,207 & 1,309 & 1,325 & 1,276 \\
\hline Co & 4.81 & 5.77 & 10.5 & 10.6 & 3.38 & 7.53 & 6.76 & 4.72 & 4.57 & 4.70 & 3.03 & 3.72 \\
\hline $\mathrm{Ni}$ & 4.70 & 8.30 & bdl & 12.1 & 11.0 & 11.0 & 14.1 & 7.85 & bdl & bdl & 10.0 & bdl \\
\hline $\mathrm{Cr}$ & 3.54 & 2.74 & 16.0 & 10.7 & 3.29 & 6.87 & 5.31 & 4.85 & 5.03 & 3.67 & 4.89 & 5.57 \\
\hline Cs & 15.4 & 14.0 & 11.5 & 4.32 & 3.20 & 2.89 & 2.15 & 15.0 & 7.59 & 4.27 & 4.49 & 5.85 \\
\hline $\mathrm{Hf}$ & 5.83 & 5.71 & 6.28 & 5.79 & 8.06 & 6.95 & 7.06 & 3.92 & 4.19 & 3.96 & 3.73 & 3.89 \\
\hline $\mathrm{Sb}$ & 0.221 & 0.230 & 0.281 & 0.357 & 0.437 & 0.321 & 0.374 & 0.166 & 0.163 & 0.169 & 0.119 & 0.211 \\
\hline $\mathrm{Ta}$ & 1.46 & 1.44 & 1.27 & 1.20 & 1.46 & 1.24 & 1.25 & 0.878 & 0.837 & 0.868 & 0.846 & 1.16 \\
\hline Th & 20.8 & 20.5 & 18.6 & 19.5 & 17.1 & 14.8 & 14.7 & 12.3 & 12.3 & 13.4 & 15.0 & 14.3 \\
\hline $\mathbf{U}$ & 4.20 & 4.08 & 4.09 & 3.13 & 4.15 & 3.79 & 3.77 & 3.50 & 3.30 & 3.30 & 3.47 & 4.35 \\
\hline $\mathrm{Zn}$ & 54.4 & 61.1 & 69.6 & 57.3 & 50.7 & 81.6 & 66.6 & 48.7 & 50.7 & 50.7 & 41.2 & 52.9 \\
\hline Sc & 5.67 & 6.00 & 13.0 & 10.1 & 12.3 & 13.7 & 13.7 & 7.05 & 7.18 & 6.43 & 5.33 & 5.77 \\
\hline $\mathrm{La}$ & 61.4 & 56.2 & 55.4 & 52.7 & 58.3 & 49.2 & 50.6 & 40.7 & 44.9 & 46.6 & 52.1 & 48.1 \\
\hline $\mathrm{Ce}$ & 123 & 109 & 115 & 109 & 115 & 99.6 & 105 & 82.5 & 84.3 & 91.1 & 105 & 90.7 \\
\hline $\mathrm{Nd}$ & 43.8 & 42.6 & 47.5 & 41.0 & 51.4 & 42.5 & 45.3 & 32.6 & 33.8 & 35.0 & 40.5 & 36.1 \\
\hline $\mathrm{Sm}$ & 7.16 & 7.37 & 8.00 & 6.78 & 9.36 & 7.98 & 8.12 & 5.34 & 5.24 & 5.49 & 6.03 & 6.01 \\
\hline $\mathrm{Eu}$ & 1.32 & 1.36 & 1.58 & 1.31 & 1.76 & 1.55 & 1.61 & 1.17 & 1.20 & 1.24 & 1.24 & 1.17 \\
\hline Gd & 5.47 & 5.25 & 5.58 & 5.66 & 7.46 & 6.08 & 6.09 & 3.91 & 4.09 & 4.26 & 3.84 & 3.98 \\
\hline $\mathrm{Tb}$ & 0.655 & 0.641 & 0.737 & 0.659 & 1.040 & 0.884 & 0.894 & 0.474 & 0.455 & 0.454 & 0.474 & 0.552 \\
\hline $\mathrm{Tm}$ & 0.263 & 0.276 & 0.367 & 0.307 & 0.569 & 0.463 & 0.478 & 0.245 & 0.233 & 0.238 & 0.229 & 0.301 \\
\hline $\mathrm{Yb}$ & 1.56 & 1.59 & 2.08 & 1.86 & 3.59 & 2.89 & 2.94 & 1.52 & 1.42 & 1.41 & 1.39 & 1.86 \\
\hline $\mathrm{Lu}$ & 0.225 & 0.228 & 0.300 & 0.270 & 0.510 & 0.412 & 0.408 & 0.213 & 0.216 & 0.202 & 0.211 & 0.265 \\
\hline
\end{tabular}


Table 3. Chemical composition of samples from composition profiles of middle Tertiary ash-flow tuffs in the Seaman Range, Nevada-Continued.

\begin{tabular}{|c|c|c|c|c|c|c|c|c|c|c|c|}
\hline \multirow[b]{3}{*}{ Sample No. } & \multicolumn{4}{|c|}{ Shingle Pass Tuff } & \multirow{2}{*}{\multicolumn{2}{|c|}{$\begin{array}{l}\text { Tuff of the } \\
\text { Golden } \\
\text { Gate Range }\end{array}$}} & \multirow{2}{*}{\multicolumn{5}{|c|}{ Shingle Pass Tuff, upper cooling unit }} \\
\hline & \multicolumn{2}{|c|}{ Lower cooling unit } & \multicolumn{2}{|c|}{$\begin{array}{l}\text { Intermediate } \\
\text { cooling unit }\end{array}$} & & & & & & & \\
\hline & 201731 & 201730 & 201729 & 201728 & 201727 & 201447 & 201725 & 201724 & 201710 & 201711 & 201712 \\
\hline \multicolumn{12}{|c|}{ Major oxide compositions (weight percent) } \\
\hline$\overline{\mathrm{SiO}_{2}}$ & 75.04 & 74.67 & 74.66 & 73.27 & 77.63 & 76.27 & 75.24 & 73.98 & 73.28 & 74.50 & 74.14 \\
\hline $\mathrm{Al}_{2} \mathrm{O}_{3}$ & 13.25 & 13.61 & 13.48 & 13.58 & 12.15 & 12.83 & 13.27 & 13.24 & 14.55 & 13.63 & 13.89 \\
\hline $\mathrm{Fe}_{2} \mathrm{O}_{3}$ & 0.27 & 0.29 & 0.32 & 0.33 & 0.19 & 0.22 & 0.21 & 0.23 & 0.24 & 0.23 & 0.25 \\
\hline $\mathrm{FeO}$ & 1.39 & 1.47 & 1.62 & 1.71 & 0.98 & 1.12 & 1.08 & 1.18 & 1.24 & 1.19 & 1.27 \\
\hline $\mathrm{MgO}$ & 0.18 & 0.33 & 0.28 & 0.47 & 0.31 & 0.26 & 0.38 & 0.36 & 0.93 & 0.34 & 0.50 \\
\hline $\mathrm{CaO}$ & 1.00 & 0.99 & 1.01 & 1.86 & 0.95 & 1.19 & 1.10 & 2.31 & 1.92 & 1.34 & 1.49 \\
\hline $\mathrm{Na}_{2} \mathrm{O}$ & 3.09 & 2.89 & 2.99 & 3.00 & 2.63 & 2.60 & 2.92 & 3.03 & 2.42 & 3.09 & 2.74 \\
\hline $\mathrm{K}_{2} \mathrm{O}$ & 5.63 & 5.61 & 5.44 & 5.45 & 5.08 & 5.35 & 5.61 & 5.47 & 5.18 & 5.44 & 5.50 \\
\hline $\mathrm{TiO}_{2}$ & 0.14 & 0.14 & 0.18 & 0.21 & 0.08 & 0.15 & 0.15 & 0.16 & 0.18 & 0.18 & 0.18 \\
\hline $\mathrm{P}_{2} \mathrm{O}_{5}$ & bdl & bdl & bdl & 0.06 & bdl & bdl & bdl & bdl & bdl & bdl & bdl \\
\hline $\mathrm{MnO}$ & bdl & bdl & 0.02 & 0.04 & bdl & bdl & 0.03 & 0.04 & 0.06 & 0.05 & 0.04 \\
\hline Total $_{i}$ & 99.19 & 98.92 & 99.23 & 99.16 & 99.12 & 99.23 & 99.10 & 99.35 & 99.57 & 99.12 & 99.44 \\
\hline LOI & 0.96 & 1.80 & 1.14 & 1.80 & 1.11 & 0.91 & 1.03 & 1.76 & 5.97 & 2.89 & 3.54 \\
\hline \multicolumn{12}{|c|}{ Trace element compositions (parts per million) } \\
\hline$\overline{\mathrm{Rb}}$ & 215 & 223 & 202 & 194 & 196 & 157 & 202 & 202 & 183 & 192 & 175 \\
\hline $\mathrm{Sr}$ & 156 & 163 & 216 & 208 & 101 & 213 & 201 & 220 & 215 & 213 & 242 \\
\hline $\mathbf{Y}$ & 34 & 31 & 33 & 33 & 30 & 17 & 26 & 28 & 29 & 26 & 27 \\
\hline $\mathbf{Z r}$ & 197 & 211 & 216 & 223 & 91 & 143 & 152 & 162 & 156 & 154 & 162 \\
\hline $\mathrm{Nb}$ & 17 & 17 & 20 & 15 & 16 & 9 & 17 & 17 & 16 & 16 & 20 \\
\hline $\mathbf{B a}$ & 1,023 & 1,212 & 1,501 & 1,467 & 348 & 1,213 & 900 & 954 & 879 & 851 & 921 \\
\hline Co & 0.412 & 0.532 & 0.945 & 1.93 & 0.608 & 1.05 & 1.05 & 1.31 & 1.08 & 1.24 & 1.35 \\
\hline $\mathrm{Ni}$ & bdl & 10.4 & bdl & 8.72 & 5.60 & bdl & 5.60 & 5.49 & 7.30 & 5.50 & bdl \\
\hline $\mathrm{Cr}$ & 1.30 & 1.67 & bdl & 4.53 & 1.77 & 0.530 & 2.49 & 2.57 & 1.33 & 2.29 & 3.43 \\
\hline Cs & 7.55 & 6.38 & 5.36 & 5.84 & 4.38 & 3.35 & 6.16 & 5.79 & 6.49 & 6.05 & 6.10 \\
\hline $\mathrm{Hf}$ & 6.76 & 7.26 & 7.55 & 6.80 & 3.58 & 4.63 & 5.24 & 5.05 & 5.26 & 4.85 & 5.25 \\
\hline $\mathrm{Sb}$ & 1.08 & 1.00 & 1.07 & 0.629 & 0.444 & 0.312 & 0.604 & 0.431 & 0.984 & 0.729 & 0.875 \\
\hline Ta & 1.69 & 1.69 & 1.70 & 1.44 & 1.31 & 0.941 & 1.61 & 1.52 & 1.60 & 1.47 & 1.57 \\
\hline Th & 32.3 & 33.9 & 33.4 & 26.9 & 22.7 & 25.0 & 28.5 & 27.1 & 28.6 & 26.7 & 27.3 \\
\hline $\mathrm{U}$ & 7.08 & 6.22 & 6.63 & 4.92 & 4.43 & 2.90 & 5.92 & 4.67 & 6.28 & 6.90 & 7.07 \\
\hline $\mathrm{Zn}$ & 47.4 & 52.8 & 45.5 & 38.7 & 29.5 & 29.9 & 36.1 & 34.1 & 38.5 & 40.1 & 39.3 \\
\hline Sc & 5.57 & 5.89 & 6.18 & 5.51 & 2.17 & 2.34 & 3.07 & 3.20 & 3.09 & 3.14 & 3.48 \\
\hline La & 69.9 & 75.4 & 82.8 & 63.5 & 28.1 & 62.4 & 66.8 & 62.2 & 66.3 & 62.8 & 61.7 \\
\hline $\mathrm{Ce}$ & 127 & 153 & 145 & 124 & 53.7 & 114 & 124 & 119 & 130 & 119 & 118 \\
\hline Nd & 50.2 & 55.6 & 58.1 & 47.0 & 27.0 & 45.8 & 45.1 & 42.5 & 42.8 & 41.4 & 41.1 \\
\hline $\mathrm{Sm}$ & 8.15 & 8.84 & 9.33 & 7.36 & 5.68 & 6.74 & 6.76 & 6.29 & 6.95 & 6.41 & 6.35 \\
\hline $\mathrm{Eu}$ & 1.18 & 1.39 & 1.28 & 1.44 & 0.616 & 1.17 & 0.884 & 0.878 & 0.865 & 0.830 & 0.878 \\
\hline Gd & 6.09 & bdl & 7.07 & 5.84 & 4.64 & 4.24 & 5.82 & 5.45 & 5.76 & 4.83 & 5.19 \\
\hline $\mathrm{Tb}$ & 0.842 & 0.860 & 0.923 & 0.796 & 0.658 & 0.574 & 0.636 & 0.615 & 0.646 & 0.617 & 0.644 \\
\hline $\mathrm{Tm}$ & 0.494 & bdl & 0.506 & 0.454 & bdl & 0.323 & bdl & bdl & 0.415 & 0.374 & 0.386 \\
\hline $\mathrm{Yb}$ & 2.93 & 3.04 & 3.11 & 2.76 & 2.32 & 1.92 & 2.41 & 2.40 & 2.62 & 2.36 & 2.43 \\
\hline Lu & 0.425 & 0.434 & 0.450 & 0.395 & 0.323 & 0.283 & 0.345 & 0.350 & 0.381 & 0.348 & 0.353 \\
\hline
\end{tabular}


Table 3. Chemical composition of samples from composition profiles of middle Tertiary ash-flow tuffs in the Seaman Range, Nevada-Continued.

\begin{tabular}{|c|c|c|c|c|c|c|c|c|c|}
\hline \multirow[b]{3}{*}{ Sample No. } & \multicolumn{5}{|c|}{ Leach Canyon Formation, Narrows Member } & \multirow{2}{*}{\multicolumn{4}{|c|}{$\begin{array}{c}\text { Condor Canyon Formation } \\
\text { Swett Tuff Member }\end{array}$}} \\
\hline & \multicolumn{2}{|c|}{ Lower cooling unit } & \multicolumn{3}{|c|}{ Upper cooling unit } & & & & \\
\hline & 201714 & 201715 & 201716 & 201717 & 201718 & 201697 & 201698 & 201699 & 201700 \\
\hline \multicolumn{10}{|c|}{ Major oxide compositions (weight percent) } \\
\hline $\mathrm{SiO}_{2}$ & 74.74 & 75.95 & 73.63 & 72.46 & 70.62 & 73.61 & 72.82 & 69.90 & 67.89 \\
\hline $\mathrm{Al}_{2} \mathrm{O}_{3}$ & 13.46 & 12.96 & 13.46 & 13.40 & 13.29 & 14.30 & 14.42 & 16.16 & 17.88 \\
\hline $\mathrm{Fe}_{2} \mathrm{O}_{3}$ & 0.16 & 0.19 & 0.28 & 0.27 & 0.26 & 0.22 & 0.25 & 0.28 & 0.31 \\
\hline $\mathrm{FeO}$ & 0.83 & 0.95 & 1.44 & 1.39 & 1.33 & 1.12 & 1.29 & 1.42 & 1.59 \\
\hline MgO & 0.92 & 0.31 & 0.64 & 0.54 & 0.47 & 0.52 & 0.42 & 1.71 & 2.60 \\
\hline $\mathrm{CaO}$ & 1.83 & 1.09 & 1.97 & 2.63 & 5.34 & 0.99 & 1.28 & 2.84 & 3.65 \\
\hline $\mathrm{Na}_{2} \mathrm{O}$ & 2.63 & 3.34 & 3.39 & 4.18 & 3.14 & 3.03 & 3.32 & 2.46 & 1.84 \\
\hline $\mathrm{K}_{2} \mathrm{O}$ & 5.23 & 4.97 & 4.78 & 4.71 & 5.15 & 5.87 & 5.74 & 4.76 & 3.69 \\
\hline $\mathrm{TiO}_{2}$ & 0.16 & 0.18 & 0.28 & 0.27 & 0.26 & 0.30 & 0.36 & 0.38 & 0.40 \\
\hline $\mathrm{P}_{2} \mathrm{O}_{5}$ & bdl & bdl & 0.08 & 0.09 & 0.10 & bdl & 0.06 & 0.06 & 0.07 \\
\hline $\mathrm{MnO}$ & 0.04 & 0.04 & 0.04 & 0.04 & 0.05 & 0.04 & 0.04 & 0.04 & 0.07 \\
\hline Total $_{i}$ & 99.67 & 99.41 & 99.26 & 99.17 & 99.28 & 99.51 & 99.05 & 99.05 & 99.74 \\
\hline LOI & 5.25 & 0.56 & 1.05 & 3.52 & 3.55 & 4.30 & 3.19 & 9.78 & 14.6 \\
\hline \multicolumn{10}{|c|}{ Trace element compositions (parts per million) } \\
\hline $\mathbf{R b}$ & 214 & 185 & 158 & 152 & 144 & 153 & 156 & 125 & 107 \\
\hline $\mathrm{Sr}$ & 105 & 126 & 249 & 294 & 264 & 159 & 235 & 297 & 303 \\
\hline Y & 17 & 20 & 18 & 20 & 19 & 27 & 26 & 29 & 27 \\
\hline $\mathbf{Z r}$ & 95 & 107 & 133 & 149 & 155 & 259 & 287 & 291 & 306 \\
\hline $\mathrm{Nb}$ & 16 & 15 & 14 & 11 & 14 & 16 & 16 & 16 & 20 \\
\hline $\mathrm{Ba}$ & 258 & 396 & 893 & 1,001 & 872 & 1,152 & 1,197 & 937 & 753 \\
\hline Co & 1.160 & 1.73 & 3.00 & 2.82 & 3.34 & 0.787 & 1.25 & 1.43 & 1.19 \\
\hline $\mathrm{Ni}$ & 2.40 & bdl & 9.83 & 5.50 & bdl & 7.38 & 11.0 & bdl & bdl \\
\hline $\mathrm{Cr}$ & bdl & 1.73 & 4.50 & 4.20 & 3.63 & 1.91 & bdl & 2.69 & 1.25 \\
\hline Cs & 12.5 & 6.64 & 5.24 & 2.72 & 3.06 & 5.27 & 5.51 & 4.68 & 11.6 \\
\hline $\mathrm{Hf}$ & 3.58 & 3.69 & 4.43 & 4.38 & 4.45 & 7.49 & 7.77 & 8.26 & 8.97 \\
\hline $\mathrm{Sb}$ & 1.44 & 0.714 & 0.539 & 0.386 & 0.525 & 0.524 & 0.468 & 0.552 & 0.985 \\
\hline $\mathrm{Ta}$ & 1.71 & 1.65 & 1.46 & 1.44 & 1.41 & 1.37 & 1.29 & 1.41 & 1.74 \\
\hline Th & 37.4 & 34.8 & 28.9 & 26.9 & 27.8 & 22.6 & 21.4 & 23.7 & 45.6 \\
\hline $\mathbf{U}$ & 9.55 & 6.55 & 5.33 & 4.47 & 4.94 & 5.61 & 5.04 & 4.41 & 5.55 \\
\hline $\mathrm{Zn}$ & 24.0 & 25.4 & 34.2 & 32.4 & 31.3 & 39.6 & 43.9 & 46.7 & 48.8 \\
\hline Sc & 1.98 & 2.22 & 3.06 & 2.93 & 2.91 & 3.88 & 4.06 & 4.62 & 4.36 \\
\hline $\mathbf{L a}$ & 35.8 & 42.2 & 50.5 & 49.2 & 46.1 & 65.3 & 60.4 & 51.9 & 70.7 \\
\hline $\mathrm{Ce}$ & 64.5 & 72.8 & 88.5 & 97.4 & 81.5 & 126 & 121 & 135 & 149 \\
\hline Nd & 18.4 & 22.5 & 28.6 & 31.6 & 27.1 & 52.5 & 46.3 & 41.9 & 51.6 \\
\hline $\mathrm{Sm}$ & 2.66 & 3.27 & 4.32 & 4.57 & 4.20 & 8.40 & 7.42 & 7.42 & 8.34 \\
\hline $\mathrm{Eu}$ & 0.361 & 0.486 & 0.735 & 0.802 & 0.698 & 1.21 & 1.30 & 1.17 & 0.954 \\
\hline Gd & bdl & bdl & 3.72 & 3.44 & 3.50 & 6.00 & 5.95 & 5.72 & 5.97 \\
\hline $\mathrm{Tb}$ & 0.256 & 0.311 & 0.396 & 0.420 & 0.390 & 0.836 & 0.757 & 0.752 & 0.718 \\
\hline $\mathrm{Tm}$ & bdl & bdl & 0.247 & 0.257 & 0.254 & 0.418 & 0.406 & 0.410 & 0.445 \\
\hline $\mathrm{Yb}$ & 1.54 & 1.48 & 1.62 & 1.58 & 1.61 & 2.66 & 2.52 & 2.62 & 2.65 \\
\hline Lu & 0.238 & 0.237 & 0.239 & 0.222 & 0.245 & 0.376 & 0.367 & 0.382 & 0.382 \\
\hline
\end{tabular}


Table 3. Chemical composition of samples from composition profiles of middle Tertiary ash-flow tuffs in the Seaman Range, Nevada-Continued.

\begin{tabular}{|c|c|c|c|c|c|c|c|c|c|c|c|c|}
\hline \multirow[b]{2}{*}{ Sample No. } & \multicolumn{5}{|c|}{$\begin{array}{c}\text { Condor Canyon Formation } \\
\text { Bauers Tuff Member }\end{array}$} & \multicolumn{3}{|c|}{ Pahranagat Formation } & \multicolumn{2}{|c|}{$\begin{array}{l}\text { Harmony } \\
\text { Hills Tuff }\end{array}$} & \multicolumn{2}{|c|}{ Hiko Tuff } \\
\hline & 201701 & 201702 & 201703 & 201704 & 201709 & 201878 & 201879 & 201880 & 201706 & 201705 & 201509 & 201511 \\
\hline \multicolumn{13}{|c|}{ Major oxide compositions (weight percent) } \\
\hline$\overline{\mathrm{SiO}_{2}}$ & 72.60 & 71.59 & 71.81 & 71.99 & 71.38 & 75.02 & 73.39 & 78.16 & 63.22 & 64.22 & 69.41 & 69.23 \\
\hline $\mathrm{Al}_{2} \mathrm{O}_{3}$ & 14.44 & 15.18 & 14.75 & 14.70 & 14.26 & 13.69 & 12.71 & 11.76 & 15.06 & 14.77 & 15.57 & 14.73 \\
\hline $\mathrm{Fe}_{2} \mathrm{O}_{3}$ & 0.25 & 0.25 & 0.27 & 0.25 & 0.26 & 0.19 & 0.20 & 0.17 & 0.98 & 0.82 & 0.40 & 0.36 \\
\hline $\mathrm{FeO}$ & 1.26 & 1.29 & 1.37 & 1.27 & 1.30 & 0.95 & 1.04 & 0.89 & 4.98 & 4.21 & 2.04 & 1.86 \\
\hline $\mathrm{MgO}$ & 0.46 & 0.50 & 0.38 & 0.38 & 0.36 & 1.08 & 0.34 & 0.25 & 3.18 & 2.61 & 1.14 & 1.01 \\
\hline $\mathrm{CaO}$ & 1.16 & 1.39 & 1.44 & 1.45 & 2.69 & 1.22 & 3.74 & 1.07 & 4.64 & 5.31 & 2.60 & 4.30 \\
\hline $\mathrm{Na}_{2} \mathrm{O}$ & 3.41 & 3.59 & 3.66 & 3.75 & 3.65 & 2.62 & 3.06 & 2.98 & 2.90 & 3.02 & 3.20 & 3.42 \\
\hline $\mathrm{K}_{2} \mathrm{O}$ & 6.01 & 5.83 & 5.95 & 5.77 & 5.70 & 4.93 & 5.13 & 4.50 & 3.85 & 3.96 & 4.99 & 4.52 \\
\hline $\mathrm{TiO}_{2}$ & 0.31 & 0.32 & 0.33 & 0.31 & 0.30 & 0.17 & 0.18 & 0.15 & 0.81 & 0.70 & 0.43 & 0.39 \\
\hline $\mathrm{P}_{2} \mathrm{O}_{5}$ & 0.06 & bdl & bdl & 0.08 & 0.07 & 0.05 & 0.13 & bdl & 0.30 & 0.32 & 0.15 & 0.13 \\
\hline $\mathrm{MnO}$ & 0.04 & 0.05 & 0.05 & 0.04 & 0.04 & 0.08 & 0.06 & 0.05 & 0.09 & 0.07 & 0.05 & 0.04 \\
\hline Total $_{\mathbf{i}}$ & 99.43 & 98.94 & 98.98 & 99.22 & 99.10 & 99.87 & 99.13 & 99.48 & 99.65 & 99.60 & 99.38 & 99.35 \\
\hline$\underline{\mathrm{LOI}}$ & 3.01 & 1.30 & 0.51 & 0.46 & 1.45 & 4.06 & 2.28 & 0.74 & 2.15 & 1.66 & 2.20 & 0.92 \\
\hline \multicolumn{13}{|c|}{ Trace element compositions (parts per million) } \\
\hline$\overline{\mathbf{R b}}$ & 189 & 152 & 188 & 191 & 187 & 186 & 140 & 139 & 126 & 114 & 146 & 93 \\
\hline $\mathrm{Sr}$ & 240 & 314 & 284 & 289 & 313 & 152 & 199 & 154 & 619 & 727 & 506 & 453 \\
\hline $\mathbf{Y}$ & 25 & 22 & 27 & 23 & 22 & 23 & 20 & 17 & 25 & 21 & 12 & 17 \\
\hline $\mathrm{Zr}$ & 276 & 278 & 290 & 283 & 272 & 112 & 112 & 110 & 201 & 190 & 202 & 183 \\
\hline $\mathrm{Nb}$ & 13 & 13 & 14 & 13 & 17 & 14 & 10 & 11 & 12 & 10 & 11 & 15 \\
\hline $\mathbf{B a}$ & 1,083 & 1,444 & 1,255 & 1,354 & 1,370 & 338 & 506 & 450 & 820 & 904 & 1,032 & 956 \\
\hline Co & 1.16 & 1.26 & 1.27 & 1.24 & 1.52 & 0.735 & 1.83 & 1.02 & 15.7 & 14.7 & 4.78 & 4.81 \\
\hline $\mathrm{Ni}$ & 9.36 & 6.28 & 8.57 & 6.82 & 6.20 & bdl & bdl & bdl & 26.9 & 23.4 & bdl & bdl \\
\hline $\mathrm{Cr}$ & 2.08 & bdl & 0.390 & 1.82 & 1.80 & 0.809 & 0.669 & 0.991 & 43.1 & 42.2 & 2.95 & 6.40 \\
\hline Cs & 9.04 & 4.21 & 5.71 & 4.88 & 5.42 & 10.8 & 1.95 & 2.02 & 5.34 & 5.56 & 4.89 & 1.76 \\
\hline Hf & 8.17 & 8.45 & 8.32 & 8.38 & 7.94 & 3.87 & 3.60 & 3.49 & 5.71 & 5.87 & 5.55 & 4.77 \\
\hline $\mathrm{Sb}$ & 1.03 & 0.684 & 0.783 & 0.731 & 0.591 & 0.519 & 0.216 & 0.249 & 0.502 & 0.473 & 0.372 & 0.304 \\
\hline Ta & 1.36 & 1.38 & 1.33 & 1.31 & 1.30 & 1.41 & 1.09 & 1.07 & 0.863 & 0.843 & 1.41 & 1.39 \\
\hline Th & 35.1 & 35.4 & 34.2 & 33.8 & 33.1 & 21.3 & 16.6 & 16.3 & 19.8 & 19.7 & 19.3 & 21.3 \\
\hline U & 9.31 & 7.41 & 7.27 & 8.20 & 7.53 & 4.69 & 3.31 & 3.56 & 4.37 & 4.67 & 5.07 & 6.86 \\
\hline $\mathrm{Zn}$ & 40.2 & 40.6 & 37.8 & 32.5 & 38.5 & 39.8 & 36.0 & 28.2 & 72.6 & 56.3 & 47.1 & 38.0 \\
\hline Sc & 3.76 & 3.99 & 3.73 & 3.77 & 3.70 & 2.51 & 2.39 & 2.28 & 12.9 & 12.3 & 4.01 & 3.80 \\
\hline $\mathrm{La}$ & 66.5 & 66.7 & 64.6 & 63.9 & 62.7 & 40.8 & 36.2 & 36.1 & 50.3 & 50.4 & 50.9 & 49.9 \\
\hline $\mathrm{Ce}$ & 129 & 135 & 129 & 127 & 125 & 79.3 & 71.2 & 68.4 & 104 & 102 & 99.2 & 98.8 \\
\hline Nd & 48.8 & 49.6 & 46.4 & 46.6 & 46.0 & 26.9 & 25.5 & 24.7 & 42.1 & 44.1 & 34.5 & 34.0 \\
\hline Sm & 7.26 & 7.18 & 7.03 & 7.15 & 7.29 & 4.72 & 3.99 & 4.02 & 7.62 & 7.45 & 5.82 & 5.58 \\
\hline $\mathrm{Eu}$ & 1.09 & 1.26 & 1.16 & 1.22 & 1.16 & 0.556 & 0.631 & 0.567 & 1.57 & 1.54 & 1.20 & 1.12 \\
\hline Gd & 5.08 & 5.40 & 5.16 & 5.56 & 5.62 & 3.53 & 3.13 & 3.09 & 5.67 & 5.49 & 4.44 & 3.97 \\
\hline $\mathrm{Tb}$ & 0.659 & 0.664 & 0.634 & 0.623 & 0.636 & 0.512 & 0.409 & 0.412 & 0.737 & 0.677 & 0.531 & 0.489 \\
\hline $\mathrm{Tm}$ & 0.387 & 0.372 & 0.366 & 0.360 & 0.372 & 0.307 & 0.233 & 0.232 & 0.342 & 0.338 & 0.264 & bdl \\
\hline $\mathrm{Yb}$ & 2.39 & 2.33 & 2.28 & 2.30 & 2.32 & 1.95 & 1.45 & 1.48 & 2.07 & 2.05 & 1.57 & 1.57 \\
\hline $\mathrm{Lu}$ & 0.353 & 0.349 & 0.321 & 0.342 & 0.326 & 0.286 & 0.213 & 0.216 & 0.296 & 0.293 & 0.226 & 0.231 \\
\hline
\end{tabular}


Table 4. Chemical compositions of middle Tertiary ash-flow tuffs in the White River Narrows area, Nevada.

[Within unit, relative stratigraphic positions are not known. $\mathrm{FeO} / \mathrm{FeO}$ (total iron as $\mathrm{FeO}$ ) is adjusted to 0.85 . Major oxide analyses are normalized to 100 percent, volatile free. Total, original analytical (pre-normalization) total with total iron as $\mathrm{Fe}_{2} \mathrm{O}_{3}$. LOI, loss on ignition; bdl, below detection limit; leaders (--), not analyzed for]

\begin{tabular}{|c|c|c|c|c|c|c|c|c|c|c|c|c|}
\hline \multirow[b]{2}{*}{ Sample No. } & \multirow{2}{*}{$\begin{array}{l}\text { Wah Wah } \\
\text { Springs } \\
\text { Formation } \\
201405\end{array}$} & \multicolumn{3}{|c|}{ Lund Formation } & \multirow{2}{*}{$\begin{array}{c}\text { Petroglyph } \\
\text { Cliff } \\
\text { Ignimbrite } \\
201398 \\
\end{array}$} & \multicolumn{2}{|c|}{ Monotony Tuff } & \multicolumn{5}{|c|}{$\begin{array}{l}\text { Isom Formation } \\
\text { Baldhills Tuff Member }\end{array}$} \\
\hline & & 201383 & 201392 & 201430 & & 201376 & 201461 & 201363 & 201381 & 201466 & 201467 & 201468 \\
\hline \multicolumn{13}{|c|}{ Major oxide compositions (weight percent) } \\
\hline$\overline{\mathrm{SiO}_{2}}$ & 64.39 & 65.47 & 69.34 & 70.51 & 68.18 & 71.16 & 69.49 & 68.12 & 67.97 & 66.21 & 66.90 & 66.92 \\
\hline $\mathrm{Al}_{2} \mathrm{O}_{3}$ & 15.64 & 16.21 & 15.48 & 15.21 & 15.39 & 15.14 & 15.67 & 15.45 & 15.63 & 16.19 & 15.40 & 15.59 \\
\hline $\mathrm{Fe}_{2} \mathrm{O}_{3}$ & 0.86 & 0.77 & 0.57 & 0.50 & 0.65 & 0.40 & 0.50 & 0.58 & 0.54 & 0.65 & 0.73 & 0.62 \\
\hline $\mathrm{FeO}$ & 4.37 & 3.90 & 2.92 & 2.55 & 3.34 & 2.03 & 2.52 & 2.95 & 2.74 & 3.32 & 3.74 & 3.18 \\
\hline $\mathrm{MgO}$ & 2.43 & 2.02 & 1.07 & 0.76 & 0.94 & 1.07 & 1.64 & 0.49 & 0.74 & 1.17 & 0.79 & 0.83 \\
\hline $\mathrm{CaO}$ & 4.92 & 4.60 & 3.23 & 2.83 & 2.92 & 3.09 & 3.83 & 1.86 & 1.96 & 2.73 & 2.19 & 2.79 \\
\hline $\mathrm{Na}_{2} \mathrm{O}$ & 2.99 & 2.88 & 2.48 & 2.81 & 3.48 & 2.57 & 2.30 & 3.46 & 3.49 & 3.46 & 3.47 & 3.28 \\
\hline $\mathrm{K}_{2} \mathrm{O}$ & 3.50 & 3.25 & 4.17 & 4.16 & 4.02 & 4.15 & 3.59 & 6.02 & 5.88 & 5.05 & 5.59 & 5.58 \\
\hline $\mathrm{TiO}_{2}$ & 0.65 & 0.63 & 0.53 & 0.50 & 0.80 & 0.28 & 0.35 & 0.84 & 0.80 & 0.91 & 0.86 & 0.90 \\
\hline $\mathrm{P}_{2} \mathrm{O}_{5}$ & 0.18 & 0.20 & 0.15 & 0.15 & 0.21 & 0.07 & 0.07 & 0.17 & 0.17 & 0.24 & 0.23 & 0.25 \\
\hline $\mathrm{MnO}$ & 0.07 & 0.06 & 0.05 & 0.01 & 0.07 & 0.03 & 0.04 & 0.05 & 0.08 & 0.08 & 0.10 & 0.06 \\
\hline Total $_{i}$ & 99.79 & 99.83 & 99.34 & 99.57 & 99.71 & 100.13 & 99.84 & 99.14 & 99.30 & 99.01 & 100.02 & 99.28 \\
\hline LOI & 1.47 & 3.19 & 3.42 & 2.01 & 2.54 & 3.51 & 5.74 & 1.05 & 1.75 & 2.89 & 1.55 & 2.10 \\
\hline \multicolumn{13}{|c|}{ Trace element compositions (parts per million) } \\
\hline$\overline{\mathrm{Rb}}$ & 126 & 125 & 167 & 135 & 131 & 142 & 109 & 210 & 191 & 193 & 204 & 210 \\
\hline $\mathrm{Sr}$ & 530 & 601 & 436 & 412 & 400 & 354 & 364 & 441 & 477 & 434 & 396 & 490 \\
\hline $\mathbf{Y}$ & 24 & 26 & 21 & 19 & 33 & 13 & 15 & 33 & 41 & 41 & 38 & 38 \\
\hline $\mathrm{Zr}$ & 157 & 204 & 218 & 208 & 311 & 146 & 157 & 471 & 492 & 510 & 492 & 515 \\
\hline $\mathrm{Nb}$ & 13 & 16 & 20 & 18 & 19 & 11 & 8 & 25 & 23 & 21 & 21 & 23 \\
\hline $\mathrm{Ba}$ & 823 & 839 & 966 & 1,017 & 1,063 & 1,360 & 1,144 & 1,433 & 1,553 & 1,306 & 1,319 & 1,348 \\
\hline Co & 14.3 & - & 5.86 & - & - & - & 4.97 & - & - & - & 3.95 & -- \\
\hline $\mathrm{Ni}$ & 22 & -- & 14.1 & -- & .- & -- & 20 & - & -- & -- & 12 & - \\
\hline $\mathrm{Cr}$ & 40.9 & -- & 14.2 & -- & -. & - & 5.20 & -- & -- & - & 5.5 & -- \\
\hline Cs & 3.71 & - & 5.61 & -- & -. & - & 4.07 & -- & - & -- & 2.77 & .. \\
\hline Hf & 4.97 & - & 5.84 & -- & -. & -- & 3.87 & -- & -- & - & 12.4 & -- \\
\hline $\mathrm{Sb}$ & 0.364 & -- & 0.223 & -- & - & -- & 0.218 & -- & -- & -- & 0.420 & -- \\
\hline Ta & 1.22 & -- & 1.46 & -- & -. & - & 0.840 & -- & -- & -- & 1.83 & -- \\
\hline Th & 20.5 & -- & 21.7 & -- & - & -- & 13.2 & -- & - & -- & 39.9 & -- \\
\hline $\mathrm{U}$ & 5.06 & -- & 3.88 & -- & - & -- & 3.28 & -- & -- & -- & 8.7 & -- \\
\hline $\mathrm{Zn}$ & 76.3 & -- & 68.5 & -- & -. & -- & 57.6 & -- & -- & -. & 94.2 & -- \\
\hline Sc & 16.1 & - & 5.94 & -. & -. & -- & 7.35 & -- & -- & -- & 8.83 & -- \\
\hline $\mathrm{La}$ & 44 & -- & 60.2 & -. & -. & -. & 43.5 & -- & -- & -- & 92 & -. \\
\hline $\mathrm{Ce}$ & 93.6 & -- & 118 & -- & -. & -. & 86.3 & -- & - & -. & 195 & -- \\
\hline Nd & 36 & -- & 42.3 & -- & - & -- & 29.5 & -- & -- & -- & 71.4 & -- \\
\hline $\mathrm{Sm}$ & 6.64 & -- & 7.65 & -- & - & -. & 5.15 & -. & -- & -- & 12 & -. \\
\hline $\mathrm{Eu}$ & 1.34 & -- & 1.36 & -- & -- & -- & 1.12 & -- & -- & -- & 2.03 & - \\
\hline Gd & 5.66 & -- & 6.20 & -- & -. & -- & 3.72 & -- & -- & - & 8.8 & - \\
\hline $\mathrm{Tb}$ & 0.711 & -- & 0.718 & -. & -- & -- & 0.440 & -- & -- & -- & 1.1 & -- \\
\hline $\mathrm{Tm}$ & 0.366 & -- & 0.307 & -- & -. & -- & 0.209 & -- & -- & -- & 0.508 & -- \\
\hline $\mathrm{Yb}$ & 2.18 & -- & 1.73 & -- & -- & -- & 1.26 & -- & -- & -- & 3.07 & - \\
\hline $\mathrm{Lu}$ & 0.320 & - & 0.250 & -- & -. & -- & 0.188 & -- & -- & -- & 0.438 & -- \\
\hline
\end{tabular}


Table 4. Chemical compositions of middle Tertiary ash-flow tuffs in the White River Narrows area, Nevada-Continued.

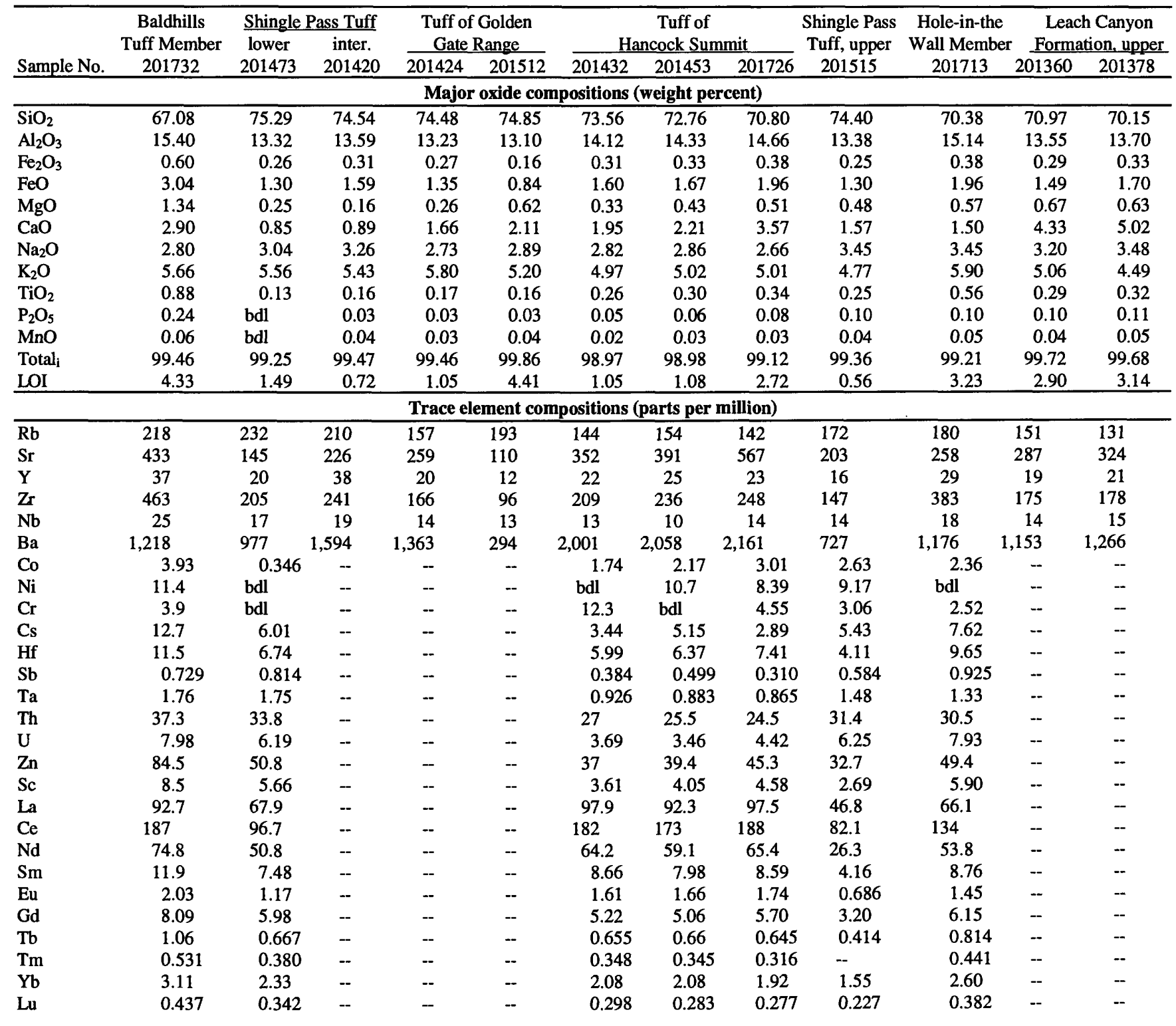


Table 4. Chemical compositions of middle Tertiary ash-flow tuffs in the White River Narrows area, Nevada-Continued.

\begin{tabular}{|c|c|c|c|c|c|c|c|c|c|c|c|c|}
\hline \multirow{2}{*}{ Sample No. } & \multirow{2}{*}{\multicolumn{2}{|c|}{$\begin{array}{c}\text { Leach Canyon } \\
\text { Formation, upper }\end{array}$}} & \multicolumn{7}{|c|}{ Condor Canyon Formation } & \multirow{2}{*}{$\begin{array}{c}\text { Pahranagat } \\
\text { Formation } \\
201707\end{array}$} & \multirow{2}{*}{$\begin{array}{c}\text { Harmony } \\
\text { Hills Tuff } \\
201368 \\
\end{array}$} & \multirow{2}{*}{$\begin{array}{c}\text { Hiko } \\
\text { Tuff } \\
201367 \\
\end{array}$} \\
\hline & & & \multicolumn{2}{|c|}{ Swett Member } & \multicolumn{5}{|c|}{ Bauers Tuff Member } & & & \\
\hline \multicolumn{13}{|c|}{ Major oxide compositions (weight percent) } \\
\hline $\mathrm{Al}_{2} \mathrm{O}_{3}$ & 14.31 & 13.55 & 14.52 & 16.26 & 14.98 & 13.58 & 14.39 & 14.38 & 14.88 & 13.23 & 14.20 & 14.47 \\
\hline $\mathrm{Fe}_{2} \mathrm{O}_{3}$ & 0.32 & 0.26 & 0.26 & 0.30 & 0.26 & 0.22 & 0.26 & 0.25 & 0.26 & 0.21 & 0.79 & 0.31 \\
\hline $\mathrm{FeO}$ & 1.61 & 1.34 & 1.33 & 1.51 & 1.33 & 1.14 & 1.31 & 1.27 & 1.32 & 1.09 & 4.05 & 1.59 \\
\hline $\mathrm{Na}_{2} \mathrm{O}$ & 3.45 & 3.21 & 3.27 & 2.56 & 3.80 & 3.63 & 3.81 & 3.68 & 3.75 & 3.06 & 2.89 & 3.24 \\
\hline $\mathrm{K}_{2} \mathrm{O}$ & 4.82 & 5.12 & 6.00 & 4.89 & 5.83 & 5.64 & 5.59 & 5.75 & 5.52 & 5.59 & 3.33 & 5.18 \\
\hline $\mathrm{TiO}_{2}$ & 0.32 & 0.28 & 0.36 & 0.39 & 0.32 & 0.28 & 0.31 & 0.30 & 0.32 & 0.19 & 0.66 & 0.32 \\
\hline $\mathrm{P}_{2} \mathrm{O}_{5}$ & 0.08 & 0.10 & 0.06 & 0.03 & 0.08 & 0.05 & 0.03 & 0.05 & 0.06 & bdl & 0.30 & 0.14 \\
\hline $\mathrm{MnO}$ & 0.05 & 0.04 & 0.04 & 0.04 & 0.04 & 0.04 & 0.04 & 0.05 & 0.04 & 0.06 & 0.07 & 0.04 \\
\hline Total $_{i}$ & 99.65 & 99.43 & 99.79 & 99.81 & 99.57 & 99.38 & 99.96 & 99.38 & 99.20 & 99.30 & 99.69 & 99.75 \\
\hline LOI & 0.92 & 1.86 & 3.24 & 8.03 & 0.61 & 1.31 & 1.18 & 0.49 & 0.94 & 0.94 & 3.46 & 3.55 \\
\hline $\mathrm{Zr}$ & 190 & 157 & 296 & 324 & 299 & 259 & 292 & 285 & 282 & 129 & 186 & 156 \\
\hline $\mathrm{Nb}$ & 12 & 12 & 16 & 15 & 15 & 17 & 17 & 16 & 13 & 15 & 10 & 15 \\
\hline Ba & 1,098 & 876 & 1,157 & 1,001 & 1,742 & 1,047 & 1,493 & 1,400 & 1,331 & 544 & 994 & 857 \\
\hline Co & 3.35 & - & - & -- & - & -. & - & 1.41 & 1.32 & 1.22 & - & - \\
\hline $\mathrm{Ni}$ & 5.0 & - & -- & - & - & -- & - & 13 & 13 & bdl & -- & -- \\
\hline $\mathrm{Cr}$ & 4.72 & - & - & - & -- & -- & - & 7.85 & bdl & 1.48 & -- & - \\
\hline Cs & 3.26 & - & -- & -- & -- & -- & -. & 5.52 & 3.64 & 5.21 & -. & -- \\
\hline Hf & 5.11 & -- & -- & -- & -- & -- & -. & 8.27 & 8.35 & 4.18 & -- & -- \\
\hline $\mathrm{Sb}$ & 0.367 & -- & -- & -. & -- & -- & -- & 0.801 & 0.832 & 0.375 & -- & -- \\
\hline $\mathrm{Ta}$ & 1.43 & -- & -- & -- & -- & -- & -- & 1.37 & 1.26 & 1.19 & -- & -- \\
\hline Th & 27.4 & -- & -- & -- & -- & -- & -- & 35.6 & 33.1 & 17.7 & -- & -- \\
\hline $\mathrm{U}$ & 4.17 & -- & -- & -- & -- & -- & -- & 7.27 & 8.06 & 3.57 & -- & -- \\
\hline $\mathrm{Tm}$ & 0.254 & -- & -- & - & - & -- & -- & 0.352 & 0.333 & 0.276 & - & - \\
\hline $\mathrm{Yb}$ & 1.55 & - & -- & -- & -- & -- & -- & 2.20 & 2.09 & 1.70 & - & -- \\
\hline $\mathrm{Lu}$ & 0.231 & -. & -- & -. & - & -- & -- & 0.319 & 0.292 & 0.248 & -- & -- \\
\hline
\end{tabular}


Table 5. Average major oxide, CIPW normative, and trace-element compositions (computed from data in tables 3 and 4) of middle Tertiary ash-flow tuffs in the Seaman Range, Nevada.

[ $\mathrm{FeO} / \mathrm{FeO}^{*}$ (total iron as $\mathrm{FeO}$ ) is adjusted to 0.85 . Major oxide analyses are normalized to 100 percent, volatile free. LOI, loss on ignition; bdl, below detection limit; \pm , calculated standard deviation. $n$ is number of samples used in calculation of mean and standard deviation]

\begin{tabular}{|c|c|c|c|c|c|c|}
\hline & $\begin{array}{c}\text { Wah Wah Springs } \\
\text { Formation }\end{array}$ & Lund Formation & $\begin{array}{c}\text { Petroglyph Cliff } \\
\text { Ignimbrite }\end{array}$ & Monotony Tuff & $\begin{array}{l}\text { Isom Formation, } \\
\text { Baldhills Member }\end{array}$ & $\begin{array}{l}\text { Shingle Pass Tuff, } \\
\text { lower cooling unit }\end{array}$ \\
\hline $\bar{n}$ & 1 & 7 & 4 & 7 & 6 & 3 \\
\hline $\mathrm{Al}_{2} \mathrm{O}_{3}$ & 15.64 & $15.64 \pm 0.57$ & $15.83 \pm 0.52$ & $15.37 \pm 0.20$ & $15.61 \pm 0.30$ & $13.40 \pm 0.19$ \\
\hline $\mathrm{Fe}_{2} \mathrm{O}_{3}$ & 0.86 & $0.63 \pm 0.13$ & $0.71 \pm 0.09$ & $0.44 \pm 0.06$ & $0.62 \pm 0.07$ & $0.27 \pm 0.02$ \\
\hline $\mathrm{FeO}$ & 4.37 & $3.21 \pm 0.67$ & $3.65 \pm 0.45$ & $2.25 \pm 0.28$ & $3.16 \pm 0.35$ & $1.39 \pm 0.08$ \\
\hline $\mathrm{Na}_{2} \mathrm{O}$ & 2.99 & $2.66 \pm 0.16$ & $3.19 \pm 0.21$ & $2.46 \pm 0.10$ & $3.32 \pm 0.27$ & $3.01 \pm 0.11$ \\
\hline $\mathrm{K}_{2} \mathrm{O}$ & 3.50 & $3.96 \pm 0.46$ & $3.72 \pm 0.51$ & $3.89 \pm 0.24$ & $5.63 \pm 0.33$ & $5.60 \pm 0.03$ \\
\hline $\mathrm{TiO}_{2}$ & 0.65 & $0.57 \pm 0.07$ & $0.85 \pm 0.05$ & $0.32 \pm 0.05$ & $0.86 \pm 0.04$ & $0.14 \pm 0.01$ \\
\hline $\mathrm{P}_{2} \mathrm{O}_{5}$ & 0.18 & $0.18 \pm 0.03$ & $0.24 \pm 0.05$ & $0.08 \pm 0.01$ & $0.22 \pm 0.03$ & bdl \\
\hline $\mathrm{MnO}$ & 0.07 & $0.05 \pm 0.02$ & $0.07 \pm 0.03$ & $0.04 \pm 0.01$ & $0.07 \pm 0.02$ & bdl \\
\hline$\underline{\mathrm{LOI}}$ & 1.47 & $3.04 \pm 0.49$ & $2.48 \pm 0.49$ & $4.07 \pm 1.00$ & $2.28 \pm 1.18$ & $1.42 \pm 0.42$ \\
\hline$a b$ & 25.34 & 22.47 & 27.00 & 20.79 & 28.13 & 25.44 \\
\hline an & 18.90 & 17.62 & 17.61 & 16.07 & 10.50 & 4.70 \\
\hline di & 3.55 & 0.00 & 0.00 & 0.00 & 0.00 & 0.00 \\
\hline hy & 10.66 & 7.64 & 8.08 & 6.43 & 6.23 & 2.72 \\
\hline $\mathrm{mt}$ & 1.24 & 0.91 & 1.04 & 0.64 & 0.90 & 0.39 \\
\hline il & 1.24 & 1.08 & 1.61 & 0.62 & 1.64 & 0.27 \\
\hline ap & 0.44 & 0.42 & 0.57 & 0.19 & 0.52 & 0.00 \\
\hline \multicolumn{7}{|c|}{ Trace element compositions (parts per million) } \\
\hline $\bar{n}$ & 1 & 27 & 7 & 9 & 11 & 11 \\
\hline $\mathrm{Rb}$ & 126 & $156 \pm 22$ & $110 \pm 25$ & $124 \pm 11$ & $209 \pm 12$ & $223 \pm 7$ \\
\hline $\mathrm{Sr}$ & 530 & $456 \pm 63$ & $476 \pm 97$ & $370 \pm 25$ & $425 \pm 62$ & $144 \pm 13$ \\
\hline $\mathbf{Y}$ & 24 & $19 \pm 3$ & $32 \pm 5$ & $17 \pm 4$ & $39 \pm 3$ & $33 \pm 6$ \\
\hline $\mathbf{Z r}$ & 157 & $189 \pm 22$ & $311 \pm 25$ & $139 \pm 9$ & $493 \pm 29$ & $204 \pm 11$ \\
\hline Hf & 4.97 & $5.89 \pm 0.22$ & $7.36 \pm 0.61$ & $3.93 \pm 0.15$ & $12.0 \pm 0.64$ & $6.92 \pm 0.30$ \\
\hline $\mathrm{Sb}$ & 0.364 & $0.262 \pm 0.06$ & $0.377 \pm 0.06$ & $0.174 \pm 0.04$ & $0.575 \pm 0.22$ & $0.965 \pm 0.14$ \\
\hline $\mathrm{Ta}$ & 1.22 & $1.37 \pm 0.12$ & $1.32 \pm 0.12$ & $0.905 \pm 0.13$ & $1.80 \pm 0.05$ & $1.71 \pm 0.04$ \\
\hline Th & 20.5 & $20.2 \pm 1.20$ & $15.5 \pm 1.36$ & $13.4 \pm 1.08$ & $32.6 \pm 1.55$ & $33.3 \pm 0.90$ \\
\hline $\mathrm{U}$ & 5.06 & $3.88 \pm 0.43$ & $3.90 \pm 0.21$ & $3.53 \pm 0.41$ & $8.34 \pm 0.51$ & $6.50 \pm 0.51$ \\
\hline $\mathbf{Z n}$ & 76.3 & $62.2 \pm 6.72$ & $66.3 \pm 15.5$ & $50.3 \pm 5.40$ & $89.4 \pm 6.86$ & $50.3 \pm 2.73$ \\
\hline Sc & 16.1 & $8.14 \pm 3.28$ & $13.2 \pm 0.81$ & $6.52 \pm 0.82$ & $8.67 \pm 0.23$ & $5.71 \pm 0.17$ \\
\hline La & 44.0 & $57.2 \pm 3.57$ & $52.7 \pm 4.90$ & $46.0 \pm 3.94$ & $92.4 \pm 0.50$ & $71.1 \pm 3.88$ \\
\hline $\mathrm{Ce}$ & 93.6 & $115 \pm 6.02$ & $107 \pm 7.81$ & $90.0 \pm 8.12$ & $191 \pm 5.65$ & $126 \pm 28.2$ \\
\hline $\mathrm{Nd}$ & 36.0 & $43.4 \pm 2.48$ & $46.4 \pm 4.55$ & $34.6 \pm 3.68$ & $73.1 \pm 2.41$ & $52.2 \pm 2.96$ \\
\hline $\mathrm{Sm}$ & 6.64 & $7.39 \pm 0.47$ & $8.49 \pm 0.76$ & $5.54 \pm 0.39$ & $12.0 \pm 0.07$ & $8.16 \pm 0.68$ \\
\hline $\mathrm{Eu}$ & 1.34 & $1.39 \pm 0.11$ & $1.64 \pm 0.11$ & $1.19 \pm 0.05$ & $2.03 \pm 0.00$ & $1.25 \pm 0.12$ \\
\hline Gd & 5.66 & $5.63 \pm 0.35$ & $6.54 \pm 0.79$ & $3.97 \pm 0.19$ & $8.45 \pm 0.50$ & $4.02 \pm 3.49$ \\
\hline $\mathrm{Tb}$ & 0.711 & $0.682 \pm 0.04$ & $0.939 \pm 0.09$ & $0.475 \pm 0.04$ & $1.08 \pm 0.03$ & $0.790 \pm 0.11$ \\
\hline $\mathrm{Tm}$ & 0.366 & $0.304 \pm 0.04$ & $0.503 \pm 0.06$ & $0.235 \pm 0.02$ & $0.520 \pm 0.02$ & $0.494 \pm 0.00$ \\
\hline $\mathrm{Yb}$ & 2.18 & $1.76 \pm 0.21$ & $3.14 \pm 0.39$ & $1.48 \pm 0.21$ & $3.09 \pm 0.03$ & $2.77 \pm 0.38$ \\
\hline $\mathrm{Lu}$ & 0.320 & $0.255 \pm 0.03$ & $0.443 \pm 0.06$ & $0.216 \pm 0.03$ & $0.438 \pm 0.00$ & $0.400 \pm 0.05$ \\
\hline
\end{tabular}


Table 5. Average major oxide, CIPW normative, and trace-element compositions (computed from data in tables 3 and 4) of middle Tertiary ash-flow tuffs in the Seaman Range, Nevada-Continued.

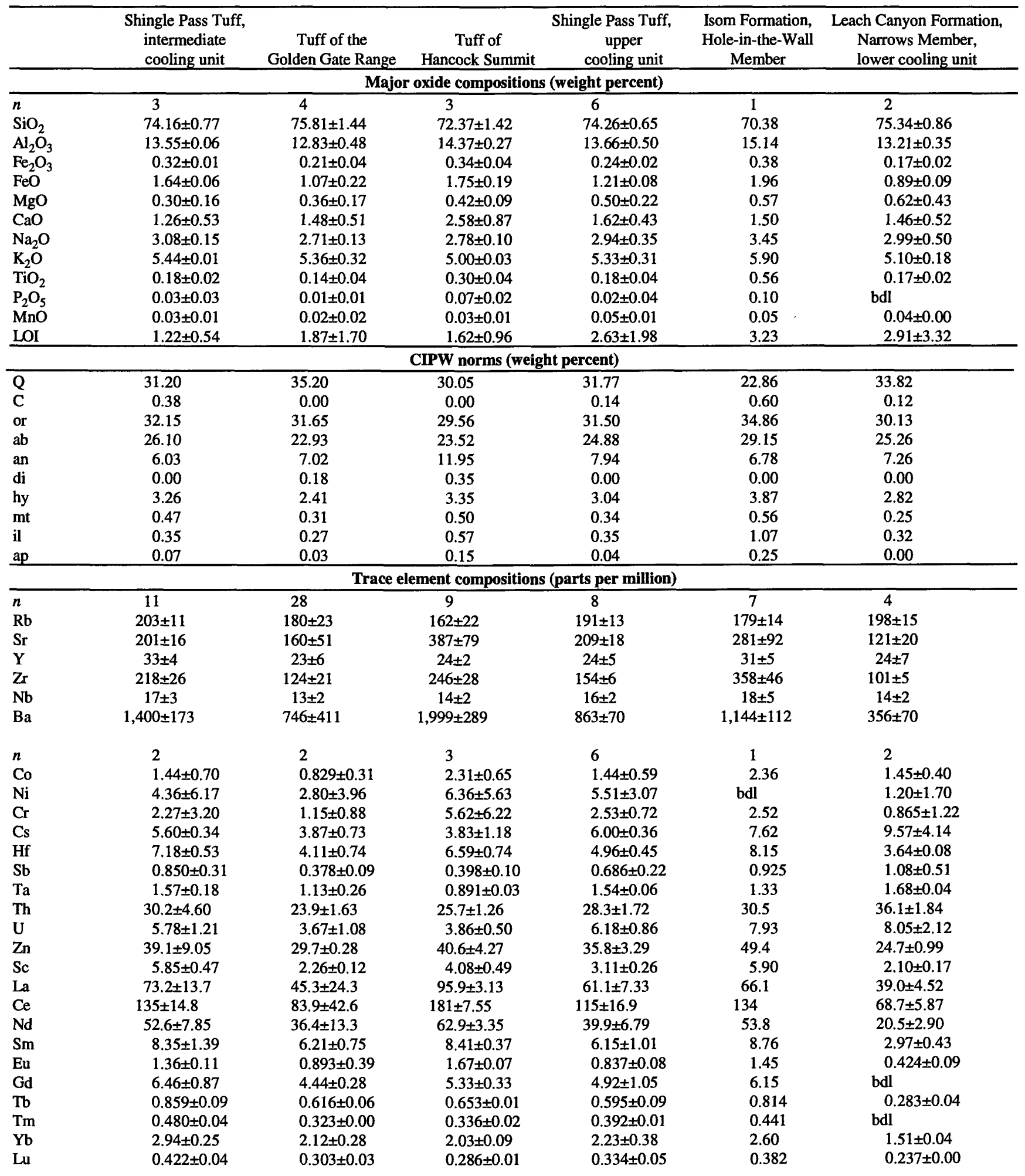


Table 5. Average major oxide, CIPW normative, and trace-element compositions (computed from data in tables 3 and 4) of middle Tertiary ash-flow tuffs in the Seaman Range, Nevada-Continued.

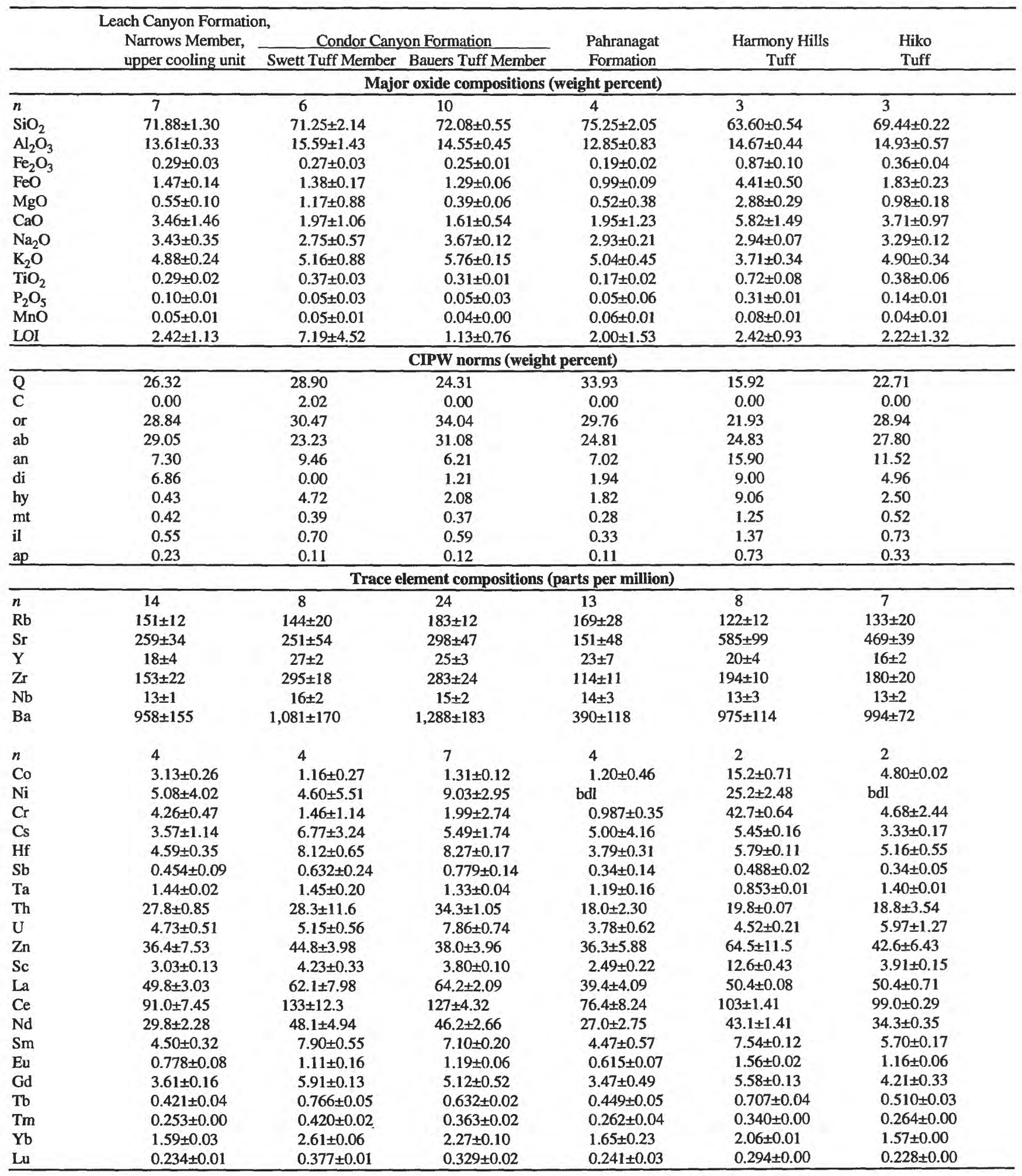






Figure 8. Uppermost part of the upper cooling unit of the Narrows Member (LCU) of the Leach Canyon Formation, the Swett Tuff Member of the Condor Canyon Formation (CS), the Bauers Tuff Member of the Condor Canyon Formation(CB), the Pahranagat Formation (PF), and the Harmony Hills Tuff (HH). View to the southwest. Section is on the west side of White River Narrows midway along its length. Note vitrophyres several meters thick at the base of the Swett Tuff and Bauers Tuff Members.

and lithic and pumice contents), and are characterized by compositional attributes similar to those of subalkaline continental interior subduction-related volcanic rocks (Macdonald and others, 1992).

Pearce and others (1984) recognized that granitoid rocks generated in various tectonic settings have distinctive geochemical signatures on trace-element discriminant diagrams. Trace-element abundance variations in coeval volcanic and plutonic rocks generated in a given terrane should be similar. Consequently, compositions of tuffs of the Narrows area can be compared to the tectonic setting-trace element grids developed by Pearce and others (1984). Traceelement data for the tuffs plot in the volcanic arc field, near its boundary with within-plate compositions, on these diagrams (fig. 10). Compositions of Narrows area tuffs plotting near the within-plate field may indicate that the associated magmas had a significant crustal component. Gill (1981) indicated that $\mathrm{Ba} / \mathrm{Nb}$ ratios of modern arc rocks are greater than $26 . \mathrm{Ba} / \mathrm{Nb}$ ratios for all tuffs of the Narrows area are greater than 26 and for most units are greater than 50. Major oxide compositions for tuffs of the Narrows area follow a calc-alkaline trend on an AFM diagram (fig. 11). All of these compositional features support the inference that tuffs of the Narrows area are subduction-related continental arc magmas. Furthermore, the compositions of ash-flow tuffs of the southeastern Great Basin are similar to those reported by Macdonald and others (1992) for obsidians from subduction-related volcanic centers in continental interior settings. Differences between the two data sets reflect the fact that the data set of Macdonald and others (1992) is biased toward rhyolitic compositions. As a consequence, some of the dacitic ash-flow tuffs of the southeastern Great Basin are characterized by compositions somewhat less evolved, and having relatively lower and higher abundances of the incompatible and compatible elements, respectively, than those of the obsidians.

Zirconium abundances for most of the tuffs of the Narrows area approximate the experimentally determined (Watson and Harrison, 1983) zirconium saturation threshold of several hundred parts per million. Thus, magmas represented by these tuffs did not equilibrate with peralkaline liquids nor did they equilibrate at a temperature greater than about $860^{\circ} \mathrm{C}$. Zirconium abundances in the Baldhills and Hole-inthe-Wall Members of the Isom Formation, however, are greater than $350 \mathrm{ppm}$. These tuffs have compositions with alkaline tendencies, and they may have equilibrated with peralkaline liquids and (or) at temperatures greater than about $860^{\circ} \mathrm{C}$. 



Figure 9. Variation diagrams showing abundances of selected major oxides and trace elements in ash-flow tuffs in the White River Narrows area, Nevada. Abundances given in tables 3 and 4. 

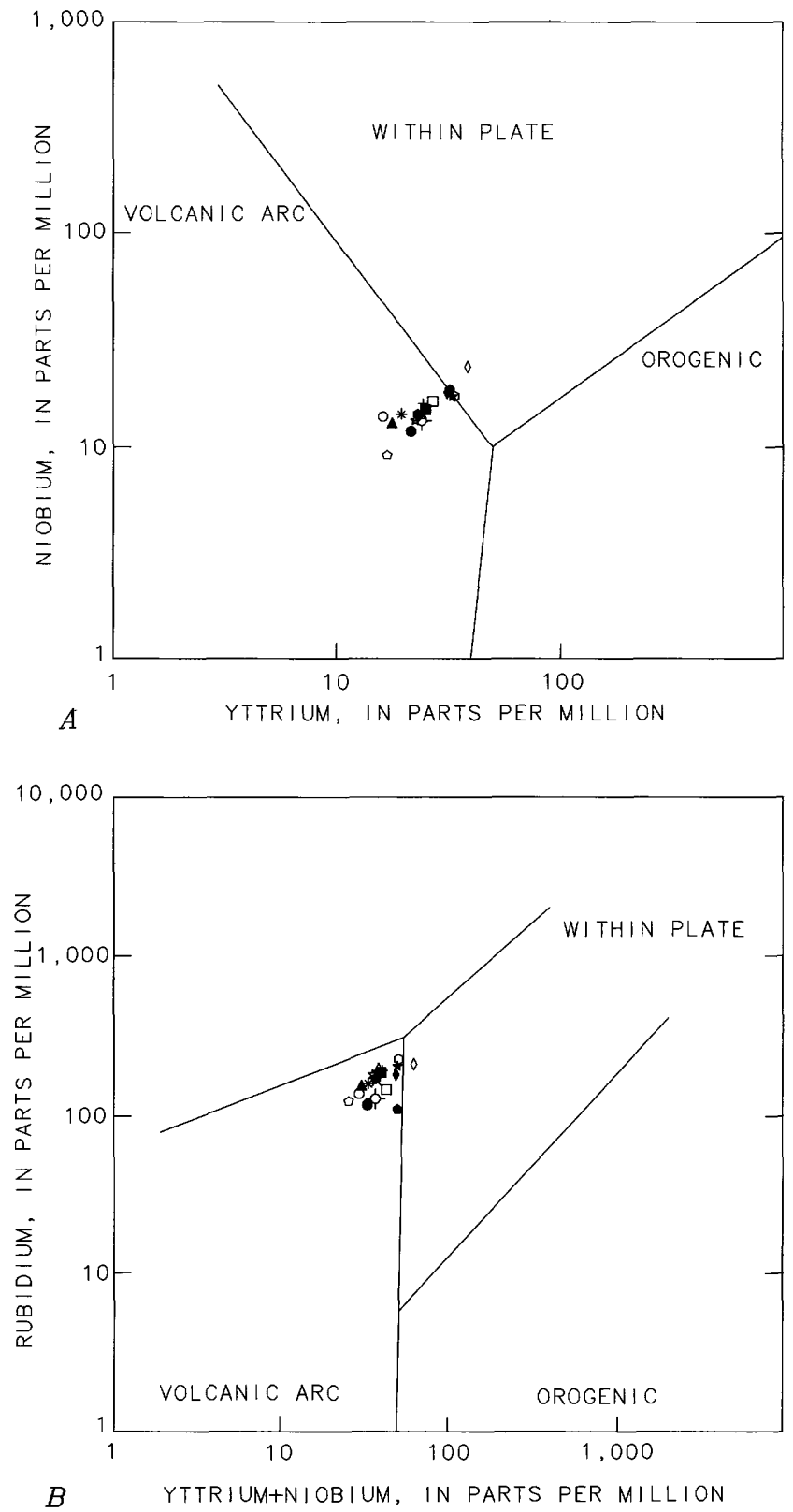

Figure 10. Trace element-tectonic setting discrimination variation diagrams showing average compositions of ash-flow tuffs in the White River Narrows area, Nevada. Tectonic setting-composition boundaries from Pearce and others (1984); compositions from table 5 . Symbols as in figure 2 . $A$, Niobium versus yttrium. $B, \mathrm{Ru}-$ bidium versus yttrium plus niobium.

Feldspar-melt distribution coefficients for strontium, barium, and rubidium (Hanson, 1978) are such that feldspar fractionation preferentially removes strontium and then barium from the melt phase relative to rubidium such that residual liquids become progressively enriched in rubidium relative to barium and strontium. Rubidium abundances increase systematically with increasing $\mathrm{SiO}_{2}$ (fig. 9) and deceasing strontium abundances (fig. 12). Rubidium enrichment,

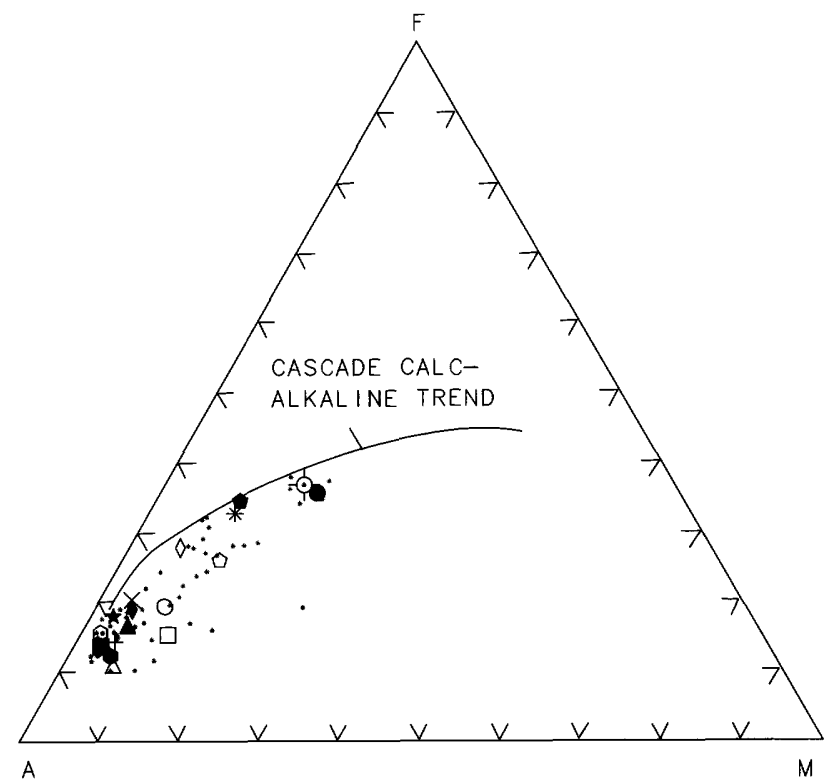

Figure 11. Ternary AFM $\left(\mathrm{Al}_{2} \mathrm{O}_{3}-\mathrm{FeO}-\mathrm{MgO}\right)$ diagram showing compositions of ash-flow tuffs in the White River Narrows area, Nevada. Symbols as in figure 2. Dots show all data from tables 3 and 4; other symbols show average tuff compositions from table 5. Cascade calc-alkaline trend line from Irvine and Baragar (1971).

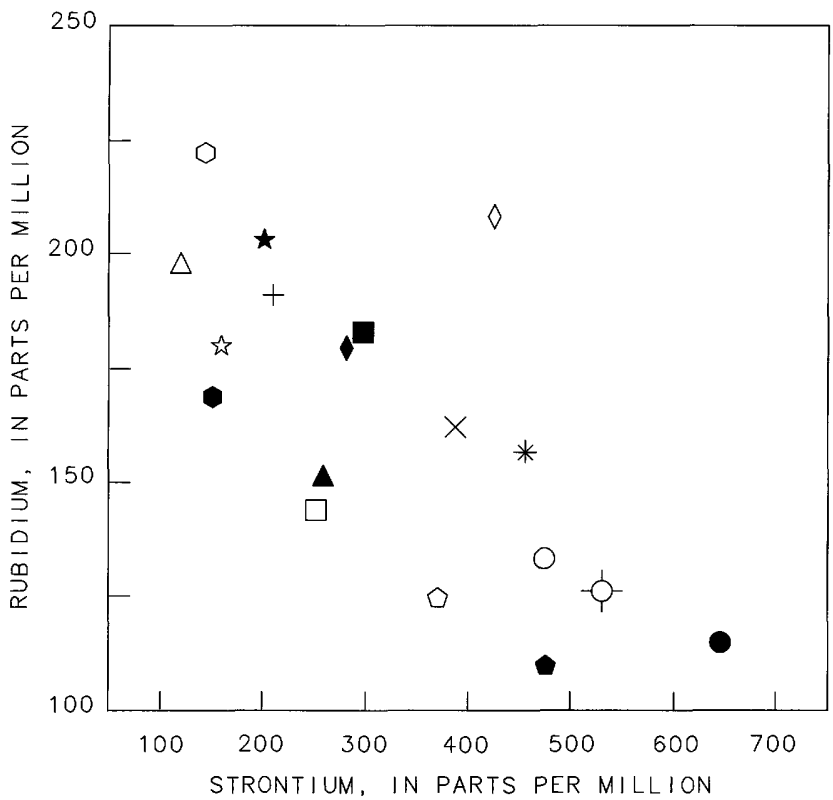

Figure 12. Variation diagram showing the average rubidium and strontium abundances in ash-flow tuffs in the White River Narrows area, Nevada. Symbols as in figure 2; abundances from table 5.

relative to strontium and barium abundances (fig. 13), in tuffs of the Narrows area is not as pronounced as in some high-silica rhyolites, in which the abundance of rubidium may greatly exceed the abundances of strontium and barium (Hildreth, 1979; Duffield and du Bray, 1990). Barium abundances in 


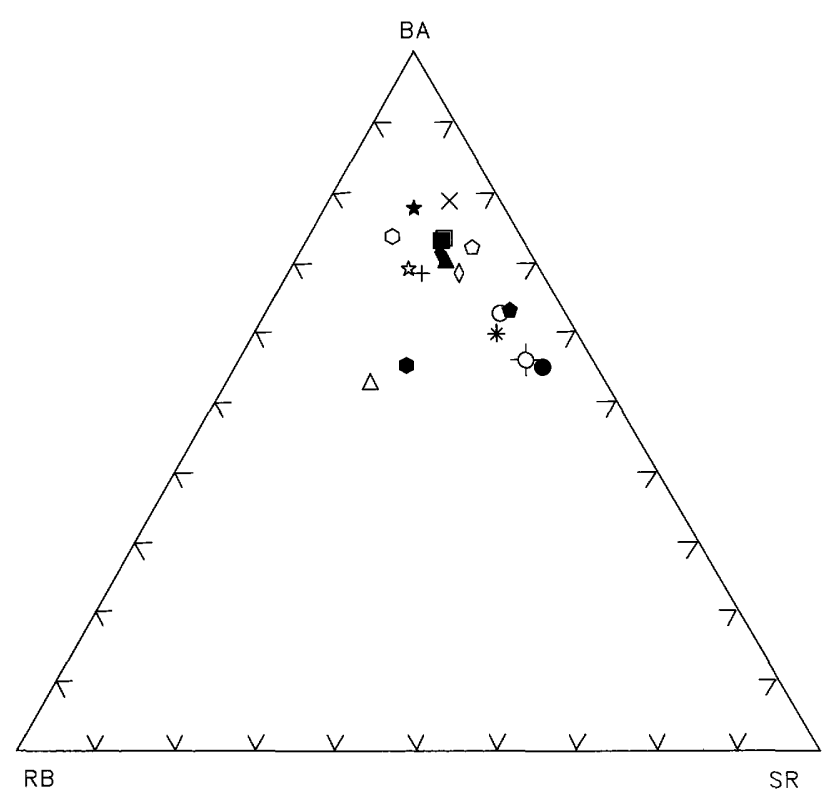

Figure 13. Ternary variation diagram showing the average relative proportions of rubidium, barium, and strontium in ash-flow tuffs in the White River Narrows area, Nevada. Symbols as in figure 2; abundances from table 5 .

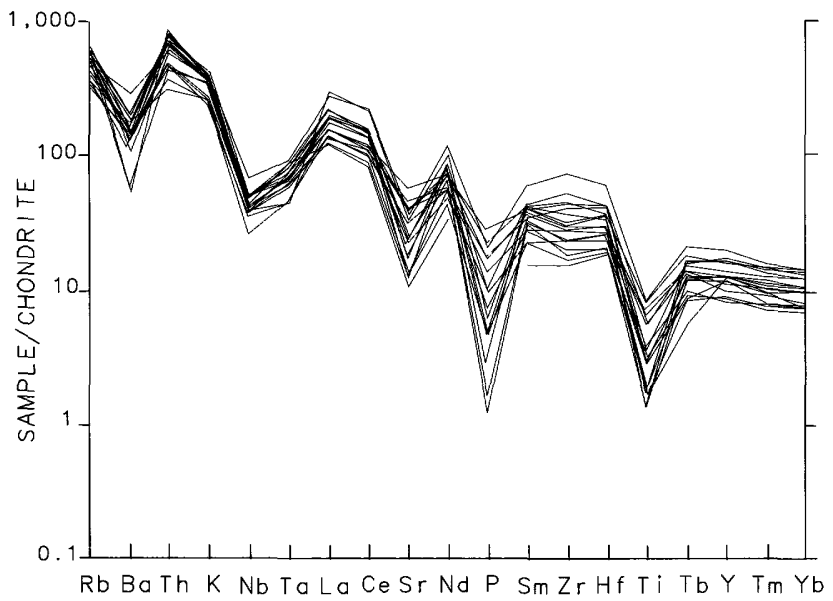

Figure 14. Chondrite-normalized (after Thompson and others, 1983) extended trace-element diagram showing average compositions of ash-flow tuffs in the White River Narrows area, Nevada. Trace elements are arranged in order of increasing compatibility to the right. Trace-element abundances from table 5 .

most of the analyzed tuffs are elevated, considerably in some cases, relative to barium abundances in obsidians from subduction-related volcanic rocks (Macdonald and others, 1992). $\mathrm{Rb} / \mathrm{Sr}$ ratios range from a low of 0.18 in the Harmony Hills Tuff to a more evolved value of 1.64 in the lower ashflow tuff of the Leach Canyon Formation; the average $\mathrm{Rb} / \mathrm{Sr}$ value for the 18 analyzed tuffs is $0.68 \pm 0.45$.

Chondrite-normalized extended trace-element patterns (table 5, fig. 14) for tuffs of the Narrows area are gently



Figure 15. Chondrite-normalized (after Anders and Ebihara, 1982) rare earth element diagram showing average compositions of ash-flow tuffs in the White River Narrows area, Nevada. Rare earth element abundances from table 5.

negatively sloping and relatively smooth and show superposed negative $\mathrm{Ba}, \mathrm{Nb}, \mathrm{Ta}, \mathrm{Sr}, \mathrm{P}$, and $\mathrm{Ti}$ anomalies. The barium and strontium anomalies probably reflect feldspar fractionation, whereas the phosphorous and titanium anomalies may indicate apatite and iron-titanium-oxide fractionation, respectively. A negative niobium-tantalum anomaly is considered (Wood and others, 1979; Gill, 1981; Pearce and others, 1984) to be an indication of subduction-related arc magmatism. The shape, slope, and abundance levels of chondrite-normalized extended trace-element patterns for tuffs of the Narrows area overlap those for the East-Central Nevada and Indian Peak volcanic fields (Gans and others, 1989; Best and Christiansen, 1991; Feeley and Grunder, 1991).

The most striking features of trace-element patterns for tuffs of the Narrows area are their parallelism and their relatively limited compositional range. In addition, patterns for samples from the composition profiles of individual stratigraphic units define remarkably narrow trace-element abundance ranges; compositional variation within each of the tuffs of the Narrows area is relatively limited (table 3). Indices of compositional evolution, abundances of $\mathrm{SiO}_{2}$ or rubidium, for instance, are poorly correlated with abundances of other oxides and trace elements shown in the trace-element diagram. The greatest amounts of compositional variation are among phosphorous, titanium, barium, and strontium and probably only reflect varying amounts of apatite, iron-titanium oxide, and plagioclase fractionation. Tuffs of the Isom compositional type are distinguished by the largest abundances of the most compatible trace elements (table 3, fig. 14). The most evolved tuffs, the Pahranagat Formation and the lower cooling unit of the Narrows Member of the Leach Canyon Formation, are distinguished by large negative barium anomalies that, again, probably reflect feldspar fractionation. 



YTTRIUM, IN PARTS PER MILLION ZIRCONIUM, IN PARTS PER MILLION NIOBIUM, IN PARTS PER MILLION BARIUM, IN PARTS PER MILLION 



Figure 16 (above and facing page). Stratigraphic compositional variation of ash-flow tuffs in the White River Narrows area, Nevada. Asterisks (*) represent data for samples collected without regard to vertical position within the indicated units; X's represent data for samples from composition profiles. Analytical uncertainty for oxide or element is shown by error bars in bottom right corner of plot. Units arranged from youngest (top) to oldest (bottom) in each plot. Unit designations as in figure 2. 


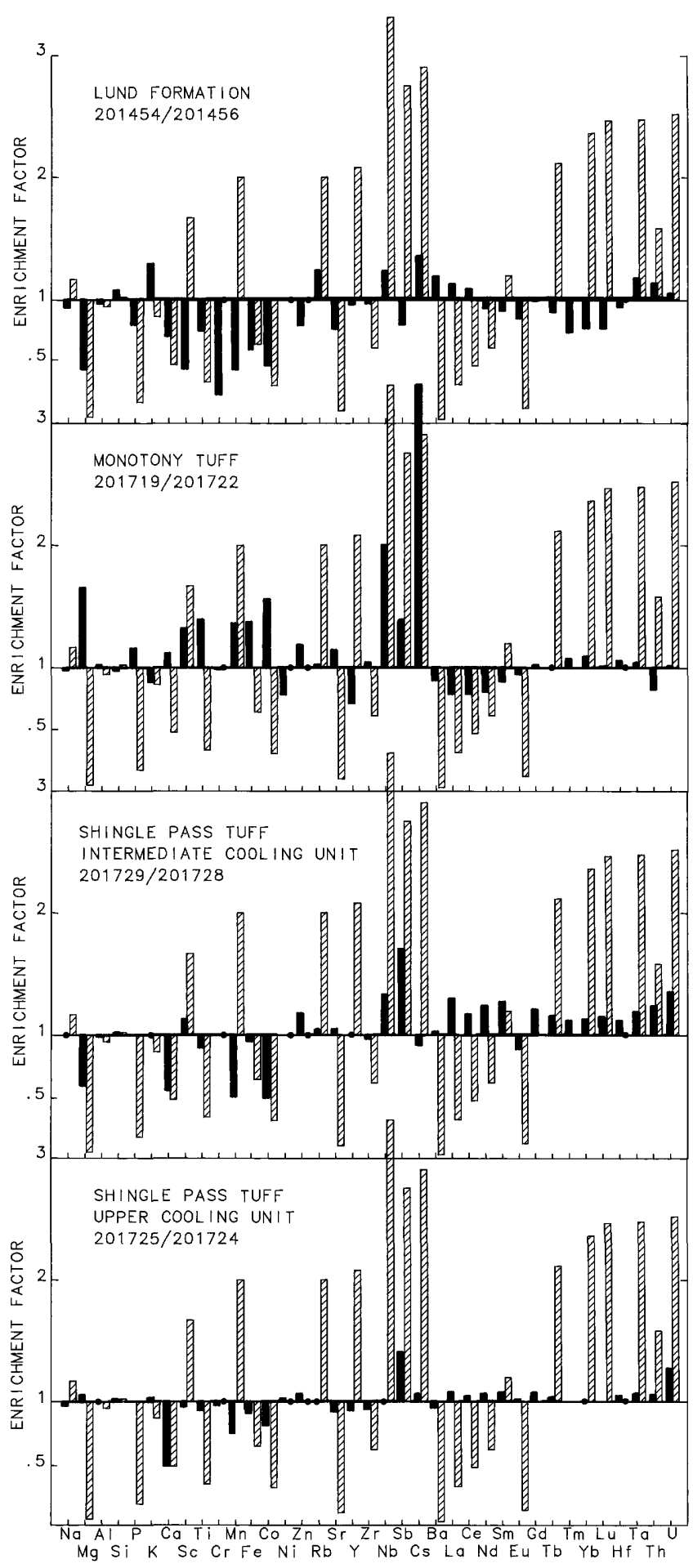

Average (table 5) chondrite-normalized rare earth element patterns for tuffs of the Narrows area (fig. 15), similar to the chondrite-normalized extended trace-element patterns, define a narrow compositional range; similarly, compositional variation within each of tuffs is relatively limited (table 3). The light rare earth element parts of the patterns are moderately negatively sloping, whereas the heavy rare earth element parts are only very gently negatively sloping; the

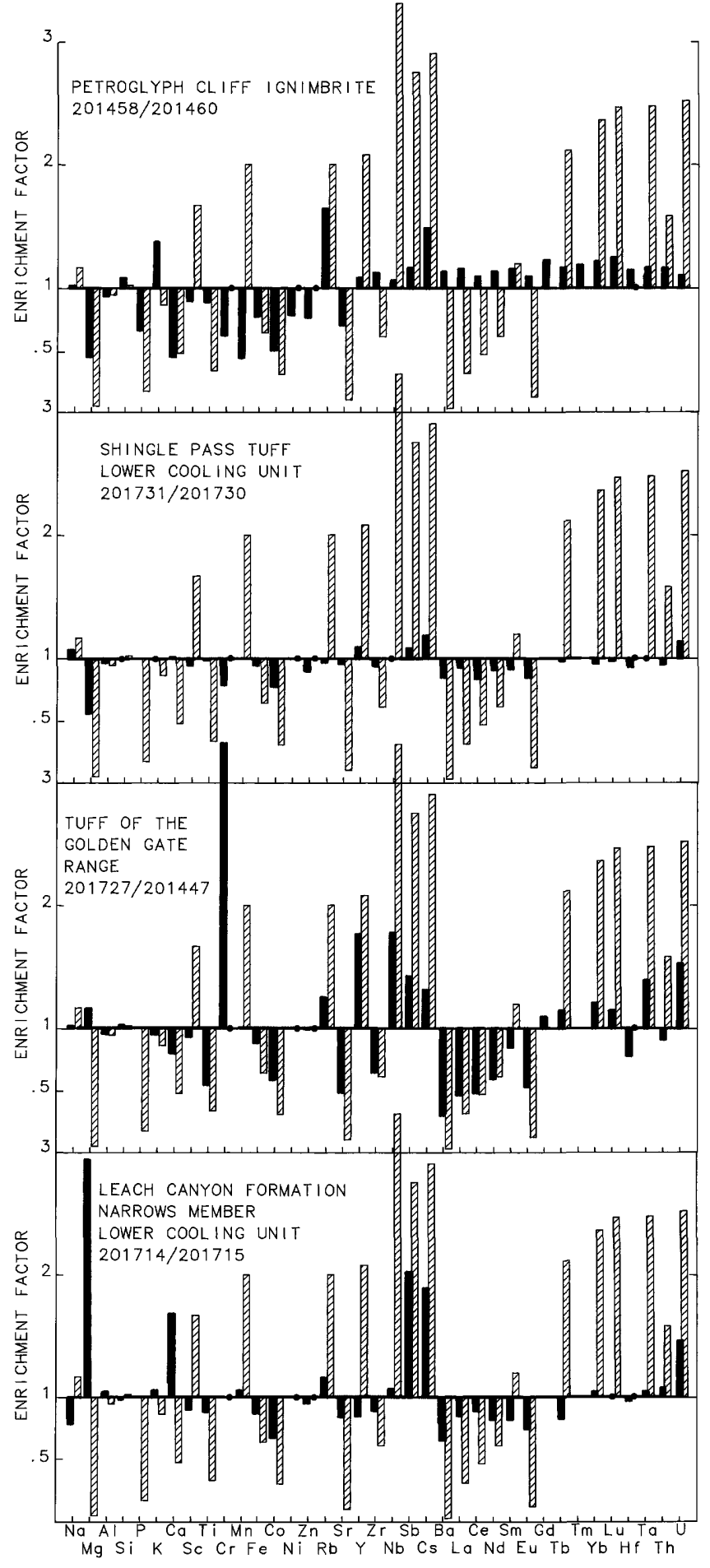

patterns include small negative europium anomalies of variable magnitude that probably result from modest amounts of feldspar fractionation (Hanson, 1978). Chondrite-normalized $\mathrm{La} / \mathrm{Lu}$ ratios range from 12.3 to 34.8 and average $19.5 \pm 4.9$, and total rare earth element contents range from 133.5 to 384.0 (average 233.9 \pm 65.3 ) ppm.

Systematic time-space-composition variations characterize ash-flow tuffs erupted from sources within the three 



Figure 17 (above and facing page). Enrichment-depletion factors (solid bars) for 14 ash-flow tuffs in the White River Narrows area, Nevada. Factors calculated from compositions of stratigraphically lowest and highest samples in composition profiles. Data for the Bishop Tuff are shown for comparison (diagonal-ruled bars). Dots on the baseline at a value of 1.0 indicate oxides or elements whose abundances are below detection limits or are identical within analytical uncertainty. Six-digit numbers in upper left corner of each plot indicate stratigraphically low and high samples (table 3 ), respectively.

caldera complexes of the southeastern Great Basin (fig. 16). Specifically, tuffs erupted from sources within the Indian Peak caldera complex, which reflect the earliest manifestation of voluminous middle Tertiary magmatism in the Narrows region, are characterized by distinctly lower abundances of $\mathrm{SiO}_{2}, \mathrm{~K}_{2} \mathrm{O}$, rubidium, and thorium and higher abundances of $\mathrm{Al}_{2} \mathrm{O}_{3}, \mathrm{FeO} *, \mathrm{MgO}, \mathrm{TiO}_{2}, \mathrm{P}_{2} \mathrm{O}_{5}$, strontium, cobalt, and scandium relative to tuffs erupted from younger sources in either the Central Nevada or Caliente caldera complexes. No systematic compositional differences are apparent between tuffs erupted from the Central Nevada or Caliente caldera complexes, though some systematic compositional variation with respect to age characterizes these tuffs. In particular, abundances of $\mathrm{SiO}_{2}, \mathrm{~K}_{2} \mathrm{O}$, rubidium, zinc, ytterbium, and tantalum generally decrease in progressively younger tuffs erupted from the these two caldera complexes.

\section{VERTICAL ZONATION}

Smith (1979) and Hildreth $(1979,1981)$, among others, have argued convincingly that most if not all large, highly evolved magma systems, particularly those associated with caldera-forming eruptions, are vertically compositionally zoned. Most zoned ash-flow tuffs are interpreted to represent eruption from vertically zoned reservoirs; the base and top of such tuffs are interpreted to represent the shallowest and deepest erupted levels, respectively, of the source reservoir. 
Table 6. Summary of enrichment and depletion relations for ash-flow tuff units exposed in the Seaman Range, Nevada.

[Numbers in the Enriched, Depleted, and Unchanged columns under the Early/Late heading indicate the number of units (of 14 total units) in which the abundance of the indicated oxide or element is enriched, depleted, or unchanged, respectively, in stratigraphically lowest sample versus that for highest sample. Similarly, numbers in the Enriched, Depleted, and Unchanged columns under the Transitions heading indicate the number of instances (of 29 total upsection within-unit transitions) in which the abundance of the indicated oxide or element is enriched, depleted, or unchanged, respectively, relative to that of the within-unit sample collected directly above. In both sets of columns, oxides and elements are arranged, from top to bottom, in order of decreasing enrichment in the top of the magma reservoir (stratigraphically low in the vertical section of each tuff) or, alternatively, in order of increasing enrichment in progressively lower parts of the magma reservoir (stratigraphically high in the composition profile of each tuff)]

\begin{tabular}{|c|c|c|c|c|c|c|c|}
\hline \multirow{2}{*}{$\begin{array}{l}\begin{array}{l}\text { Oxide or } \\
\text { element }\end{array} \\
\end{array}$} & \multicolumn{3}{|c|}{ Early/Late } & \multirow{2}{*}{$\begin{array}{l}\begin{array}{l}\text { Oxide or } \\
\text { element }\end{array} \\
\end{array}$} & \multicolumn{3}{|c|}{ Transitions } \\
\hline & Enriched & Depleted & Unchanged & & Enriched & Depleted & Unchanged \\
\hline $\mathbf{R b}$ & 13 & 1 & - & $\mathrm{Rb}$ & 19 & 4 & 6 \\
\hline $\mathrm{Ta}$ & 12 & 1 & 1 & $\mathrm{Ta}$ & 16 & 5 & 8 \\
\hline $\mathrm{Sb}$ & 12 & 2 & - & $\mathrm{SiO}_{2}$ & 19 & 9 & 1 \\
\hline $\mathrm{U}$ & 12 & 2 & - & Cs & 18 & 9 & 2 \\
\hline Cs & 11 & 3 & - & U & 16 & 9 & 4 \\
\hline $\mathrm{Tb}$ & 10 & 3 & 1 & $\mathrm{Ni}$ & 15 & 8 & 6 \\
\hline Gd & 9 & 2 & 1 & $\mathrm{La}$ & 13 & 6 & 10 \\
\hline $\mathrm{Yb}$ & 9 & 2 & 3 & Gd & 12 & 5 & 12 \\
\hline $\mathrm{Nb}$ & 8 & 3 & 3 & $\mathrm{Al}_{2} \mathrm{O}_{3}$ & 17 & 11 & 1 \\
\hline $\mathrm{MgO}$ & 9 & 5 & - & $\mathrm{Sb}$ & 17 & 12 & - \\
\hline $\mathrm{SiO}_{2}$ & 8 & 4 & 2 & MgO & 16 & 11 & 2 \\
\hline $\mathrm{K}_{2} \mathrm{O}$ & 8 & 4 & 2 & $\mathrm{~Tb}$ & 12 & 7 & 10 \\
\hline Th & 8 & 5 & 1 & $\mathrm{Yb}$ & 11 & 6 & 12 \\
\hline $\mathbf{L a}$ & 8 & 5 & 1 & $\mathrm{Lu}$ & 6 & 2 & 21 \\
\hline $\mathrm{Ce}$ & 8 & 5 & 1 & $\mathrm{Nb}$ & 8 & 5 & 16 \\
\hline $\mathrm{Sm}$ & 8 & 5 & 1 & $\mathrm{MnO}$ & 11 & 9 & 9 \\
\hline $\mathrm{Tm}$ & 6 & 3 & 5 & $\mathrm{Nd}$ & 13 & 11 & 5 \\
\hline $\mathrm{Zn}$ & 8 & 6 & - & $\mathrm{Zn}$ & 11 & 9 & 9 \\
\hline $\mathrm{Nd}$ & 8 & 6 & - & Th & 10 & 8 & 11 \\
\hline $\mathrm{Al}_{2} \mathrm{O}_{3}$ & 7 & 6 & 1 & Sm & 10 & 8 & 11 \\
\hline $\mathrm{Hf}$ & 7 & 6 & 1 & $\mathrm{Y}$ & 10 & 9 & 10 \\
\hline $\mathrm{Lu}$ & 7 & 6 & 1 & $\mathrm{Hf}$ & 10 & 9 & 10 \\
\hline $\mathrm{Ni}$ & 3 & 2 & 9 & $\mathrm{Ce}$ & 10 & 10 & 9 \\
\hline Sc & 7 & 7 & - & $\mathrm{Eu}$ & 12 & 12 & 5 \\
\hline $\mathrm{Eu}$ & 7 & 7 & - & $\mathrm{K}_{2} \mathrm{O}$ & 14 & 15 & - \\
\hline $\mathrm{MnO}$ & 6 & 6 & 2 & $\mathrm{TiO}_{2}$ & 10 & 12 & 7 \\
\hline Y & 6 & 6 & 2 & $\mathrm{Na}_{2} \mathrm{O}$ & 12 & 14 & 3 \\
\hline $\mathrm{Cr}$ & 5 & 7 & 2 & $\mathrm{Cr}$ & 12 & 14 & 3 \\
\hline $\mathrm{TiO}_{2}$ & 6 & 8 & 1 & $\mathrm{Ba}$ & 11 & 14 & 4 \\
\hline $\mathrm{Zr}$ & 6 & 8 & - & $\mathrm{Tm}$ & 15 & 12 & 2 \\
\hline $\mathrm{Ba}$ & 6 & 8 & - & Sc & 7 & 11 & 11 \\
\hline $\mathrm{P}_{2} \mathrm{O}_{5}$ & 2 & 5 & 7 & $\mathrm{P}_{2} \mathrm{O}_{5}$ & 9 & 13 & 7 \\
\hline $\mathrm{Na}_{2} \mathrm{O}$ & 5 & 8 & 1 & $\mathrm{Zr}$ & 6 & 13 & 10 \\
\hline $\mathrm{FeO}^{*}$ & 5 & 9 & - & $\mathrm{Sr}$ & 9 & 18 & 2 \\
\hline $\mathrm{CaO}$ & 4 & 10 & - & $\mathrm{FeO}^{*}$ & 10 & 19 & - \\
\hline $\mathrm{Sr}$ & 3 & 11 & - & Co & 5 & 15 & 9 \\
\hline Co & 2 & 12 & - & $\mathrm{CaO}$ & 8 & 20 & 1 \\
\hline
\end{tabular}

The resulting rocks provide an inverted view of pre-eruption compositional gradients within source magma reservoirs.

Hildreth (1979) pioneered the use of enrichment-depletion diagrams in the evaluation of compositional variation within ash-flow tuffs. The composition of the earliest erupted magma is normalized to that of the latest erupted magma, and the resulting values, which identify the magnitude and direction of pre-eruption vertical compositional gradients within the reservoir, are graphically portrayed to create an image of compositional variation within the magma reservoir. Geochemical data for samples from compositional profiles of tuffs of the Narrows area were processed accordingly. In most cases, the composition of the sample from the lowest stratigraphic position (representing the earliest erupted, top of the magma reservoir) in the compositional profile of each unit was divided by that of the highest (latest erupted, relatively lower part of the magma reservoir). Vertical enrichment-depletion factors for 14 of 


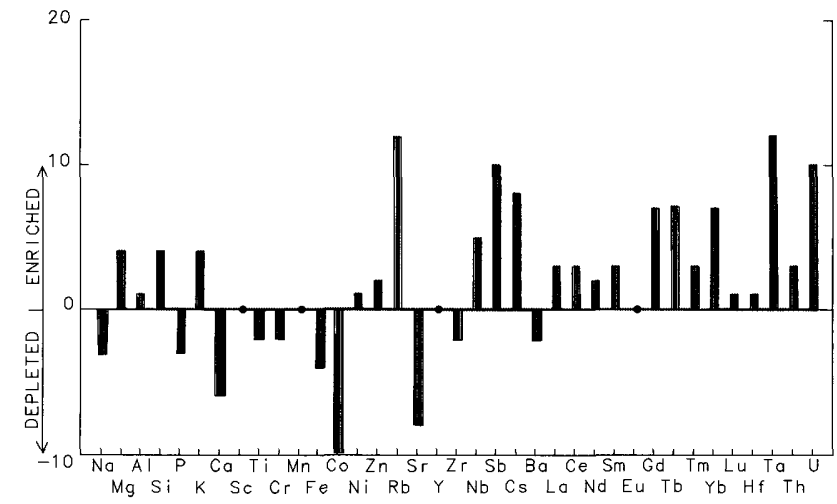

Figure 18. Histogram showing enrichment-depletion abundance behavior of oxides and elements in samples from composition profiles of the ash-flow tuffs in the White River Narrows area, Nevada. The height of each bar represents the number of instances (maximum of 14 possible; 1 per stratigraphic unit) in which the indicated oxide or element is enriched (early/late $>1$ ) minus the number of instances in which the indicated oxide or element is depleted (early/late $<1$ ), as compiled from figure 17 and table 6. Dots on zero baseline indicate oxides or elements that are enriched and depleted in the same number of units.

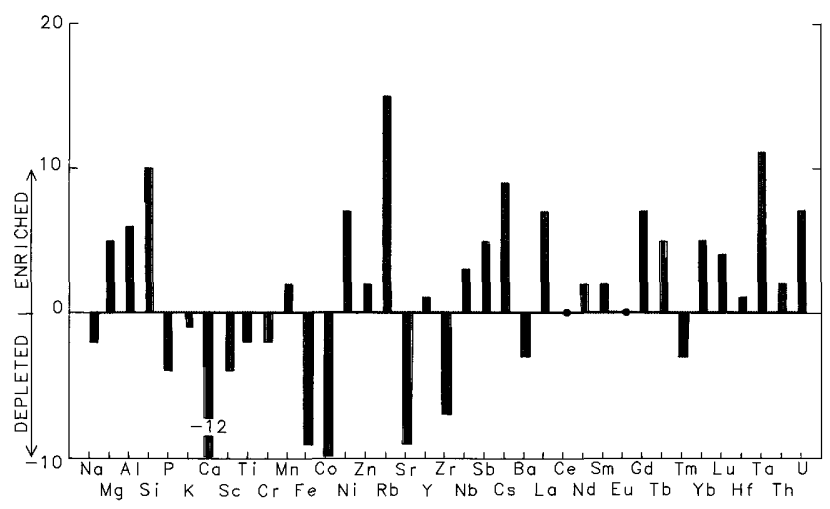

Figure 19. Histogram showing within-unit enrichment-depletion abundance behavior of oxides and elements in composition profile sample suites of ash-flow tuffs in the White River Narrows area, Nevada. The height of each bar represents the number of samples (maximum of 29 possible) in which the abundance of the indicated oxide or element is enriched relative to that in the immediately higher (stratigraphically), within-unit sample minus the number of samples in which the abundance of the indicated oxide or element is depleted relative to that of the immediately higher, within-unit sample. Dots on the zero baseline indicate elements that are enriched and depleted in the same number of samples.

the Narrows area tuffs were obtained (fig. 17). In three cases (discussed following), compositional variation for a number of major oxide or trace elements in the stratigraphically highest sample reverses enrichment-depletion trends depicted by other samples from the compositional profile of that unit. These samples were excluded from enrichmentdepletion factor computation.
Hildreth (1979) demonstrated that a number of oxides and elements, including $\mathrm{Na}_{2} \mathrm{O}, \mathrm{MnO}, \mathrm{Rb}, \mathrm{Y}, \mathrm{Nb}, \mathrm{Cs}$, heavy rare earth elements, $\mathrm{Ta}$, Th, and $\mathrm{U}$, were concentrated in the top of the magma reservoir represented by the Bishop Tuff, whereas a number of others, including $\mathrm{CaO}, \mathrm{TiO}_{2}, \mathrm{FeO}^{*}$, cobalt, strontium, zirconium, barium, and light rare earth elements were depleted in the top of the magma reservoir. Similar zonation patterns have been defined for many high-silica systems. Eruption of progressively deeper levels from magma reservoirs zoned in this fashion results in a "normally zoned" ash-flow tuff. Most of tuffs of the Narrows area are normally zoned; the Monotony Tuff is reversely zoned for many elements. Zonation patterns defined for a number of oxides and elements in tuffs of the Narrows area are, however, either inconsistent between the various stratigraphic units that they represent or opposite in direction to those for the Bishop and other similar high-silica tuffs. In addition, it is particularly noteworthy that the magnitudes of enrichments and depletions computed for various oxides and elements in tuffs of the Narrows area are significantly smaller than those for high-silica systems such as the Bishop Tuff (Hildreth, 1979). Zonation data for tuffs of the Narrows area can be summarized in several ways.

The number of tuffs of the Narrows area for which the abundances of each oxide or element is upward enriched, depleted, or unchanged (within analytical uncertainty) was compiled (table 6) from enrichment-depletion diagrams (fig. 17) in order to evaluate the consistency of between-unit oxide or element behavior. The difference between the number of enrichments and depletions, for each oxide or element in tuffs of the Narrows area, was computed and plotted (fig. 18) as a histogram in the form of an enrichment-depletion diagram. Accordingly, oxides and elements whose compositions are most systematically upward enriched or depleted can be identified. Surprisingly, very few oxides or elements are consistently either upward enriched or depleted in tuffs of the Narrows area. Specifically, only Rb, Ta, Sb, U, Cs, Tb, $\mathrm{Gd}$, and $\mathrm{Yb}$ are systematically (in two-thirds or more of all instances) upward enriched, and only $\mathrm{Co}, \mathrm{Sr}, \mathrm{CaO}$, and $\mathrm{FeO}^{*}$ are systematically upward depleted (downward enriched).

The consistency of within-unit behavior for each oxide or element was evaluated in a similar manner. Of the 44 samples collected in the compositional profiles, 29 pairs of these represent upsection, within-unit transitions. Whether the abundance of each oxide or element increases, decreases, or is unchanged (within analytical uncertainty) was compiled (from table 1) for each of these upsection within-unit sample pairs. The difference between the number of enrichments and depletions for each oxide or element in each of these 29 transitions was computed (table 6) and plotted (fig. 19) as a histogram in the form of an enrichment-depletion diagram that indicates the degree to which abundance variations of particular oxides and elements are monotonic. Within-unit oxide or element abundance variation is surprisingly nonmonotonic. Specifically, only the abundances of $\mathrm{SiO}_{2}$, 
rubidium, tantalum, and cesium display systematic (in twothirds or more of all instances) within-unit, upsection increases, and only the abundances of calcium, cobalt, $\mathrm{FeO}^{*}$, and strontium display similarly systematic within-unit, upsection decreases.

The representative nature of compositional data for samples from the compositional profiles is verified by comparing abundance ranges defined by compositional profile sample suites with those portrayed by samples collected without regard to vertical position. Specifically, abundance ranges for most of the oxides and elements in samples from compositional profiles of most of the stratigraphic units generally encompass (within analytical uncertainty) the abundance range defined by samples collected without regard to vertical position (fig. 16). Exceptions to this generalization probably reflect complex dynamics prevailing during eruption and emplacement. In some cases, as portrayed, for instance, by data for samples of the tuff of the Golden Gate Range (fig. 16), samples collected without regard to vertical position depict compositions that are missing from corresponding composition profile abundance ranges. These "missing" compositions, representing tuff aliquots derived from the highest and (or) lowest erupted parts of a zoned reservoir, may indicate nonpreservation, due to topographic relief or postdepositional scouring, in sections represented by corresponding composition profiles. In addition, the distal nature of these outflow deposits enhances the probability that some eruptive pulses, potentially representing any level within a zoned reservoir, may not have travelled to and been deposited in the Narrows area.

\section{DISCUSSION}

\section{CORRELATION}

Compositional ranges of major oxides and trace elements in samples of tuffs of the Narrows area (fig. 16) can be used to help determine the stratigraphic identity of a unit if field, petrographic, paleomagnetic, and geochronologic data either are unavailable or are insufficient. By comparing compositional data for a sample of tuff whose stratigraphic identity is uncertain with documented compositional ranges (fig. 16), it may be possible to identify the unknown tuff. This approach would be especially useful where limited exposure or structural dismemberment results in limited stratigraphic context. Various combinations or subsets of major oxides and trace elements, combined with field, petrographic, paleomagnetic, or geochronologic data, may facilitate stratigraphic correlation (Hildreth and Mahood, 1985).

In parts of the Seaman Range, contacts were mapped between distinct ash-flow tuffs whose stratigraphic identity could not be conclusively established on the basis of field observations. In addition, many problems developed during attempts by early workers to identify some of the ash-flow tuffs in the southeastern Great Basin. For instance, although Best, Christiansen, and others (1989), Best and others (1993), and Scott and others (in press) have summarized the petrographic, geochronologic, and paleomagnetic characteristics of the Cottonwood Wash Tuff, Wah Wah Springs Formation, Lund Formation, and Monotony Tuff, these units are frequently mistaken for one another. These factors led to development of the diagnostic compositional attributes for correlation described following.

Compositional data for a sample from limited outcrops of the Wah Wah Springs Formation in the Narrows area provide an inadequate base for stratigraphic correlation using geochemical criteria. Elevated $\mathrm{MgO}$, cobalt, nickel, chromium, zinc, and scandium abundances in this sample relative to all other tuffs in the Narrows area (fig. 16, table 5) suggest that composition data may be definitive in identification of this unit.

In the Narrows area, in particular, it has been difficult to distinguish the Lund from the Monotony in outcrops that lack stratigraphic context. Best and Grant (1987) indicated that the presence of accessory sphene is diagnostic of the Lund, but this criterion is not always reliable because sphene breaks down readily during vapor phase recrystallization; thus, although present as a magmatic phase, it may be absent in recrystallized tuff. Trace-element abundances (table 5) indicate, however, that the Lund and Monotony are compositionally distinct. In particular, the Lund has barium abundances distinctly lower than those of the Monotony. Most. but not all, "lower" barium samples also contain sphene.

M.G. Best (written commun., 1989) suggested that clinopyroxene is diagnostic of the Monotony. This observation was confirmed; no pyroxene was identified during petrographic analysis of 10 samples of compositional Lund rock from the Narrows area, whereas all 6 samples of compositional Monotony rock contained clinopyroxene. Although the presence of clinopyroxene seems to be diagnostic of Monotony, the extremely fine grain size and sparse abundance of this mineral cause this criterion to be of limited utility. Tentative identification of the Lund or Monotony can be achieved using the presence of sphene or clinopyroxene, and more certain distinctions can be made using relative abundances of barium, $\mathrm{TiO}_{2}, \mathrm{P}_{2} \mathrm{O}_{5}$, and thorium (definitive) and $\mathrm{SiO}_{2}, \mathrm{FeO}^{*}$, tantalum, and many of the rare earth elements (less definitive) in samples of these two units.

The Petroglyph Cliff Ignimbrite shares a number of compositional similarities with the Isom-compositional type tuffs (Best, Christiansen, and others, 1989). In particular, it is characterized by a low $\mathrm{SiO}_{2}$ content and high abundances of $\mathrm{FeO}^{*}, \mathrm{TiO}_{2}, \mathrm{P}_{2} \mathrm{O}_{5}$, zirconium, scandium, europium, and the heavy rare earth elements relative to most other tuffs of the Narrows area.

Compositional data for tuffs in the interval between the Monotony and the Leach Canyon Formation in the Narrows area provide a clear example of the utility of compositional data, and of trace elements in particular, in stratigraphic 



$A$

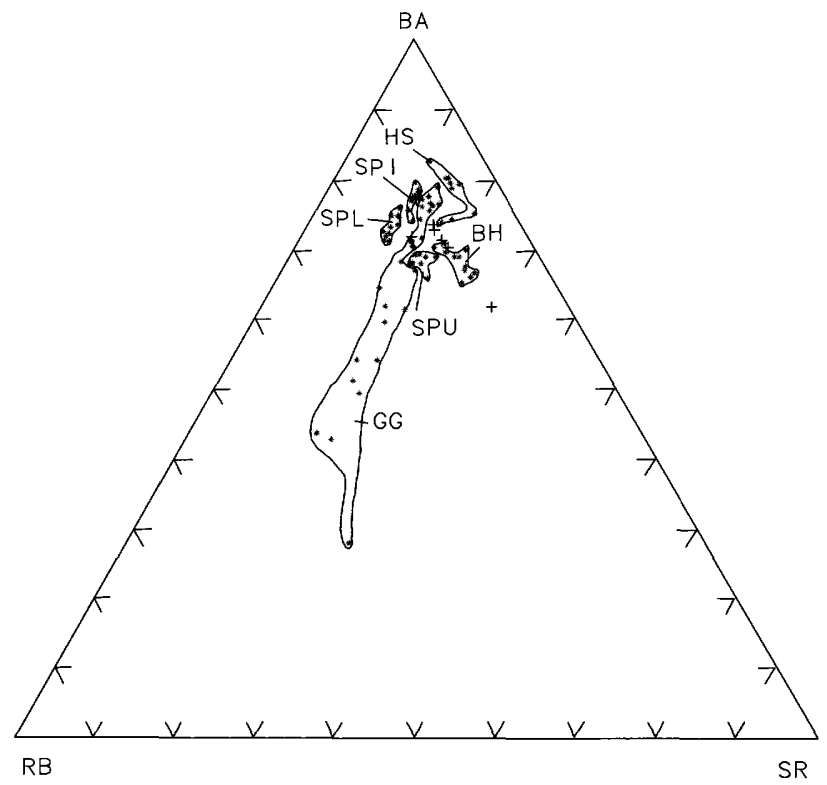

$B$

Figure 20. Variation diagrams showing compositions of samples of in the stratigraphic interval between (and including) the Baldhills and Hole-in-the Wall Members of the Isom Formation, White River Narrows area, Nevada. BH, Baldhills Member of the Isom Formation; SPL and SPI, lower and intermediate cooling units, respectively, of the Shingle Pass Tuff; GG, tuff of the Golden Gate Range; HS, tuff of Hancock Summit; SPU, upper cooling unit of the Shingle Pass Tuff; HW, Hole-in-the-Wall Member of the Isom Formation. A, Strontium-zirconiumrubidium. Data for the upper cooling unit of the Shingle Pass Tuff shown by pluses. $B$, Rubidium-barium-strontium. Data for the Hole-inthe-Wall Member of the Isom Formation shown by pluses. $C$, Barium versus strontium. Data for the Hole-in-the Wall Member of the Isom Formation shown by pluses.

correlation. At the onset of geologic mapping in the Seaman Range (du Bray and Hurtubise, 1994), ash-flow tuff stratigraphy in the interval between the Monotony Tuff and the Leach Canyon Formation was poorly known. Field observations indicated that a number of grossly similar tuffs were present within this interval but that their distribution was not continuous throughout the Seaman Range. Trace-element data for samples collected without regard to vertical position within this interval suggested the presence of seven compositionally distinct stratigraphic units (fig. 20). Subsequent 
work demonstrated that the abundances of rubidium, strontium, zirconium, and barium in each of these units define distinct, generally nonoverlapping compositional fields (fig. 20 ). Units whose compositional fields overlap on one diagram, such as those of the tuff of the Golden Gate Range and the upper cooling unit of the Shingle Pass Tuff on the ternary strontium-zirconium-rubidium diagram (fig. 20A), form distinct fields on a barium versus strontium plot (fig. 20C). Noting relative stratigraphic and geographic positions of samples that composed the various compositional groups enabled development of a composite stratigraphic column containing these seven ash-flow tuffs. Ultimately, an intact section, $1.5 \mathrm{~km}$ north of Fossil Peak (fig. 1), containing all of these tuffs, in stratigraphic contact, was identified and sampled in detail to verify the inferred relative stratigraphic and compositional relations.

Compositional data for the Leach Canyon Formation provide another example of the utility of trace-element data in stratigraphic correlation. Multiple ash flows were observed within the Leach Canyon Formation; analytical data for samples from throughout this unit enable identification of a major compositional, stratigraphic break within this sequence of ash flows. The composition break is coincident with the prominent horizontal parting noted by Williams (1967) within the Narrows Tuff Member of the Leach Canyon Formation in the Narrows area (fig. 1). Ash-flow tuff in the lower part of the Leach Canyon Formation is characterized by elevated abundances of $\mathrm{SiO}_{2}, \mathrm{Ta}$, Th, and $\mathrm{U}$ and by depleted abundances of $\mathrm{FeO}^{*}, \mathrm{P}_{2} \mathrm{O}_{5}, \mathrm{Sr}, \mathrm{Ba}, \mathrm{Zn}, \mathrm{Sc}$, and the light rare earth elements relative to their abundances in tuff from the upper part of the Leach Canyon Formation and other tuffs of the Narrows area (fig. 16). Abundances of individual trace elements in samples of the upper ash-flow tuff of the Leach Canyon Formation are not diagnostic although combinations of trace-element features, such as low zirconium, scandium, and rare earth element abundances and elevated $\mathrm{Na}_{2} \mathrm{O}$, cobalt, and tantalum abundances, enable discrimination of this unit from other tuffs of the Narrows area.

The composition of the Swett Tuff Member of the Condor Canyon Formation is distinguished by abundances similar to those of the Isom-compositional-type tuffs of Best, Christiansen, and others (1989). Specifically, samples of the Swett Tuff Member are characterized by elevated abundances of $\mathrm{K}_{2} \mathrm{O}, \mathrm{Zr}, \mathrm{Hf}, \mathrm{La}, \mathrm{Ce}, \mathrm{Tb}, \mathrm{Yb}$, and $\mathrm{Lu}$. These compositional features, as well as previously described distinctive field appearance, thinness, and petrographic characteristics, clearly distinguish the Swett Tuff Member from other tuffs of the Narrows area.

One of the most diagnostic features of the Bauers Tuff Member of the Condor Canyon Formation is its relative compositional homogeneity. In addition, samples of the Bauers Tuff Member are characterized by elevated abundances of $\mathrm{Na}_{2} \mathrm{O}, \mathrm{K}_{2} \mathrm{O}$, zirconium, and hafnium and among the highest abundances of thorium and uranium of any of tuffs of the Narrows area.
The Pahranagat Formation is one of the most silica rich tuffs of the Narrows area. Another diagnostic feature of the Pahranagat is its relatively weakly developed incompatible trace-element enrichment for such a high-silica rhyolite. It is further distinguished by low abundances of $\mathrm{FeO}^{*}$, strontium, zirconium, barium, scandium, and light rare earth elements. These compositional characteristics and abundant unflattened pumice blocks are diagnostic of this unit.

The Harmony Hills Tuff is the most mafic of the Narrows area tuffs. Its composition is characterized by low $\mathrm{SiO}_{2}$ abundances and by high abundances of $\mathrm{FeO}^{*}, \mathrm{MgO}$, $\mathrm{CaO}, \mathrm{TiO}_{2}, \mathrm{P}_{2} \mathrm{O}_{5}$, strontium and particularly high abundances of cobalt, nickel, chromium, and scandium relative to the other tuffs of the Narrows area. Relatively coarse, abundant biotite also distinguishes this unit from other tuffs of the Narrows area.

The composition of the Hiko Tuff is perhaps the most nondistinct of any tuff exposed in the Narrows area. Abundances of most oxides and elements in samples of this unit overlap those of many other tuffs of the Narrows area. The Hiko Tuff is characterized by slightly low abundances of yttrium relative to most of tuffs of the Narrows area and by high abundances of cobalt relative to all of tuffs of the Narrows area younger than the Monotony Tuff. Fortunately, its stratigraphic position above the distinctive Harmony Hills Tuff and the fact that it weathers to prominent low cliffs covered by a distinctive moderate-reddish-brown patina render it somewhat distinctive.

\section{ZONATION}

Most of tuffs of the Narrows area display compositional zoning that is generally similar to that described for the Bishop Tuff (Hildreth, 1979); however, compositional zonation within the tuffs of the Narrows area is less systematic than that of some high-silica rhyolites and the magnitude of enrichments and depletions is smaller (fig. 18). Specifically, the most systematically zoned of the tuffs of the Narrows area-that is, tuffs whose compositions most nearly display monotonic variation in their composition profiles-are the Petroglyph Cliff Ignimbrite, the Swett Tuff Member of the Condor Canyon Formation, and the upper part of the Leach Canyon Formation (fig. 16). The tuff of the Golden Gate Range, the Petroglyph Cliff Ignimbrite, the Swett Tuff Member, and the Pahranagat Formation are among the most strongly zoned of tuffs of the Narrows area (fig. 17), whereas the Harmony Hills Tuff, the Bauers Tuff Member of the Condor Canyon Formation, the upper part of the Leach Canyon Formation, and lower and upper cooling units of the Shingle Pass Tuff are the most weakly zoned.

Relative to the Bishop Tuff, the Monotony Tuff is reversely zoned in many elements. Abundances of $\mathrm{SiO}_{2}$, $\mathrm{K}_{2} \mathrm{O}$, rubidium, barium, thorium, uranium, and light rare earth elements are enriched in samples (inferred to represent 
deep reservoir levels) from the top of the Monotony composition profile, whereas abundances of $\mathrm{FeO} * \mathrm{MgO}, \mathrm{CaO}$, $\mathrm{TiO}_{2}$, strontium, and scandium are enriched in samples (inferred to represent shallow reservoir levels) from the base of the profile (table 2, fig. 16).

One explanation for the reversed zoning is that the Monotony Tuff source reservoir was normally zoned and was evacuated from bottom to top. This scenario is unlikely, however, because it would require very high initial eruption rates (Blake and Ivey, 1986a, b), followed by progressively decreasing eruption rates. This eruption style requires that magma in the upper part of the reservoir be effectively shouldered aside and blocked from entering eruption conduits by magma surging upward, from deep in the reservoir, in response to very high eruption rates; this process requires a large vent and an enhanced eruption driving force.

A second possibility is that the contents of the Monotony Tuff reservoir became reversely zoned by magmatic processes. Zonation of this type, however, has not been demonstrated for other systems, and the mechanisms by which this type of zonation would develop are unknown.

Another process by which the Monotony Tuff might have become reversely zoned is that outlined by Duffield and Ruiz (1992) for the reversely zoned part of the Oligocene Taylor Creek Rhyolite reservoir. They suggested that magmatic processes within the reservoir favored normal zonation but that these processes were overwhelmed, specifically at the top of the reservoir, by assimilation of relatively geochemically primitive roof rock that caused compositional zonation reversal. Similarly, assimilation of relatively unevolved roof rocks at the top of the Monotony reservoir may have overwhelmed evolution of a normal composition profile. If so, progressively more evolved compositions from deeper in the chamber (stratigraphically higher samples) would indicate decreasing contamination by assimilation of geochemically primitive roof rock.

The composition of sample 201723 from the top of the Monotony profile (inferred to represent the deepest sampled level in the source reservoir) depicts a zonation reversal toward normal zonation and more primitive compositions. This observation suggests the presence of a threshold in the Monotony reservoir, in the part of the reservoir represented by samples 201723 and 201722, in which magmatic processes that lead to normal zonation became dominant over the roof-rock assimilation or contamination process.

Compositions of the uppermost samples of the Lund and Pahranagat Formations reverse the variation patterns portrayed by the remaining samples in these profiles (fig. 16). In each unit, uppermost samples depict more evolved compositions than the samples collected immediately below. Thus, these samples represent a discontinuity in the pattern of eruption of progressively less evolved magma from progressively deeper reservoir levels. These compositional relations may depict diminished eruption rates during the waning stages of reservoir evacuation. As a consequence, more evolved, residual magma, shouldered aside and blocked from eruption conduits during the time of high eruption rates, was able to reestablish contact with eruption conduits. Pertinent studies concerning the effects of variable eruption dynamics have been discussed by Blake and Ivey (1986a, b), and similar compositional reversals, described by Boden (1989), characterize ash-flow tuff erupted from the Toquima caldera complex of Nevada.

\section{CONCLUDING REMARKS}

Trace-element data enabled conclusive identification and correlation of middle Tertiary ash-flow tuffs in the Narrows area of the southeastern Great Basin. Whole-rock analysis by energy-dispersive $\mathrm{X}$-ray fluorescence is fast and relatively inexpensive; thus, use of this type of data should become a more routine part of ash-flow tuff characterization and correlation.

Hildreth $(1979$, p. 71$)$ urged that "Elemental distribution patterns within several well-preserved ash-flow complexes that cover a range of volumes, compositions $* * *$ need to be established." Middle Tertiary ash-flow tuffs of the southeastern Great Basin, especially those of the Narrows area, meet these criteria well. Some speculation concerning the differences between vertical compositional zonation in high-silica ash-flow tuffs, as epitomized by the Bishop Tuff, and tuffs of the Narrows area follows.

The bulk composition of magma erupted during caldera-forming events is certainly a function of conditions prevailing in the source region during magma genesis and is also a function of pre-eruption reservoir processes. Highly evolved high-silica magmas, which are characterized by extreme geochemical gradients, may require significantly more time to evolve in crustal reservoirs than less evolved, less strongly zoned systems. The diversity of vertical zonation portrayed by tuffs of the Narrows area may, in part, reflect pre-eruption reservoir residence times.

Perhaps the most characteristic feature of high-silica tuffs is their extremely evolved geochemical character. The compositions of these tuffs depict maximum degrees of geochemical evolution including remarkable enrichments in $\mathrm{Rb}, \mathrm{Nb}, \mathrm{Y}, \mathrm{Sb}, \mathrm{Cs}, \mathrm{Ta}, \mathrm{U}$, and heavy rare earth element abundances and depletions in $\mathrm{FeO}^{*}, \mathrm{Ba}, \mathrm{Sr}$, and $\mathrm{Eu}$ abundances. None of tuffs of the Narrows area is characterized by geochemical features of this type; herein may lie a source of the differences in the consistency and magnitude of enrichments and depletions in oxide-element abundances for tuffs of the Narrows area.

The similar sense and magnitude of enrichment and depletion in high-silica systems for most reservoirs (Hildreth, 1979) suggest that similar geochemical processes are acting with similar efficiencies in these systems. Processes such as double-diffusive fractional crystallization (Christiansen, 1983) that result in extreme compositional gradients 
in high-silica reservoirs may operate weakly, if at all, in less evolved reservoirs. Variability of the sense and magnitude of enrichments and depletions portrayed by tuffs of the Narrows area suggests that no single process can be responsible for evolution of these geochemical features. Because reservoirs represented by tuffs of the Narrows area were not similarly zoned, other processes, in particular crystal fractionation, were more likely responsible for geochemical gradients preserved in composition profiles of tuffs of the Narrows area.

Tuffs of the Narrows area span a wide composition range, from low-silica dacite to high-silica rhyolite. Consequently, geochemical processes and efficiencies controlling the development of vertical zonation in their source reservoirs may have been highly variable. In particular, if crystalliquid equilibrium and crystal fractionation played major roles in compositional evolution, the fact that magma bulk compositions, as indicated by the diversity of average compositions of ash-flow tuffs of the Narrows area, were different among the stratigraphic units mandates distinct fractionating mineral assemblages for each of the source reservoirs. Variable fractionating assemblages, each having distinctive bulk distribution coefficients, may have caused the sense and magnitude of oxide or element enrichments and depletions defined by tuffs of the Narrows area to be highly variable. Rigorous petrogenetic modelling is beyond the scope of this study, but data presented herein pertaining to compositions of the tuffs of the Narrows area and to the type and relative proportions of phenocrysts contained therein should prove useful in future studies of compositional evolution within individual middle Tertiary magma reservoirs of the southeastern Great Basin.

The temporal-compositional variation among Narrows area tuffs, known to have been derived from several sources, may provide some insight, though highly speculative, into the crust-mantle magmatic processes responsible for voluminous middle Tertiary magmatism in the southeastern Great Basin. In particular, with regard to Cenozoic magmatism in the southeastern Great Basin, it is noteworthy that Johnson (1991) considered that all Cenozoic silicic ash-flow magma in western North America results from fractional crystallization of mantle-derived magmas that assimilated varying amounts of continental crust.

One of the initial, voluminous pulses of middle Tertiary magmatism in the southeastern Great Basin, represented by the eruption of voluminous dacitic ash flows from the Indian Peak caldera complex, may reflect input of mantle-derived basaltic magma at the base of the crust and its evolution by fractional crystallization and assimilation to dacitic compositions. This influx of basaltic magma at the base of the crust probably caused anatexis throughout the region and generation of relatively low density liquids whose presence created a gravitational boundary to further upward migration of more dense basaltic magma. The resulting anatectic magmas may be represented, as a consequence of similar processes acting throughout a large region, by ash-flow tuffs erupted from the Central Nevada and Caliente caldera complexes. The compositions of these ash-flow tuffs are dramatically more evolved (fig. 16) than those of the Indian Peak caldera complex, perhaps because they represent eruption of magma generated by partial melting at the base of the crust and therefore include smaller mantle components than more nearly primary magmas erupted from the Indian Peak caldera complex. This hypothesis could be tested using radiogenic isotopic data.

The eruption of progressively less evolved magmas from the Central Nevada and Caliente caldera complexes (fig. 16) may reflect the emptying (by eruption) and solidification of the anatectic reservoirs. Residual magma in these reservoirs may have involved progressively larger mantle components as the low-density barrier above basalt ponded at the base of the crust was eliminated; subsequently erupted magma, which may have included progressively larger mantle contributions, was geochemically less evolved as a consequence. This process culminated, as ashflow eruptions diminshed during the early Miocene, with the renewed eruption, beginning about $17 \mathrm{Ma}$ (Best, Christiansen, and others, 1989), of mantle-derived basalt in the southeastern Great Basin.

\section{REFERENCES CITED}

Anders, Edward, and Ebihara, Mitsuru, 1982, Solar-system abundances of the elements: Geochimica et Cosmochimica Acta, v. 46, p. 2363-2380.

Anderson, J.J., and Rowley, P.D., 1975, Cenozoic stratigraphy of southwestern High Plateaus of Utah, in Anderson, J.J., Rowley, P.D., Fleck, R.J., and Nairn, A.E.M., eds., Cenozoic geology of southwestern High Plateaus of Utah: Geological Society of America Special Paper 160, p. 1-52.

Armstrong, R.L., 1970, Geochronology of Tertiary igneous rocks, eastern Basin and Range Province, western Utah, eastern Nevada, and vicinity, U.S.A.: Geochimica et Cosmochimica Acta, v. 34, p. 203-232.

Baedecker, P.A., and McKown, D.M., 1987, Instrumental neutron activation analysis of geochemical samples, in Baedecker, P.A., ed., Methods for geochemical analysis: U.S. Geological Survey Bulletin 1770, p. H1-H14.

Best, M.G., and Christiansen, E.H., 1991, Limited extension during peak Tertiary volcanism, Great Basin of Nevada and Utah: Journal of Geophysical Research, v. 96, p. 13,509-13,528.

Best, M.G., Christiansen, E.H., and Blank, H.R., Jr., 1989, Oligocene caldera complex and calc-alkaline tuffs and lavas of the Indian Peak volcanic field, Nevada and Utah: Geological Society of America Bulletin, v. 101, p. 1076-1090.

Best, M.G., Christiansen, E.H., Deino, A.L., Grommé, C.S., McKee, E.H., and Noble, D.C., 1989, Excursion 3A-Eocene through Miocene volcanism in the Great Basin of the western United States, in Chapin, C.E., and Zidek, J., eds., Field excursions to volcanic terranes in the Western United States, volume 
II-Cascades and Intermountain West: New Mexico Bureau of Mines and Mineral Resources Memoir 47, p. 91-133.

Best, M.G., and Grant, S.K., 1987, Stratigraphy of the volcanic Oligocene Needles Range Group in southwestern Utah and eastern Nevada: U.S. Geological Survey Professional Paper 1433-A, 28 p.

Best, M.G., Scott, R.B., Rowley, P.D., Swadley, W.C., Anderson, R.E., Gromme, C.S., Harding, A.E., Deino, A.L., Christiansen, E.H., Tingey, D.G., and Sullivan, K.R., 1993, OligoceneMiocene caldera complexes, ash-flow sheets, and tectonism in the central and southeastern Great Basin, in Lahren, M.M., Trexler, J.H., Jr., and Spinosa, C., eds., Crustal evolution of the Great Basin and Sierra Nevada: Cordilleran-Rocky Mountain Section, Geological Society of America Guidebook, Department of Geological Sciences, University of Nevada, Reno, p. 285-311.

Blake, S., and Ivey, G.N., 1986a, Magma-mixing and the dynamics of withdrawal from stratified reservoirs: Journal of Volcanology and Geothermal Research, v. 27, p. 153-178.

1986b, Density and viscosity gradients in zoned magma chambers, and their influence on withdrawal mechanics: Journal of Volcanology and Geothermal Research, v. 30, p. 201-230.

Blank, H.R., Jr., 1959, Geology of the Bull Valley district, Washington County, Utah: Seattle, University of Washington, Ph.D. thesis, $177 \mathrm{p}$.

Boden, D.R., 1989, Evidence for step-function zoning of magma and eruptive dynamics, Toquima caldera complex, Nevada: Journal of Volcanology and Geothermal Research, v. 37, p. 39-57.

Christiansen, E.H., 1983, The Bishop Tuff revisited-Compositional zonation by double-diffusive fractional crystallization (DDFC): Geological Society of America Abstracts with Programs, v. 15 , p. 390.

Christiansen, R.L., and Lipman, P.W., 1972, Cenozoic volcanism and plate-tectonic evolution of the western United States, II, Late Cenozoic: Royal Society of London, Philosophical Transactions (A), v. 271, p. 249-284.

Cook, E.F., 1965, Stratigraphy of Tertiary volcanic rocks in eastern Nevada: Nevada Bureau of Mines Report 11, 61 p.

Deino, A.L., and Best, M.G., 1988, Use of high-precision single crystals ${ }^{40} \mathrm{Ar} /{ }^{39} \mathrm{Ar}$ ages and TRM data in correlation of an ashflow deposit in the Great Basin: Geological Society of America Abstracts with Programs, v. 20, no. 7, p. A397.

Dolgoff, A., 1963, Volcanic stratigraphy of the Pahranagat area, Lincoln County, southeastern Nevada: Geological Society of America Bulletin, v. 74, p. 875-900.

du Bray, E.A., and Hurtubise, D.O., 1994, Geologic map of the Seaman Range, Lincoln and Nye Counties, Nevada: U.S. Geological Survey Miscellaneous Investigations Map I-2282, scale $1: 50,000$.

Duffield, W.A., and du Bray, E.A., 1990, Temperature size and depth of the magma reservoir for the Taylor Creek Rhyolite, New Mexico: American Mineralogist, v. 75, p. 1059-1070.

Duffield, W.A., and Ruiz, J., 1992, Compositional gradients in large reservoirs of silicic magma as evidenced by ignimbrites versus Taylor Creek Rhyolite lava domes: Contributions to Mineralogy and Petrology, v. 110, p. 192-210.

Ekren, E.B., Anderson, R.E., Rogers, C.L., and Noble, D.C., 1971, Geology of northern Nellis Air Force Base bombing and gunnery range, Nye County, Nevada: U.S. Geological Survey Professional Paper 651, $91 \mathrm{p}$.
Ekren, E.B., Orkild, P.P., Sargent, K.A., and Dixon, G.L., 1977, Geologic map of Tertiary rocks, Lincoln County, Nevada: U.S. Geological Survey Miscellaneous Investigations Series Map I-1041, scale 1:250,000.

Elsass, F., and du Bray, E.A., 1982, Energy-dispersive X-ray fluorescence spectrometry with the Kevex 7000 system: Saudi Arabian Deputy Ministry Mineral Resources Open File Report USGS-OF-02-52, $53 \mathrm{p}$.

Ewart, A., 1982, The mineralogy and petrology of Tertiary-Recent orogenic volcanic rocks, in Thorpe, R.S., ed., Andesites: Chichester, Wiley, p. 25-87.

Feeley, T.C., and Grunder, A.C., 1991, Hybridization of crust and mantle melts during early phases of extension-The Egan Range volcanic complex, eastern Nevada: Contributions to Mineralogy and Petrology, v. 106, p. 154-169.

Fridrich, C.J., and Mahood, G.A., 1987, Compositional layers in the zoned magma chamber of the Grizzly Peak tuff: Geology, v. 15, p. 299-303.

Gans, P.B., Mahood, G.A., and Schermer, E., 1989, Synextensional magmatism in the Basin and Range Province-A case study from the eastern Great Basin: Geological Society of America Special Paper 233, 58 p.

Gill, James, 1981, Orogenic andesites and plate tectonics: New York, Springer-Verlag, 390 p.

Gromme, C.S., McKee, E.H., and Blake, M.C., Jr., 1972, Paleomagnetic correlations and potassium-argon dating of middle Tertiary ash-flow sheets in the eastern Great Basin, Nevada and Utah: Geological Society of America Bulletin, v. 83, p. 1619-1638.

Hanson, G.N., 1978, The application of trace elements to the petrogenesis of igneous rocks of granitic composition: Earth and Planetary Science Letters, v. 38, p. 26-43.

Hildreth, Wes, 1979, The Bishop Tuff-Evidence for the origin of compositional zonation in silicic magma chambers, in Chapin, C.E., and Elston, W.E., eds., Ash-flow tuffs: Geological Society of America Special Paper 180, p. 43-75.

1981, Gradients in silicic magma chambers-Implications for lithospheric magmatism: Journal of Geophysical Research, ser. B, v. 86, p. 10153-10192.

Hildreth, Wes, and Mahood, Gail, 1985, Correlation of ash-flow tuffs: Geological Society of America Bulletin, v. 96, p. 968-974.

Hurtubise, D.O., and du Bray, E.A., 1992, Stratigraphy and structure of the Seaman Range and Fox Mountain, Lincoln and Nye Counties, Nevada: U.S. Geological Survey Bulletin 1988-B, 31 p.

Irvine, T.N., and Baragar, W.R.A., 1971, A guide to the chemical classification of the common volcanic rocks: Canadian Journal of Earth Sciences, v. 8, p. 523-548.

Johnson, C.M., 1991, Large-scale crust formation and lithosphere modification beneath middle to late Cenozoic calderas and volcanic fields, western North America: Journal of Geophysical Research, v. 96, p. 13485-13507.

Le Bas, M.J., Le Maitre, R.W., Streckeisen, A., and Zannetin, B., 1986, A chemical classification of volcanic rocks based on the total alkali-silica diagram: Journal of Petrology, v. 27, p. 745-750.

Lipman, P.W., 1965, Chemical comparison of glassy and crystalline volcanic rocks: U.S. Geological Survey Bulletin 1201-D, 24 p. 
1980, Cenozoic volcanism in the western United States-Implications for continental tectonics, in Burchfiel, B.C., Oliver, J.E., and Silver, L.T., eds., Continental tectonics: National Academy of Sciences, p. 161-174.

Lipman, P.W., Protska, H.J., and Christiansen, R.L., 1972, Cenozoic volcanism and plate-tectonic evolution of the western United States, I, early and middle Cenozoic: Royal Society of London, Philosophical Transactions (A), v. 271, p. 217-248.

Macdonald, R., Smith, R.L., and Thomas, J.E., 1992, Chemistry of the subalkalic silicic obsidians: U.S. Geological Survey Professional Paper 1523, $214 \mathrm{p}$.

Mackin, J.H., 1960, Structural significance of Tertiary volcanic rocks in southwestern Utah: American Journal of Science, v. 258, 81-131.

Pearce, J.A., Harris, N.B.W., and Tindle, A.G., 1984, Trace element discrimination diagrams for the tectonic interpretation of granitic rocks: Journal of Petrology, v. 25, p. 956-983.

Rowley, P.D., McKee, E.H., and Blank, H.R., Jr., 1989, Miocene gravity slides resulting from emplacement of the Iron Mountain pluton, southern Iron Springs mining district, Iron County, Utah: EOS (Transactions of the American Geophysical Union), v. 70, no. 43, p. 1309.

Rowley, P.D., Nealey, L.D., Unruh, D.M., Snee, L.W., Mehnert, H.M., Anderson, R.E., Gromme, C.S., and Siders, M.A., in press, Stratigraphy of Oligocene and Miocene ash-flow tuffs in and near the Caliente caldera complex, southeastern Nevada and southwestern Utah: U.S. Geological Survey Bulletin.

Rowley, P.D., and Siders, M.A., 1988, Miocene calderas of the Caliente caldera complex, Nevada-Utah: EOS (Transactions of the American Geophysical Union), v. 69, no. 44, p. 1508.

Rowley, P.D., Steven, T.A., Anderson, J.J., and Cunningham, C.G., 1979, Cenozoic stratigraphy and structural framework of southwestern Utah: U.S. Geological Survey Professional Paper $1149,22 \mathrm{p}$.

Sargent, K.A., and Houser, F.N., 1970, The Shingle Pass Tuff of central Nevada: Geological Society of America Abstracts with Programs, v. 2, no. 2, p. 140-141.

Sawyer, D.A., and Sargent, K.A., 1989, Petrologic evolution of divergent peralkaline magmas from the Silent Canyon caldera complex, southwestern Nevada volcanic field: Journal of Geophysical Research, v. 94, p. 6021-6040.

Scott, R.B., Gromme, C.S., Best, M.G., Rosenbaum, J.G., and Hudson, M.R., in press, Stratigraphic relationships of Tertiary volcanic rocks in central Lincoln County, southeastern Nevada: U.S. Geological Survey Bulletin.

Smith, R.L., 1979, Ash-flow magmatism: Geological Society of America Special Paper 180, p. 5-27.

Snyder, R.P., Ekren, E.B., and Dixon, G.L., 1972, Geologic map of the Lunar Crater quadrangle, Nye County, Nevada: U.S. Geological Survey Miscellaneous Investigations Series Map I-700, scale $1: 48,000$.

Taggart, J.E., Lindsay, J.R., Scott, B.A., Vivit, D.V., Bartel, A.J., and Stewart, K.C., 1987, Analysis of geologic materials by Xray fluorescence spectrometry, in Baedecker, P.A., ed., Methods for geochemical analysis: U.S. Geological Survey Bulletin 1770 , p. E1-E19.

Taylor, W.J., Bartley, J.M., Lux, D.R., and Axen, G.J., 1989, Timing of Tertiary extension in the Railroad Valley-Pioche transect, Nevada-Constraints from ${ }^{40} \mathrm{Ar} /{ }^{39} \mathrm{Ar}$ ages of volcanic rocks: Journal of Geophysical Research, v. 94, p. 7757-7774.

Thompson, R.N., Morrison, M.A., Dickin, A.P., Hendry, G.L., 1983, Continental flood basalts...Arachnids rule OK?, in Hawkesworth, C.J., and Norrey, M.J., eds., Continental flood basalts and xenoliths: Cheshire, England, Shiva Publishing, p. 158-185.

Ward, P.L., 1991, On plate tectonics and the geologic evolution of southwestern North America: Journal of Geophysical Research, v. 96, p. 12479-12496.

Watson, E.B., and Harrison, T.M., 1983, Zircon saturation revisited-Temperature and composition effects in a variety of crustal magma types: Earth and Planetary Science Letters, v. 64 , p. 295-304.

Williams, P.L., 1960, A stained slice method for rapid determination of the phenocryst composition of volcanic rocks: American Journal of Science, v. 258, p. 148-152.

1967 , Stratigraphy and petrography of the Quichapa Group, southwestern Utah and southeastern Nevada: Seattle, University of Washington, Ph.D. thesis, $139 \mathrm{p}$.

Wood, D.A., Joron, J.-L., and Treuil, M., 1979, A re-appraisal of the use of trace elements to classify and discriminate between magma series erupted in different tectonic settings: Earth and Planetary Sciences Newsletter, v. 45, p. 326-336.

Yager, D.B., and Quick, J.E., 1992, Superxap manual: U.S. Geological Survey Open-File Report 92-13, 45 p.
Published in the Central Region, Denver, Colorado

Manuscript approved for publication August 16, 1994

Edited by Judith Stoeser

Graphics prepared by Denny Welp, Alex Donatich, and the author

Photocomposition by Mari L. Kauffmann

Tables typeset by Judith Stoeser 


\section{SELECTED SERIES OF U.S. GEOLOGICAL SURVEY PUBLICATIONS}

\section{Periodicals}

Earthquakes \& Volcanoes (issued bimonthly).

Preliminary Determination of Epicenters (issued monthly).

\section{Technical Books and Reports}

Professional Papers are mainly comprehensive scientific reports of wide and lasting interest and importance to professional scientists and engineers. Included are reports on the results of resource studies and of topographic, hydrologic, and geologic investigations. They also include collections of related papers addressing different aspects of a single scientific topic.

Bulletins contain significant data and interpretations that are of lasting scientific interest but are generally more limited in scope or geographic coverage than Professional Papers. They include the results of resource studies and of geologic and topographic investigations; as well as collections of short papers related to a specific topic.

Water-Supply Papers are comprehensive reports that present significant interpretive results of hydrologic investigations of wide interest to professional geologists, hydrologists, and engineers. The series covers investigations in all phases of hydrology, including hydrology, availability of water, quality of water, and use of water.

Circulars present administrative information or important scientific information of wide popular interest in a format designed for distribution at no cost to the public. Information is usually of short-term interest.

Water-Resources Investigations Reports are papers of an interpretive nature made available to the public outside the formal USGS publications series. Copies are reproduced on request unlike formal USGS publications, and they are also available for public inspection at depositories indicated in USGS catalogs.

Open-File Reports include unpublished manuscript reports, maps, and other material that are made available for public consultation at depositories. They are a nonpermanent form of publication that may be cited in other publications as sources of information.

\section{Maps}

Geologic Quadrangle Maps are multicolor geologic maps on topographic bases in $71 / 2$ - or 15 -minute quadrangle formats (scales mainly $1: 24,000$ or $1: 62,500$ ) showing bedrock, surficial, or engineering geology. Maps generally include brief texts; some maps include structure and columnar sections only.

Geophysical Investigations Maps are on topographic or planimetric bases at various scales, they show results of surveys using geophysical techniques, such as gravity, magnetic, seismic, or radioactivity, which reflect subsurface structures that are of economic or geologic significance. Many maps include correlations with the geology.

Miscellaneous Investigations Series Maps are on planimetric or topographic bases of regular and irregular areas at various scales; they present a wide variety of format and subject matter. The series also includes 7 1/2-minute quadrangle photogeologic maps on planimetric bases which show geology as interpreted from aerial photographs. The series also includes maps of Mars and the Moon.
Coal Investigations Maps are geologic maps on topographic or planimetric bases at various scales showing bedrock or surficial geology, stratigraphy, and structural relations in certain coal-resource areas.

Oil and Gas Investigations Charts show stratigraphic information for certain oil and gas fields and other areas having petroleum potential.

Miscellaneous Field Studies Maps are multicolor or black-andwhite maps on topographic or planimetric bases on quadrangle or irregular areas at various scales. Pre-1971 maps show bedrock geology in relation to specific mining or mineral-deposit problems; post-1971 maps are primarily black-and-white maps on various subjects such as environmental studies or wilderness mineral investigations.

Hydrologic Investigations Atlases are multicolored or black-andwhite maps on topographic or planimetric bases presenting a wide range of geohydrologic data of both regular and irregular areas; the principal scale is $1: 24,000$, and regional studies are at $1: 250,000$ scale or smaller.

\section{Catalogs}

Permanent catalogs, as well as some others, giving comprehensive listings of U.S. Geological Survey publications are available under the conditions indicated below from USGS Map Distribution, Box 25286, Building 810, Denver Federal Center, Denver, CO 80225. (See latest Price and Availability List.)

"Publications of the Geological Survey, 1879-1961" may be purchased by mail and over the counter in paperback book form and as a set microfiche.

"Publications of the Geological Survey, 1962-1970" may be purchased by mail and over the counter in paperback book form and as a set of microfiche.

"Publications of the U.S. Geological Survey, 1971-1981" may be purchased by mail and over the counter in paperback book form (two volumes, publications listing and index) and as a set of microfiche.

Supplements for $1982,1983,1984,1985,1986$, and for subsequent years since the last permanent catalog may be purchased by mail and over the counter in paperback book form.

State catalogs, "List of U.S. Geological Survey Geologic and Water-Supply Reports and Maps For (State)," may be purchased by mail and over the counter in paperback booklet form only.

"Price and Availability List of U.S. Geological Survey Publications," issued annually, is available free of charge in paperback booklet form only.

Selected copies of a monthly catalog "New Publications of the U.S. Geological Survey" is available free of charge by mail or may be obtained over the counter in paperback booklet form only. Those wishing a free subscription to the monthly catalog "New Publications of the U.S. Geological Survey" should write to the U.S. Geological Survey, 582 National Center, Reston, VA 22092.

Note.-Prices of Government publications listed in older catalogs, announcements, and publications may be incorrect. Therefore, the prices charged may differ from the prices in catalogs, announcements, and publications. 